Pacific Northwest

National Laboratory

Operated by Battelle for the

U.S. Department of Energy

\title{
Waste Form Release Data Package for the 2001 Immobilized Low-Activity Waste Performance Assessment
}

\author{
B. P. McGrail \\ J. P. Icenhower \\ P. F. Martin \\ H. T. Schaef \\ M. J. O'Hara \\ E. A. Rodriguez \\ J. L. Steele
}

February 2001

Prepared for the U.S. Department of Energy

under Contract DE-AC06-76RL01830 


\title{
DISCLAIMER
}

This report was prepared as an account of work sponsored by an agency of the United States Government. Neither the United States Government nor any agency thereof, nor Battelle Memorial Institute, nor any of their employees, makes any warranty, expressed or implied, or assumes any legal liability or responsibility for the accuracy, completeness, or usefulness of any information, apparatus, product, or process disclosed, or represents that its use would not infringe privately owned rights. Reference herein to any specific commercial product, process, or service by trade name, trademark, manufacturer, or otherwise does not necessarily constitute or imply its endorsement, recommendation, or favoring by the United States Government or any agency thereof, or Battelle Memorial Institute. The views and opinions of authors expressed herein do not necessarily state or reflect those of the United States Government or any agency thereof.

\section{PACIFIC NORTHWEST NATIONAL LABORATORY operated by \\ BATTELLE MEMORIAL INSTITUTE for the \\ UNITED STATES DEPARTMENT OF ENERGY under Contract DE-AC06-76RLO 1830}

\author{
Printed in the United States of America
}

Available to DOE and DOE contractors from the Office of Scientific and Technical Information, P.O. Box 62, Oak Ridge, TN 37831; prices available from $(615) 576-8401$.

Available to the public from the National Technical Information Service, U.S. Department of Commerce, 5285 Port Royal Rd., Springfield, VA 22161 
PNNL-13043, Rev. 2

\title{
Waste Form Release Data Package for the 2001 Immobilized Low-Activity Waste Performance Assessment
}

\author{
B. P. McG rail \\ J. P. Icenhower \\ P. F. Martin \\ H. T. Schaef \\ M. J. O'Hara \\ E. A. Rodriguez \\ J. L. Steele
}

January 2001

Prepared for

the U.S. D epartment of Energy under Contract DE-AC06-76RLO 1830

Pacific Northwest National Laboratory

Richland, Washington 99352 



\section{SUMMARY}

This data package documents the experimentally derived input data on the representative waste glasses LAWABP1 and HLP-31 that will be used for simulations of the immobilized lowactivity waste disposal system with the Subsurface Transport Over Reactive Multiphases (STORM) code. The STORM code will be used to provide the near-field radionuclide release source term for a performance assessment to be issued in March of 2001. Documented in this data package are data related to 1) kinetic rate law parameters for glass dissolution, 2) alkali-H ion exchange rate, 3) chemical reaction network of secondary phases that form in accelerated weathering tests, and 4) thermodynamic equilibrium constants assigned to these secondary phases. The kinetic rate law and $\mathrm{Na}^{+}-\mathrm{H}^{+}$ion exchange rate were determined from single-pass flow-through experiments. Pressurized unsaturated flow and vapor hydration experiments were used for accelerated weathering or aging of the glasses. The majority of the thermodynamic data were extracted from the thermodynamic database package shipped with the geochemical code EQ3/6. However, several secondary reaction products identified from laboratory tests with prototypical LAW glasses were not included in this database, nor are the thermodynamic data available in the open literature. One of these phases, herschelite, was determined to have a potentially significant impact on the release calculations and so a solubility product was estimated using a polymer structure model developed for zeolites.

Although this data package is relatively complete, final selection of ILAW glass compositions has not been done by the waste treatment plant contractor. Consequently, revisions to this data package to address new ILAW glass formulations are to be regularly expected. 



\section{CONTENTS}

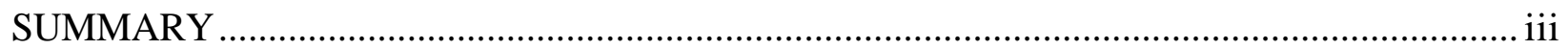

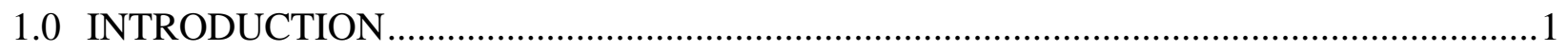

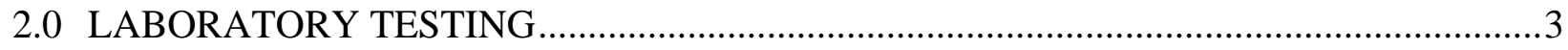

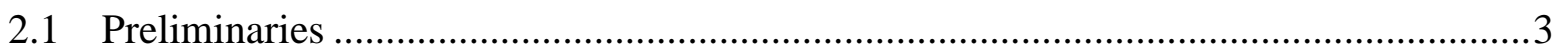

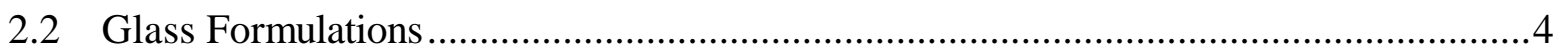

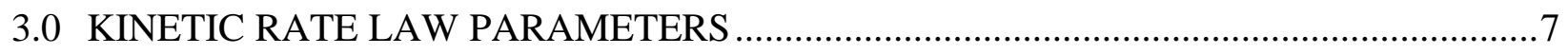

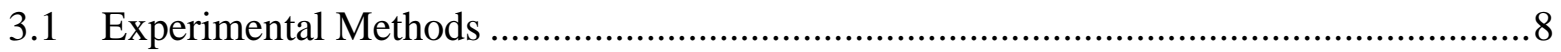

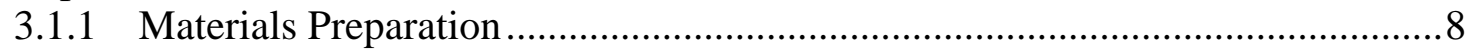

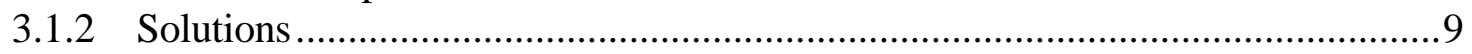

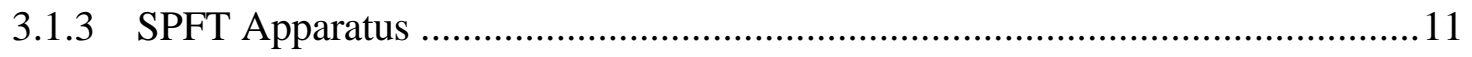

3.1.4 Dissolution Rate and Error Calculations ...................................................... 12

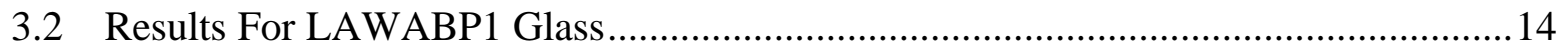

3.2.1 Achievement of Steady-State and Consistency of Results.............................15

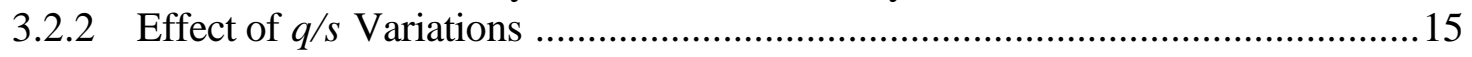

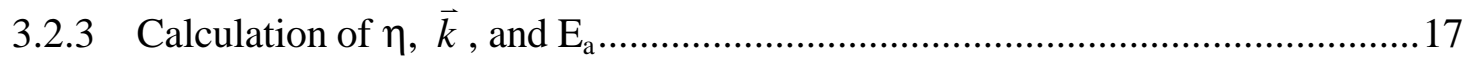

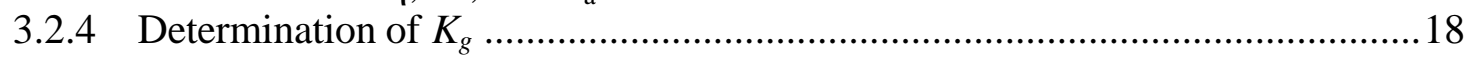

3.2.4.1 Solutions Doped with $\mathrm{Si}$.............................................................. 18

3.2.4.2 Solutions Doped with Al..............................................................21

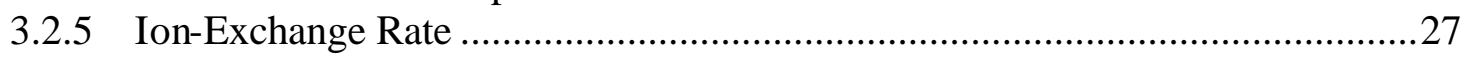

3.2.6 Effects of Humic and Fulvic Acid..........................................................28

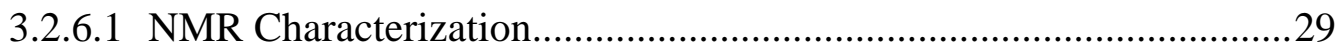

3.2.6.2 Dissolution Rate Results .................................................................. 30

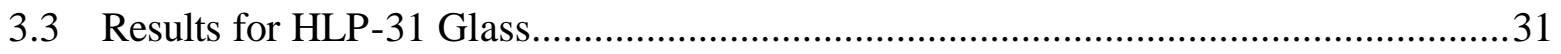

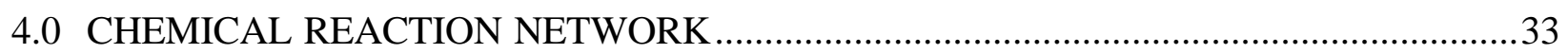

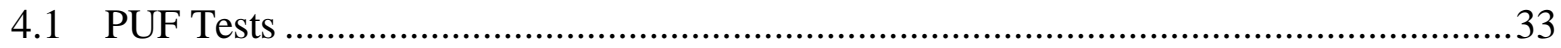

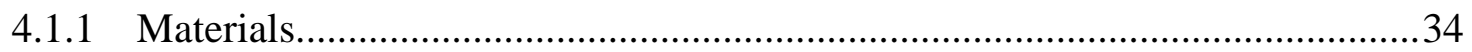

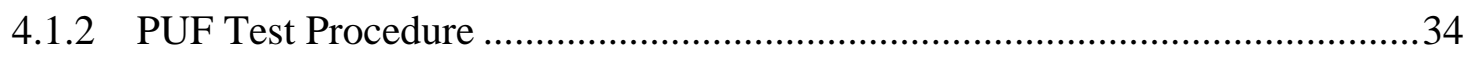

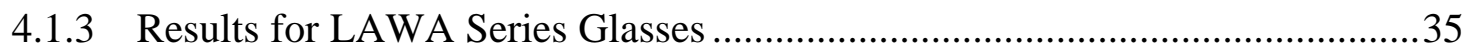

4.1.3.1 Humic and Fulvic Acid Solutions ........................................................36

4.1.3.2 LAWABP1 Water Mass Distribution ......................................................37

4.1.3.3 Solid Phase Analyses ...........................................................................37

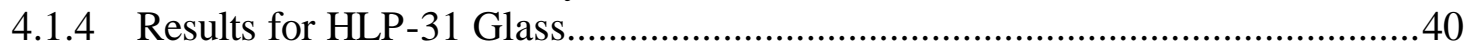

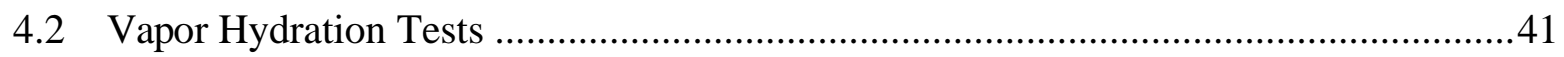

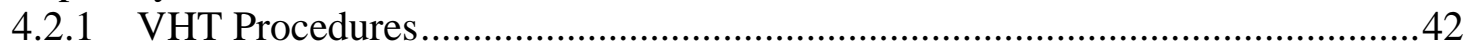

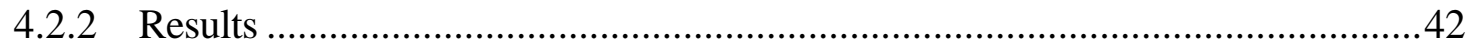

4.2.3 Results for Other ILAW Glasses...............................................................43

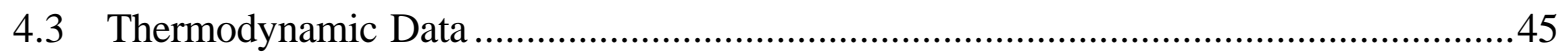

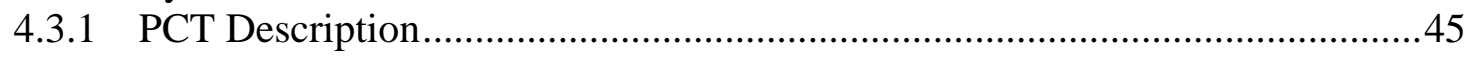

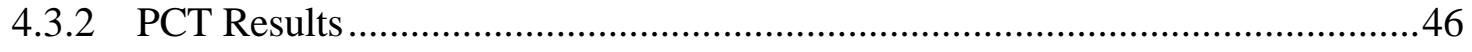

4.3.3 Modeling With EQ3/6 ..........................................................................46

4.3.4 Solubility Product for Herschelite .................................................................... 47 
5.0 CONCLUSION

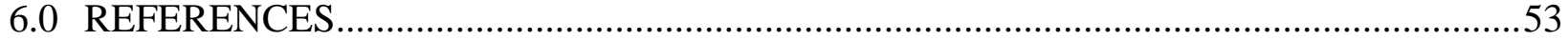

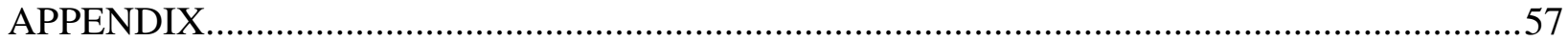




\section{$\underline{\text { LIST OF TABLES }}$}

1. Overview of Test Methods Discussed in this Data Package ...........................................2

2. Composition (Mass\%) of Selected ILAW Glasses.........................................................5

3. Composition of Solutions Used in SPFT Experiments .................................................... 10

4. Comparison of Ion-Activity Product Regressed From SPFT Tests with

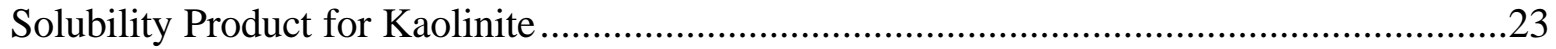

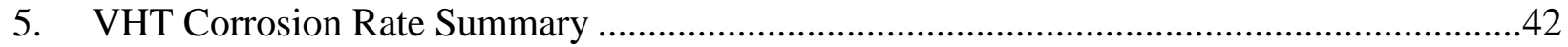

6. Alteration Products on VHT Samples as Determined by XRD ........................................43

7. Secondary Phase Reaction Network for LAWABP1 Glass...............................................48

8. Thermochemical Data used in the Calculations ............................................................50

9. Summary of Best Estimate Rate Law Parameters for LAWABP1 and HLP-31 Glasses at $15^{\circ} \mathrm{C}$ 



\section{LIST OF FIGURES}

1. High Magnification SEM Image of Nitric Acid Etched HLP-31 Glass .............................6

2. Schematic of the Single Pass Flow-Through (SPFT) Apparatus ......................................11

3. Boron Concentration Versus Time for the Four Temperatures Investigated........................15

4. Effect of Variation in the Ratio of Flow Rate, $q$, to Sample Surface Area, $S$, on Glass Dissolution Rate

5. Effect of Variation in the Ratio of Flow Rate, $q$, to Sample Surface Area, $S$, on Glass Dissolution Rate at Various Temperatures

6. $\log _{10}$ Dissolution Rate Versus Temperature Corrected $\mathrm{pH}$ for LAWABP1 Glass .17

7. Plot of Dissolution Rates Based on B and Na Versus the Activity of Silicic Acid at 26 and $40^{\circ} \mathrm{C}$

8. Plot of Dissolution Rate with Respect to B and Na Versus Silicic Acid Activity at 70 and $90^{\circ} \mathrm{C}$.

9. $\log _{\mathrm{e}} K_{g}$ Versus $1 / \mathrm{T}$ for LAWABP1 Glass

10. Plot of Dissolution Rate Versus Activity of Aluminate Ion for LAWABP1 Glass, $40^{\circ} \mathrm{C}$.....22

11. Plot of the $\log _{10}$ of Silicic Acid and Aluminate Ion Activities at 40, 70, and $90^{\circ} \mathrm{C} \ldots \ldots \ldots \ldots . . . .22$

12. Plot of Dissolution Rate at 40 and $90^{\circ} \mathrm{C}$ Versus 1:1 Mixed Al-Si Activity Product.

13. Plot of Dissolution Rate at 40 and $90^{\circ} \mathrm{C}$ Versus a Mixed Al-Si Activity Product Based on Bulk Glass Stoichiometry

14. Plots of Dissolution rate at $90^{\circ} \mathrm{C}$ Versus the Two Competing Al-Si Activity Product Schemes .....

15. Plot of Dissolution Rate Versus Activity of Silicic Acid for a Boroaluminosilicate Glass at $25^{\circ} \mathrm{C}$

16. Sodium-H Exchange Rate Versus Reciprocal Temperature for LAWABP1 Glass

17. MAS-NMR Spectra of Aldrich Humic Acid Used in SPFT Experiments

18. Dissolution Rate (Based on $\mathrm{B}, \mathrm{Al}$, or $\mathrm{Na}$ ) Versus Time for Experiments With and Without Humic Acid (A) and Fulvic Acid (B).

19. Dissolution Rate of HLP-31 Glass Versus Activity of Silicic Acid for Conditions of $\mathrm{pH}=9, \mathrm{~T}=26^{\circ} \mathrm{C}$.

20. Forward Reaction Rate as a Function of Temperature and Solution $\mathrm{pH}$ for a Wide Variety of Borosilicate Glasses.

21. Picture of PUF System Hardware (Patent \#5974859)

22. Computer Monitored Test Metrics From PUF Tests with LAWA Series of Glasses.

23. Normalized Release Rate for Selected Elements in PUF Tests with LAWA Series of Glasses. 
24. Water Mass Distribution in Reacted Solids From PUF Test with LAWABP1 Glass

25. Optical Photos of LAWABP1 Glass Samples S4 and S9 After $190 \mathrm{~d}$ of Reaction in PUF Test at $99^{\circ} \mathrm{C}$ and $2 \mathrm{~mL} / \mathrm{d}$ Flow Rate .38

26. XRD Analyses of PUF Reacted LAWABP1 Glass Samples ...........................................38

27. SEM Photos of Reacted LAWABP1 Glass Grains From Sample S9 ................................39

28. Kaolinite Crystals Found on PUF Reacted LAWABP1 Glass Sample S11 .......................39

29. Aluminosilicate Phase Shown in Cross-Section in PUF Reacted LAWABP1 Sample S1 ...39

30. Computer Monitored Test Metrics From PUF Test with HLP-31 Glass............................40

31. Normalized Release Rate for Selected Elements in PUF Test with HLP-31 Glass .............40

32. Schematic of Apparatus for conducting Vapor-phase Hydration Test ...............................41

33. Radial Distribution Plot of $200^{\circ} \mathrm{C}$ VHT Corrosion Rates for HLP Series of ILAW Glasses.....

34. Cumulative Distribution Plot of $200^{\circ} \mathrm{C}$ VHT Corrosion Rates for HLP Series of ILAW Glasses.

35. PCT Data for Selected ILAW Glasses

36. Comparison of PCT Solution Concentration Data with the Solution Composition Calculated with the EQ3/6 Code (lines)

37. Predicted Paragenetic Sequence of Alteration Phases Formed During the Reaction of LAWABP1 Glass in Deionized Water 


\section{$\underline{\text { ACRONYMS }}$}

ANL Argonne National Laboratory

ASTM American Society for Testing and Materials

BET Brunauer, Emmett, and Teller surface area measurement

BNFL British Nuclear Fuels Limited

DIW deionized water

DOE Department of Energy

DWPF Defense Waste Processing Facility

EDXS energy dispersive $\mathrm{x}$-ray spectroscopy

HLW high-level waste

ICP-OES inductively coupled plasma optical emission spectrometry

ICP-MS inductively coupled plasma mass spectrometry

ILAW immobilized low activity waste

MCC Materials Characterization Center

M\&TE materials and test equipment

ORP Office of River Protection

PA performance assessment

PCT product consistency test

PNNL Pacific Northwest National Laboratory

PUF pressurized unsaturated flow

QA quality assurance

QAPD quality assurance program documents

$\mathrm{RH} \quad$ relative humidity

SAED selected area electron diffraction

SEM scanning electron microscope

SPFT single-pass flow through (glass test)

STORM Subsurface Transport Over Reactive Multiphases (computer code)

S/V surface area-to-solution volume ratio

TEM transmission electron microscope

THAM tris hydroxymethyl aminomethane

TST transition state theory

VHT vapor hydration test (glass test)

XRD X-ray diffraction 


\subsection{INTRODUCTION}

The Hanford Low-Activity Tank Waste Disposal Program is planning to issue a performance assessment (PA) in March of 2001. The major goals of the performance assessment activity are to:

- support the design of disposal facilities

- provide the technical basis for the Department of Energy (DOE) to authorize construction of disposal facilities

- obtain approval to dispose of immobilized low-activity Hanford tank waste in those facilities

- provide a technical basis for final closure of the disposal facilities.

A critical component of the PA will be to provide quantitative estimates of radionuclide release rates from the engineered portion of the disposal facilities (source term). Computer models are essential for this purpose because impacts on groundwater resources must be projected out to time periods of 10,000 y and longer. Details on the recommended technical strategy for developing this source term have been published [1] and have undergone review by an international panel of experts. This data package was developed from a direct implementation of that technical strategy.

The computer model selected for modeling the radionuclide source-term is the Subsurface Transport Over Reactive Multiphases (STORM) code [2]. The required inputs to this code will be derived from literature sources and from laboratory experiments with ILAW glasses. This report, therefore, functions to document the input data that will be used for STORM simulations. The STORM code requires input of two main general classifications of data: 1) multiphase flow, and 2) reactive transport. Multiphase flow input is defined in the near-field hydraulic properties data package or the far-field hydraulic properties data package [3]. Experimentally derived input related to conducting reactive transport calculations is defined within this data package.

Laboratory testing provides the majority of the key input data required to assess the longterm performance of ILAW glasses with the STORM code. Test data from four principal methods, called out by McGrail et al [1], are discussed in this data package including the single-pass flow-through test (SPFT), pressurized unsaturated flow (PUF) test, product consistency test (PCT), and vapor hydration test (VHT). The different test methods focus on different aspects of the glass corrosion process. Linkages between the test methods, their principal function, and the 
data they provide for modeling are provided in Table 1. The interested reader is encouraged to consult reference [1] for additional details regarding these test methods and their use in evaluating long-term glass performance.

Table 1. Overview of Test Methods Discussed in this Data Package

\begin{tabular}{|l|l|l|l|l|}
\hline $\begin{array}{c}\text { Test } \\
\text { Method }\end{array}$ & $\begin{array}{l}\text { Temperature } \\
\text { Range }\end{array}$ & Duration & \multicolumn{1}{|c|}{ Data Provided } & \multicolumn{1}{|c|}{ Purpose } \\
\hline SPFT & $25-90^{\circ} \mathrm{C}$ & $14-28 \mathrm{~d}$ & $\begin{array}{l}\text { Dissolution rate as a function } \\
\text { of temperature, pH, and solu- } \\
\text { tion composition }\end{array}$ & $\begin{array}{l}\text { Parameterization of kinetic } \\
\text { rate law for glass dissolu- } \\
\text { tion }\end{array}$ \\
\hline PUF & $40-100^{\circ} \mathrm{C}$ & $\begin{array}{l}\text { Months } \\
\text { to years }\end{array}$ & $\begin{array}{l}\text { Effluent chemical composi- } \\
\text { tion and dissolution rate as a } \\
\text { function of temperature and } \\
\text { flow rate, secondary phases, } \\
\text { hydraulic property changes. }\end{array}$ & $\begin{array}{l}\text { Highly accelerated test for } \\
\text { glass screening, secondary } \\
\text { phases for STORM reaction } \\
\text { network, validation of } \\
\text { STORM code. }\end{array}$ \\
\hline PCT & $20-100^{\circ} \mathrm{C}$ & $\begin{array}{l}\text { Weeks } \\
\text { to years }\end{array}$ & $\begin{array}{l}\text { Solution composition and } \\
\text { dissolution rate as a function } \\
\text { of S/V ratio and temperature, } \\
\text { secondary phases. }\end{array}$ & $\begin{array}{l}\text { Glass screening, secondary } \\
\text { phases for STORM reaction } \\
\text { network, calibration of reac- } \\
\text { tion network with EQ3/6 } \\
\text { code. }\end{array}$ \\
\hline VHT & $70-300^{\circ} \mathrm{C}$ & $\begin{array}{l}\text { Days to } \\
\text { years }\end{array}$ & $\begin{array}{l}\text { Rough estimate of dissolu- } \\
\text { tion rate as a function of } \\
\text { temperature, secondary } \\
\text { phases }\end{array}$ & $\begin{array}{l}\text { Highly accelerated test for } \\
\text { glass screening, secondary } \\
\text { phases for STORM reaction } \\
\text { network. Cannot be used } \\
\text { for evaluating glass corro- } \\
\text { sion models. }\end{array}$ \\
\hline
\end{tabular}




\subsection{LABORATORY TESTING}

Laboratory testing of a large number of prototypic ILAW glasses has been performed. However, because of constraints on laboratory resources and computation time required to run complex reactive transport simulations with STORM, the source-term calculations for the 2001 ILAW PA will be limited to one representative glass formulation, LAWABP1, and one glass formulation (HLP-31) intended to represent a bounding glass formulation in terms of waste loading and product durability. Additional supporting data on a variety of other ILAW glass formulations will be provided to demonstrate that LAWABP1 and HLP-31 glasses represent reasonable bounds on the performance of the ILAW glass product to be eventually produced at Hanford, based on the current understanding of the tank waste processing flow sheet and vitrification plant design.

\section{$2.1 \quad$ PRELIMINARIES}

The interested reader should consult McGrail et al. [1] for a thorough discussion of how each of the tests described in this data package fit into an overall strategy to evaluate the long-term performance of ILAW glasses. All testing work reported in this data package was conducted in accordance with PNNL's Quality Management System Description and associated Quality Assurance Program Documents (QAPD), which are maintained electronically as part of the Standards Based Management System or under an equivalent QA Program at Argonne National Laboratory (ANL). All instrument calibrations and materials are traceable, test procedures and associated training activities are documented in detail, and test methods comply with established plans and procedures. Computer Software and Database Control procedures are being followed for data analysis software being used to store, sort, and reduce data.

All staff members contributing to this data package received proper technical and quality assurance training in accordance with QAPD Training and Qualification for Staff. Equipment is either calibrated periodically or at the time of use and the calibration status of each piece of equipment is documented through a Material and Test Equipment sheet (M\&TE), which is maintained as a part of the QA file. The M\&TE sheets specify the required calibration methods, us ually include a calibration procedure, and document the status of the equipment. All equipment requiring calibration prior to its use will be so labeled. 
Documented procedures were used for sample preparation, test performance, and sample analysis. Operations not specifically covered in a documented procedure were documented in a Scientific Notebook. Comments regarding the test performance and test activities are contained in a Scientific Notebook associated with each test.

\subsection{GLASS FORMULATIONS}

The test results presented in the following sections will reference seven different ILAW glass compositions. These are provided in Table 2 for reference. It should be noted that LD6-5412 glass is a "high-temperature" glass formulation and has been included here because of the long history of studies with this glass. LRM-1 is an analytical reference standard glass developed at ANL [4]. LAWA23, LAWA33, LAWABP1, and HLP-10 are prototypic of ILAW glasses that were under development by BNFL, Inc. for the U.S. DOE Office of River Protection. HLP-31 glass is a higher waste loading formulation developed as part of a statistically designed matrix of $56 \mathrm{ILAW}$ glasses. The glasses varied the concentrations of $\mathrm{SiO}_{2}, \mathrm{Al}_{2} \mathrm{O}_{3}, \mathrm{~B}_{2} \mathrm{O}_{3}, \mathrm{Fe}_{2} \mathrm{O}_{3}, \mathrm{TiO}_{2}$, $\mathrm{ZnO}, \mathrm{ZrO}_{2}, \mathrm{MgO}$, and $\mathrm{Na}_{2} \mathrm{O}$ across a wide composition range that covers, with high probability, the expected processing composition range for candidate ILAW glasses. For details on the specific glass compositions involved, please see reference [5].

The glasses were prepared by mixing measured amounts of dried reagent-grade chemicals (oxides, fluorides, iodides, and sulphides) in an agate mill. The mixtures were melted in a $\mathrm{Pt}$ $(10 \%) \mathrm{Rh}$ crucible and the molten glass was poured onto a cool stainless steel plate. Each glass was then subjected to heat treatment by placing the glass in a preheated oven at $930^{\circ} \mathrm{C}$ and then cooling at $21^{\circ} \mathrm{C} / \mathrm{hr}$. This cooling rate is consistent with a computed thermal profile for a $1.2 \mathrm{~m} \mathrm{x}$ $1.2 \mathrm{~m} \times 1 \mathrm{~m}$ container that was the design being considered for LAW. The container design has since been modified to a cylinder of $1.2 \mathrm{~m}$ diameter x $2.3 \mathrm{~m}$ tall. Microstructural examination of LAWABP1 glass in a transmission electron microscope showed no evidence of devitrification or phase separation from the heat treatment. 
Table 2. Composition (Mass\%) of Selected ILAW Glasses

\begin{tabular}{|c|c|c|c|c|c|c|c|}
\hline Oxide & LD6-5412 & LRM-1 & LAWA23 & LAWA33 & LAWABP1 & HLP-10 & HLP-31 \\
\hline $\mathrm{Al}_{2} \mathrm{O}_{3}$ & 12.000 & 10.000 & 9.700 & 11.970 & 10.000 & 7.150 & 4.000 \\
\hline $\mathrm{B}_{2} \mathrm{O}_{3}$ & 5.000 & 8.000 & 4.320 & 8.850 & 9.250 & 8.000 & 12.000 \\
\hline $\mathrm{CaO}$ & 4.000 & 0.500 & 4.460 & & & 0.010 & 0.010 \\
\hline $\mathrm{CdO}$ & & 0.200 & & & & & \\
\hline $\mathrm{Cl}$ & 0.350 & 0.800 & 0.360 & 0.580 & 0.580 & 0.28 & 0.320 \\
\hline $\mathrm{Cr}_{2} \mathrm{O}_{3}$ & 0.040 & 0.200 & 0.010 & 0.020 & 0.020 & 0.080 & 0.090 \\
\hline $\mathrm{Cs}_{2} \mathrm{O}$ & 0.150 & & & & & & \\
\hline F & 0.290 & 1.000 & 0.040 & 0.040 & 0.040 & 0.010 & 0.010 \\
\hline $\mathrm{Fe}_{2} \mathrm{O}_{3}$ & 0.003 & 1.000 & 7.430 & 5.770 & 2.500 & 5.630 & 3.360 \\
\hline I & 0.130 & 0.002 & 0.057 & & & & \\
\hline $\mathrm{K}_{2} \mathrm{O}$ & 1.460 & 1.500 & 2.310 & 3.100 & 2.200 & 0.420 & 0.470 \\
\hline $\mathrm{La}_{2} \mathrm{O}_{3}$ & & 0.009 & & & 2.000 & & \\
\hline $\mathrm{Li}_{2} \mathrm{O}$ & & 0.100 & 2.080 & & & & \\
\hline $\mathrm{MgO}$ & 0.003 & 0.100 & 2.080 & 1.990 & 1.000 & 1.530 & 0.920 \\
\hline $\mathrm{MnO}$ & 0.002 & 0.100 & & & & & \\
\hline $\mathrm{MoO}_{3}$ & 0.150 & 0.100 & & & & & \\
\hline $\mathrm{Na}_{2} \mathrm{O}$ & 20.000 & 20.000 & 20.000 & 20.000 & 20.000 & 20.450 & 23.00 \\
\hline $\mathrm{NiO}$ & & 0.100 & & & & & \\
\hline $\mathrm{P}_{2} \mathrm{O}_{5}$ & 0.190 & 0.500 & 0.050 & 0.080 & 0.080 & 0.060 & 0.060 \\
\hline $\mathrm{PbO}_{2}$ & & 0.100 & & & & & \\
\hline $\mathrm{ReO}_{2}$ & & & 0.098 & & & 0.010 & 0.010 \\
\hline $\mathrm{SO}_{3}$ & 0.210 & 0.200 & 0.040 & 0.100 & 0.100 & 0.070 & 0.080 \\
\hline $\mathrm{SeO}_{2}$ & & & 0.050 & & & & \\
\hline $\mathrm{SiO}_{2}$ & 55.912 & 54.370 & 40.520 & 38.250 & 41.890 & 50.160 & 52.000 \\
\hline $\mathrm{SrO}$ & 0.110 & & & & & & \\
\hline $\mathrm{TiO}_{2}$ & & 0.100 & & 2.490 & 2.490 & 3.060 & 1.830 \\
\hline $\mathrm{ZnO}$ & & & 3.340 & 4.270 & 2.600 & 1.530 & 0.920 \\
\hline $\mathrm{ZrO}_{2}$ & & 1.000 & 3.050 & 2.490 & 5.250 & 1.530 & 0.920 \\
\hline
\end{tabular}

However, both TEM and high magnification SEM examination of HLP-31 showed evidence of liquid-liquid phase separation. Figure 1 shows an SEM photo after HLP-31 glass had been immersed in $6 \mathrm{M}$ nitric acid for 2 minutes. As is obvious from the figure, the glass is dissolving in a very non- uniform manner, consistent with a glass having two immiscible phases. Energy dispersive x-ray spectroscopy (EDXS) did not reveal any distinct compositional differences 
among the regions but this may be a consequence of beam penetration into the underlying bulk glass or because the regions are borate rich/depleted. Boron cannot be detected with the EDXS unit on our SEM. The phase separation observed with HLP-31 glass has significant impacts on its behavior in dissolution tests, as will be discussed in Sections 3.3 and 4.1.4.

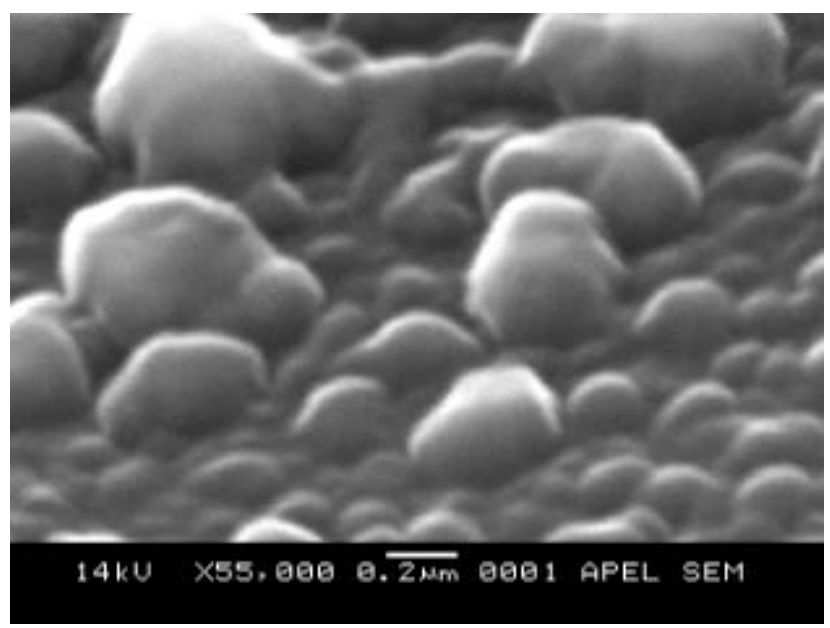

Figure 1. High Magnification SEM Image of Nitric Acid Etched HLP-31 Glass 


\subsection{KINETIC RATE LAW PARAMETERS}

To predict the long-term fate of glass in the subsurface over the period of regulatory concern, a mathematical model that describes glass reactivity is needed. Over the last few decades, a general rate equation has been fashioned to describe the dissolution of glass (and more ordered materials) into aqueous solution. As described below, the equation is based upon the Transition State Theory of chemical kinetics, in which the overall reaction rate is governed by the slowest elementary reaction. Elementary reactions have simple stoichiometry and can be combined as an overall reaction. In many cases, the elementary reactions can only be inferred. As an example of the elementary reaction, consider the dissolution of $\mathrm{SiO}_{2}$ polymorphs to form silicic acid:

$$
\mathrm{SiO}_{2}(\text { solid })+2 \mathrm{H}_{2} \mathrm{O} \Leftrightarrow \mathrm{SiO}_{2} * 2 \mathrm{H}_{2} \mathrm{O}^{\ddagger} \rightarrow \mathrm{H}_{4} \mathrm{SiO}_{4}(\text { aqueous })
$$

in which $\mathrm{SiO}_{2} * 2 \mathrm{H}_{2} \mathrm{O}^{\ddagger}$ represents an activated complex of unknown stoichiometry. Note that the reactants and the activated complex in Equation (1) are linked by a double-headed arrow symbolizing that the reaction is reversible such that the latter can back react to form the former. Decay of the activated complex to form the product (silicic acid) is irreversible in the TST formulation and is symbolized as a uni-directional arrow.

With these assumptions, a general equation describing the rate of reaction as a function of $\mathrm{pH}$, temperature, saturation state of the system, and the activities of rate enhancing or inhibiting species [6] has been proposed:

$$
k=\vec{k} a_{\mathrm{H}^{+}}^{-\eta} \exp \left(\frac{-E_{a}}{\mathrm{RT}}\right)\left[1-\left(\frac{Q}{K_{g}}\right)^{\sigma}\right] \prod_{j} a_{j}^{\eta_{j}}
$$

where $k=$ dissolution rate, $\mathrm{g} \mathrm{m}^{-2} \mathrm{~d}^{-1}$

$\vec{k}=$ intrinsic rate constant, $\mathrm{g} \mathrm{m}^{-2} \mathrm{~d}^{-1}$

$a_{\mathrm{H}^{+}}=$hydrogen ion activity

$a_{j}=$ activity of the $j^{\text {th }}$ aqueous species that acts as an inhibitor or as a catalyst

$E_{a}=$ activation energy, $\mathrm{kJ} / \mathrm{mol}$

$\mathrm{R}=$ gas constant, $\mathrm{kJ} \mathrm{mol}^{-1} \cdot \mathrm{K}^{-1}$

$\mathrm{T}$ = temperature, $\mathrm{K}$

$Q \quad$ = ion activity product

$K_{g} \quad$ = pseudoequilibrium constant for glass

$\eta \quad$ power law coefficient

$\sigma \quad=$ Temkin coefficient. 
Although there are a number of issues regarding the applicability of Equation (2) for modeling glass dissolution, McGrail et al. [1] conclude that this rate law currently “...best describes the majority of the experimental data that has been gathered over 35 years of studying glass/water reaction processes." Consequently, parameterization of this equation is required to conduct source-term calculations with the STORM code. Because the disposal system temperature is a known constant, the determination of five parameters; $\vec{k}, \mathrm{E}_{\mathrm{a}}, \eta, \sigma, K_{g}$, is required for each glass

formulation (neglecting the $\prod_{j} a_{j}^{\eta_{j}}$ term). The ion activity product $(Q)$ is a variable and must be computed with STORM as a function of time and space for the disposal system [1]. Lasaga [7] convincingly argues that $\sigma$ should be ignored in the above equation because any value where $\sigma \neq 1$ is inconsistent with transition state theory. Consequently, $\sigma=1$ is assumed for this work, thus eliminating $\sigma$ as an unknown parameter in the rate law.

\section{$3.1 \quad$ EXPERIMENTAL METHODS}

The dissolution kinetics of LAWABP1 and HLP-31 glass compositions was quantified through the use of single-pass flow-through (SPFT) tests. The SPFT test is an open system test where a solution at a known flow rate and constant temperature flows through a reaction cell that contains the sample. The configuration precludes recirculation of the effluent and so makes a "single-pass" through the reaction cell. Many different SPFT apparatuses have been developed, but these can all be classified as three basic types: 1) well-mixed batch, 2) packed bed, and 3) fluidized bed. The well-mixed batch type of apparatus was used for all test data reported here. The usefulness of SPFT experiments stems from the system reaching a steady-state condition between the glass and the aqueous solution. Steady-state conditions ensure that the system is maintained at constant chemical affinity and the effluent is at a constant value of $\mathrm{pH}$. By manipulating one experimental parameter at a time, such as temperature, flow-rate, $\mathrm{pH}$, or the concentration of additives, the parameters within Equation (2) can be isolated and quantified [8-10].

\subsubsection{Materials Preparation}

Crushing glass in a ceramic ball mill produced the samples of glass powders used in this study. The crushed glass was then sieved to separate the powders into a variety of size fractions; in this study, only the $<100,>200$ mesh (149 to $75 \mu$ m diameter) size fraction was used. The 
powdered sample was then sonicated in deionized water (DIW) and rinsed in ethanol to remove any adhering particles outside the desired size fraction. After drying in a $90^{\circ} \mathrm{C}$ oven for several hours, the powder was kept in a desiccator until used in an experiment. The specific surface area of the glass samples was estimated based on the following geometric formula [8]:

$$
s=\frac{3 m}{\rho r}
$$

where $m$ is the mass of glass particles (g), $\rho$ is the glass density $\left(\mathrm{g} \mathrm{m}^{-3}\right)$, and $r$ is the average particle radius in meters. Applying this formula for LAWABP1 and HLP-31 glasses in this size fraction yields a specific surface area of $0.020 \pm 0.003 \mathrm{~m}^{2} / \mathrm{g}$. McGrail et al. [11] discuss experiments with these glasses conclusively showing that the surface area estimated from Equation (3) more accurately represents the true surface area in dissolution tests than the surface area determined by BET methods [12].

\subsubsection{Solutions}

Seven different solutions were used to control the $\mathrm{pH}$ during the experiments and are listed in Table 3. Acid solutions ( $\mathrm{pH}=2,4)$ were prepared by adding $\mathrm{HNO}_{3}$ to deionized water (DIW). Neutral to slightly basic solutions ( $\mathrm{pH}=7,8,9$, and 10) were made by adding small amounts of the organic THAM (tris hydroxymethyl aminomethane) buffer to DIW and then adding minor concentrations of $\mathrm{HNO}_{3}$ to bring the solution to the desired $\mathrm{pH}$ value. Alkaline solutions $(\mathrm{pH}=$ 11) were prepared by adding $\mathrm{LiCl}$ and $\mathrm{LiOH}$ to DIW. Table 3 also gives the change in $\mathrm{pH}$ with respect to the temperature of the experiment, as calculated with the EQ3NR geochemical code [8]. As one can see from Table 3, the in-situ $\mathrm{pH}$ of the experiment can change by as much as 1.5 $\mathrm{pH}$ units over the temperature interval of 23 to $90^{\circ} \mathrm{C}$.

Aliquots of all input solutions used in this study were analyzed by ICP-OES (inductively coupled plasma optical emission spectroscopy) methods to determine the background concentration of elements of interest ( $\mathrm{Al}, \mathrm{B}, \mathrm{Mg}, \mathrm{K}, \mathrm{Si}, \mathrm{Na}$ ). In all cases (except the humic acid solution; see Section 3.2.6), the background concentrations of elements were below their respective detection thresholds. 
Table 3. Composition of Solutions Used in SPFT Experiments. TRIS = THAM-based buffer. Solution $\mathrm{pH}$ values above $23^{\circ} \mathrm{C}$ were calculated with EQ3NR Code V7.2b database.

\begin{tabular}{clrrrr} 
Solution \# & \multicolumn{1}{c}{ Composition } & $\mathrm{pH} 23^{\circ} \mathrm{C}$ & $\mathrm{pH} 40^{\circ} \mathrm{C}$ & $\mathrm{pH} 70^{\circ} \mathrm{C}$ & $\mathrm{pH} 90^{\circ} \mathrm{C}$ \\
\hline 1 & $0.01 \mathrm{M} \mathrm{HNO}_{3}$ & 2.01 & 2.04 & 2.07 & 2.11 \\
2 & $0.0001 \mathrm{M} \mathrm{HNO}_{3}$ & 3.66 & 3.71 & 3.71 & 3.71 \\
3 & $0.01 \mathrm{M} \mathrm{TRIS}^{2} 0.0093 \mathrm{M} \mathrm{HNO}_{3}$ & 7.13 & 6.53 & 5.87 & 5.50 \\
4 & $0.01 \mathrm{M} \mathrm{TRIS}+0.0059 \mathrm{M} \mathrm{HNO}_{3}$ & 8.08 & 7.54 & 6.88 & 6.52 \\
5 & $0.05 \mathrm{M} \mathrm{TRIS}+0.0079 \mathrm{M} \mathrm{HNO}_{3}$ & 8.97 & 8.44 & 7.78 & 7.42 \\
6 & $0.05 \mathrm{M} \mathrm{TRIS}$ & 9.65 & 9.38 & 8.87 & 8.52 \\
7 & $0.01 \mathrm{M} \mathrm{LiCl}+0.0107 \mathrm{LiOH}$ & 11.07 & 10.94 & 10.49 & 10.12
\end{tabular}

For select experiments, we added $\mathrm{Al}, \mathrm{Si}$, or both to input solutions. Aluminum was added in the form of water soluble $\mathrm{Al}\left(\mathrm{NO}_{3}\right)_{3} \cdot 9 \mathrm{H}_{2} \mathrm{O}$, which rapidly dissolved leaving no residue. Silicon was added in the form of silicic acid powder $\left(\mathrm{SiO}_{2} \cdot 2 \mathrm{H}_{2} \mathrm{O}\right)$, which required heating of the silicacontaining solution to $87^{\circ} \mathrm{C}$ for at least three days to facilitate complete dissolution. These solutions were $\mathrm{pH}$-adjusted by use of $\mathrm{HNO}_{3}$ after addition of $\mathrm{Al}$ or Si to ensure that solutions were maintained at the appropriate $\mathrm{pH}$ value (typically $\mathrm{pH}=9$ ). The amount of $\mathrm{Al}$ or $\mathrm{Si}$ added to the solutions depended on the temperature of the experiment. Silicon was added to solution as a percentage of saturation with respect to amorphous silica. In other words, $\left(\mathrm{a}_{\mathrm{H} 4 \mathrm{SiO} 4} / \mathrm{a}^{*}{ }_{\mathrm{H} 4 \mathrm{SiO} 4}\right) \times 100$, where $\mathrm{a}_{\mathrm{H} 4 \mathrm{SiO} 4}$ is the activity of silicic acid in solution, $\mathrm{a}^{*}{ }_{\mathrm{H} 4 \mathrm{SiO} 4}$ is the concentration of silicic acid in equilibrium with amorphous silica, $\mathrm{SiO}_{2}(\mathrm{am})$. For example, because a ${ }^{*}{ }_{\mathrm{H} 4 \mathrm{SiO} 4}$ increases with temperature, a solution that is within $10 \%$ saturation at $40^{\circ} \mathrm{C}$ is far less saturated when the temperature is raised to $90^{\circ} \mathrm{C}$. Therefore, the range of Si concentrations added to solutions varied from approximately 10 to $150 \mathrm{ppm} \mathrm{Si}$. In the case of aluminum, it was difficult to add aluminum into solution without becoming supersaturated with respect to polymorphs of $\mathrm{Al}(\mathrm{OH})_{3}$ (e.g., gibbsite). As in the case of silicon, the amount of aluminum added depended upon the temperature of the experiment but can be summarized as from 10 to $100 \mu$ molal Al. To achieve a wide spread in aluminum and silicon activities in solution, a subset of solutions was prepared with both added $\mathrm{Al}$ and $\mathrm{Si}$. For these experiments, four different concentrations of $\mathrm{Al}$ were used. For each $\mathrm{Al}$ concentration, $\mathrm{Si}$ was added up to near saturation with respect to amorphous silica. Again, these additions probably caused the solutions to become supersaturated with respect to one or more aluminosilicate phase. Precipitation of solid phases can be visually detected in the effluent solution composition, as is fully discussed below. For experiments in which precipitation did not occur, the full extent to which $\mathrm{Al}$ and $\mathrm{Si}$ affect dissolution rates could be assessed. 


\subsubsection{SPFT Apparatus}

The salient features of the single pass flow-through (SPFT) apparatus used in this study are illustrated in Figure 2. Either a syringe (Kloehn; model 50300) or infusion pump (either 3M AVI Micro 210A or Graseby 3000) was used to transfer solution from the reservoir bottle to a Teflon reactor. In the case of the syringe pump, up to four experiments per pump could be run using the same input solution. This configuration was especially useful when experiments with varying flow-through rates were required. Infusion

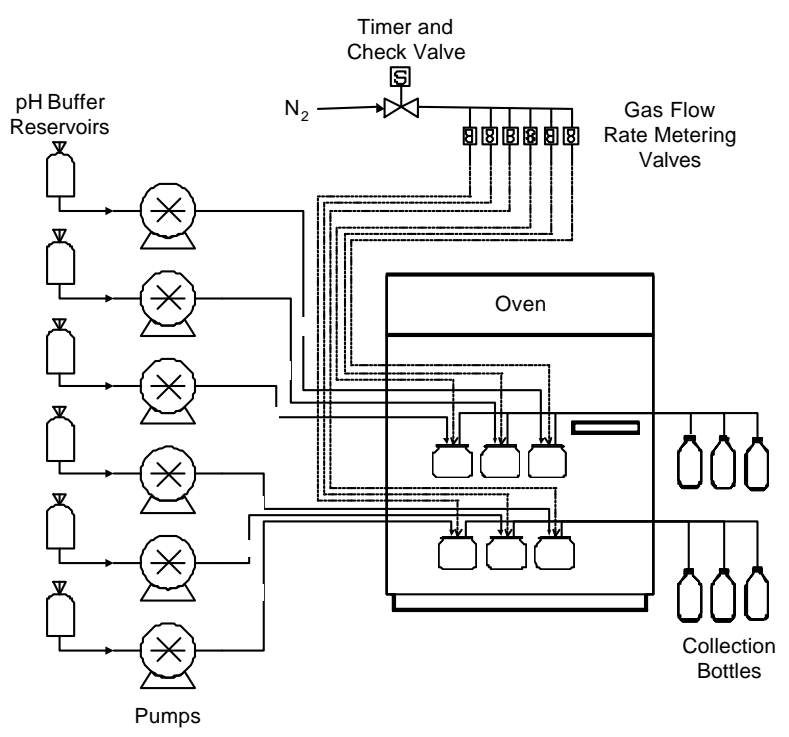

Figure 2. Schematic of the Single Pass FlowThrough (SPFT) Apparatus pumps were used when the input solutions contained $\mathrm{Al}$ or Si additives. Because no part of the infusion pump comes in contact with the solution, this precluded the possibility of contaminating later experiments. Transport of solution from the pumps was accommodated by $1 / 16^{\text {th }}$ inch Teflon tubing that led to a Teflon reservoir situated within a constant te mperature oven. The oven was set to the temperature of interest and a digital thermocouple, accurate to $\pm 2^{\circ} \mathrm{C}$, was used to record temperature daily. An in-line reservoir situated in the oven before the reactor was also used because the typical flow-through rates were fast enough that the solution may not have had time to equilibrate at the temperature of interest before entering the reactor. The reservoir vessel contains two ports, for inflow and outflow of solution, in addition to a third port for a nitrogen gas line. A nitrogen generator continuously supplied $\mathrm{N}_{2}$ to the reservoir, ensuring that atmospheric $\mathrm{CO}_{2}$ did not cause deviations in solution $\mathrm{pH}$. A Teflon line connected the reservoir to the reactor, which housed the powdered sample. The reactors consist of two pieces that screw together with the upper half containing a port for ingress of solution and a second port for the egress of effluent solution. The powdered sample lies at the bottom of the reactor in a thin layer. Therefore, the fluid is not pumped directly through the sample, as in other reactor designs. The advantage of this design is that bubbles that form in the fluid transfer lines do not become entrained in the sample, which could alter the exposed surface area. Effluent is collected continuously in collection bottles situated outside the oven. 
Aliquots of effluent solution were routinely checked to ensure that $\mathrm{pH}$ control was maintained during the experiment. The remainder of the effluent solution was acidified by high purity nitric acid and analyzed for chemical composition by ICP-OES methods. Typically, three blank solutions were drawn before glass was added to the reactor. The blank solutions were analyzed for background concentrations of elements of interest and, together with analyses of starting solution aliquots (see above), ensured that contamination from previous experiments was not a factor.

Experiments were terminated when the concentrations of elements in the effluent solution became invariant with respect to time (steady-state conditions). Typically, this would take from one to three weeks, depending upon the temperature of the experiments. For example, in order for boron concentrations to exceed its detection threshold, flow-through rates for experiments at $23^{\circ} \mathrm{C}$ were relatively slow $\left(=20 \mathrm{~mL} \mathrm{~d}^{-1}\right)$. In contrast, the concentration of boron in experiments at $90^{\circ} \mathrm{C}$ was well above detection threshold, even with flow-through rates as fast as $100 \mathrm{~mL} \mathrm{~d}^{-1}$. Since it typically takes exchange of seven reactor volumes to achieve steady-state conditions [13], the duration of an experiment at $23^{\circ} \mathrm{C}$ is longer than that at $90^{\circ} \mathrm{C}$.

\subsubsection{Dissolution Rate and Error Calculations}

Dissolution rates, based on steady-state concentrations of elements in the effluent, are normalized to the amount of the element present in the glass by the following formula:

$$
\text { Normalized dissolution rate }\left(\mathrm{g} \mathrm{m}^{-2} \mathrm{~d}^{-1}\right)=\frac{\left(C_{i}-\bar{C}_{i, b}\right) q}{f_{i} S}
$$

where $C_{i}$ is the concentration of the element, $i$, in the effluent $\left(\mathrm{g} \mathrm{L}^{-1}\right), \bar{C}_{i, b}$ is the average background concentration of the element of interest $\left(\mathrm{g} \mathrm{L}^{-1}\right), q$ is the flow-through rate $\left(\mathrm{L} \mathrm{d}^{-1}\right), f_{i}$ is the mass fraction of the element in glass (dimensionless), and $S$ is the surface area of the sample $\left(\mathrm{m}^{2}\right)$. The value of $f_{i}$ can be calculated from the chemical composition of the glass. Flowthrough rates were determined by gravimetric analysis of the fluid collected in each effluent collection vessel upon sampling. The background concentration of the element of interest is determined, as previously discussed, by analyses of the starting input solution and the three blank solutions. Typically, background concentrations of elements are below their respective detection threshold. The detection threshold of any element is defined here as the lowest calibration stan- 
dard that can be determined reproducibly during an analytical run within $10 \%$. Therefore, the detection threshold can be higher or lower for the same element on two separate analytical runs. For example, the detection threshold for boron may be as high as $100 \mathrm{ppb}$ (parts per billion) or as low as $5 \mathrm{ppb}$, depending how well the ICP-OES instrument operates on any particular day. In cases where the analyte is below the detection threshold, the background concentration of the element is set at the value of the detection threshold.

Dissolution rates were computed for elements whose concentrations are at least three times that of the detection threshold. In a few cases, concentrations are less than this and either the rate is not reported or is reported with all appropriate caveats. In the latter case, the uncertainty on the dissolution rate may be greater than the typical $35 \%$.

Determining the experimental uncertainty of the dissolution rate takes into account uncertainties of each parameter in Equation (4). For uncorrelated random errors, the standard deviation of a function $f\left(x_{1}, x_{2}, \ldots x_{n}\right)$ is given by:

$$
\sigma_{f}=\sqrt{\sum_{i=1}^{n}\left(\frac{\partial f}{\partial x_{i}}\right)^{2} \sigma_{i}^{2}}
$$

where

$$
\begin{aligned}
& \sigma_{f}=\text { standard deviation of the function } f \\
& x_{i}=\text { parameter } i \\
& \sigma_{I}=\text { standard deviation of parameter } i
\end{aligned}
$$

In the case of dissolution of a solid, the function of interest is Equation (4). Substituting (4) into (5) results in:

$$
\sigma_{R_{i}}=\sqrt{\left(\frac{q}{f_{i} S}\right)^{2}\left(\sigma_{C_{i}}^{2}+\sigma_{\bar{C}_{i, b}}^{2}\right)+\left(\frac{C_{i}-\bar{C}_{i, b}}{f_{i} S}\right)^{2} \sigma_{q}^{2}+\left(\frac{\left(C_{i}-\bar{C}_{i, b}\right) q}{f_{i}^{2} S}\right)^{2} \sigma_{f_{i}}^{2}+\left(\frac{\left(C_{i}-\bar{C}_{i, b}\right) q}{f_{i} S^{2}}\right)^{2} \sigma_{S}^{2}}
$$

Errors of $5 \%, 5 \%, 10 \%, 3 \%$, and $15 \%$ were assigned to $C_{i}, \bar{C}_{i, b}, q, f_{i}$, and $S$, respectively. Although the absolute error in $f_{i}$ is likely significantly higher than $3 \%$, this error is non-systematic and so does not contribute significantly to sample-to-sample uncertainty, which is the principal error of interest here. The conservative appraisal of errors assigned to the parameters in Equa- 
tion (6), in addition to the practice of imputing detection threshold values to background concentrations, results in uncertainties of approximately $\pm 35 \%$ on the dissolution rate.

\subsection{RESULTS FOR LAWABP1 GLASS}

Dissolution rates and experimental conditions, including temperature, solution $\mathrm{pH}$, flowthrough rates, and sample mass and surface area, are listed in the Appendix. The majority of the rates reported are computed based on concentration of boron. Boron is typically the most reliable index for matrix dissolution since it, along with $\mathrm{Si}$ and $\mathrm{Al}$, forms the glass polymer network. In addition, when boron is released during dissolution, it is not retained either in secondary mi nerals or in "leach layers" that build up on the surface of glass. Other network forming elements, such as $\mathrm{Al}$ and $\mathrm{Si}$, may be retained after initial release in experiments with slow flow-through rates and, clearly, neither $\mathrm{Al}$ nor Si can be used as an index of dissolution in cases where these elements are added to input solutions. Rates based on alkali elements, in this case, $\mathrm{Na}$, are also subject to uncertainty under conditions of slow matrix dissolution rates. As discussed in more detail below, release of $\mathrm{Na}$ to solution is through two separate reactions, matrix dissolution, and alkali-hydrogen exchange. For example, when flow-through rates are slow, the concentration of $\mathrm{Si}$ in solution in contact with glass builds up, causing the dissolution rate to decrease. Relatively large amounts of $\mathrm{Na}$ are released into solution, however, because the $\mathrm{Na}^{+}-\mathrm{H}^{+}$exchange mechanism continues to operate. Thus, in this example, the calculated dissolution rate would be too fast. In many experiments, however, the $\log _{10}$ dissolution rate based upon $\mathrm{Al}, \mathrm{B}, \mathrm{Na}$, and $\mathrm{Si}$ agrees to within $0.2 \log$ units and is reported as an average. In some extreme cases, the concentration of boron in solution is below the detection threshold and we are forced to rely on concentrations of $\mathrm{Al}, \mathrm{Na}$, and $\mathrm{Si}$ for computing dissolution rates. This may occur, for example, when flow-through rates are very fast and concentrations of elements in the effluent are dilute. However, if these rates are in disagreement with each other, for the reasons mentioned above, then dissolution rates for that experiment are not reported. 


\subsubsection{Achievement of Steady-State and Consistency of Results}

As stated earlier in this report, obtaining valid dissolution rates depends on the glasssolution system reaching steady-state conditions. Figure 2 shows that these conditions are met for typical experiments at the four temperatures $\left(23,40,70\right.$, and $\left.90^{\circ} \mathrm{C}\right)$ investigated. Concentrations of boron are invariant with respect to time after $\sim 10$ days in these experiments. The results shown in this diagram are typical of what we observed for all experiments.

For experiments performed under similar

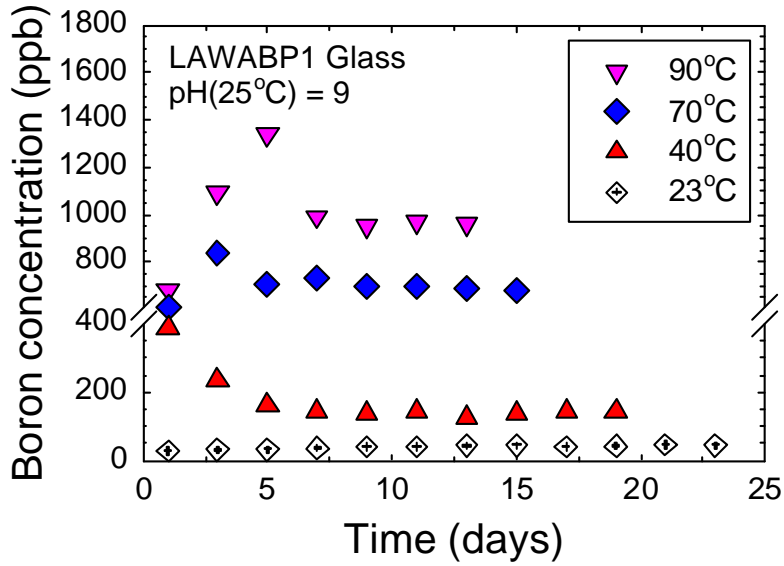

Figure 3. Boron Concentration Versus Time for the Four Temperatures Investigated. This plot illustrates that the system achieves steadystate conditions in $\sim 10$ days. Note scale break in vertical axis.

conditions, the data generally yield consistent rate measurements. For example, experiments at $\mathrm{pH}\left(23^{\circ} \mathrm{C}\right)=9$ and flow-through rates between 80 and $100 \mathrm{~mL} \mathrm{~d}^{-1}$ gave $\log _{10}$ dissolution rates between -0.71 to $-0.84 \mathrm{~g} \mathrm{~m}^{-2} \mathrm{~d}^{-1}$ (see Appendix). The $\log _{10}$ mean rate, based on 9 experiments, is $0.784 \pm 0.108 \mathrm{~g} \mathrm{~m}^{-2} \mathrm{~d}^{-1}$ (two standard deviations). However, one experiment (\#80) is inexplicably faster than all of the others $\left(-0.59 \mathrm{~g} \mathrm{~m}^{-2} \mathrm{~d}^{-1}\right)$. Including this value, the $\log _{10}$ mean rate is -0.765 $\pm 0.160 \mathrm{~g} \mathrm{~m}^{-2} \mathrm{~d}^{-1}$. We therefore conclude that the SPFT experiments are generally internally consistent with nearly all rate values within \pm 0.2 $\log$ units of each other.

\subsubsection{Effect of $q / s$ Variations}

Figure 4 illustrates the effect of varying the ratio of flow-through rate, $q$, to sample surface area, $S$. Rates based on concentrations of $\mathrm{Al}, \mathrm{B}, \mathrm{Si}$, and $\mathrm{Na}$ are plotted for the conditions of $90^{\circ} \mathrm{C}, \mathrm{pH}\left(25^{\circ} \mathrm{C}\right)=9$. This figure illustrates that as the $q / S$ ratio increases, dissolution rates increase and then reach a constant value. This figure also shows that the rates

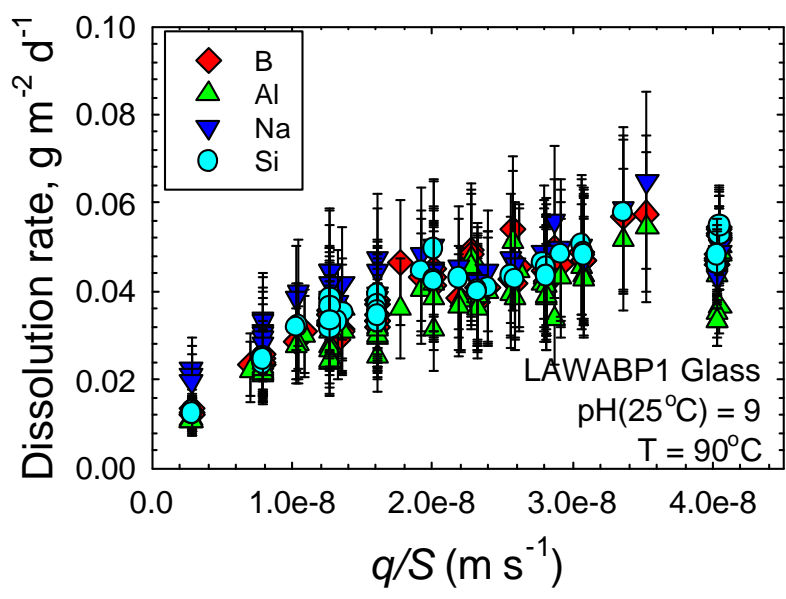

Figure 4. Effect of Variation in the Ratio of Flow Rate, $q$, to Sample Surface Area, $S$, on Glass Dissolution Rate. Note that the normalized rates for $\mathrm{Al}, \mathrm{B}, \mathrm{Na}$, and $\mathrm{Si}$ reach an equivalent constant value at higher values of $q / s$. 
based on all four elements (Al, B, Na, and $\mathrm{Si}$ ) are nearly identical over the $q / S$ values studied, indicating that the glass is dissolving congruently, especially at higher $q / S$ ratio.

Figure 4 illustrates that the effect of $q / S$ on rates is similar at 40,70 , and $90^{\circ} \mathrm{C}$. For all three temperatures, the rate increases to a maximum and thereafter remains constant. This maximum rate is commonly known as the forward rate. The reason that rates are relatively slow on the left-hand side of the diagram (toward smaller values of $q / S$ ) is that when flow-rates are low or when total surface area is high, the concentrations of elements dissolved into solution are high. As the concentration of elements rise in solution, the so-

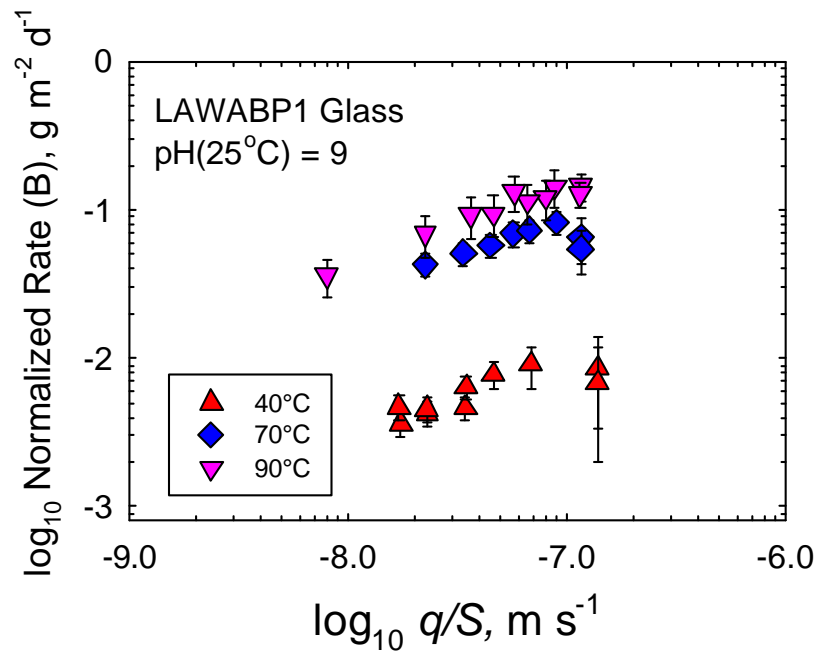

Figure 5. Effect of Variation in the Ratio of Flow Rate, $q$, to Sample Surface Area, $S$, on Glass Dissolution Rate at Various Temperatures lution approaches saturation with respect to some solid phase or phases. Therefore, the dissolution rate slows as the chemical potential difference between glass and solution decreases. This effect is expressed mathematically as the chemical affinity of reaction:

$$
\text { Chemical affinity }=\mathrm{R} \ln \left(\frac{K_{g}}{Q}\right)=-\Delta G_{r}
$$

where $-\Delta G_{r}$ is the free energy of reaction, and $\mathrm{R}, T, K_{g}$, and $Q$ are as defined in Equation (2). In other words, the chemical affinity is a measure of the departure from equilibrium. Therefore, as the ion activity product, $Q$, approaches the value of $K_{g}$, the natural $\log$ of the ratio $K_{g} / Q \rightarrow 0$ and the chemical affinity term goes to zero. 


\subsubsection{Calculation of $\eta, \underline{k}, \underline{\text { and } \mathrm{E}_{\underline{a}}}$}

Solution $\mathrm{pH}$ values were varied between 2 and 11 at temperatures of $23,40,70$ and $90^{\circ} \mathrm{C}$ (see Table 3). Because the pore water solution in the disposal system is expected to be neutral to basic, only the results of the experiments for this $\mathrm{pH}$ range will be discussed. Figure 6 illustrates the effect of $\mathrm{pH}$ on the forward rate for LAWABP1 glass. Note that the in-situ $\mathrm{pH}$ has been corrected for temperature using the EQ3/6 computer code. For the four temperatures studied, the data indicate similar behavior with rates increasing with $\mathrm{pH}$. The slope of a line through the data

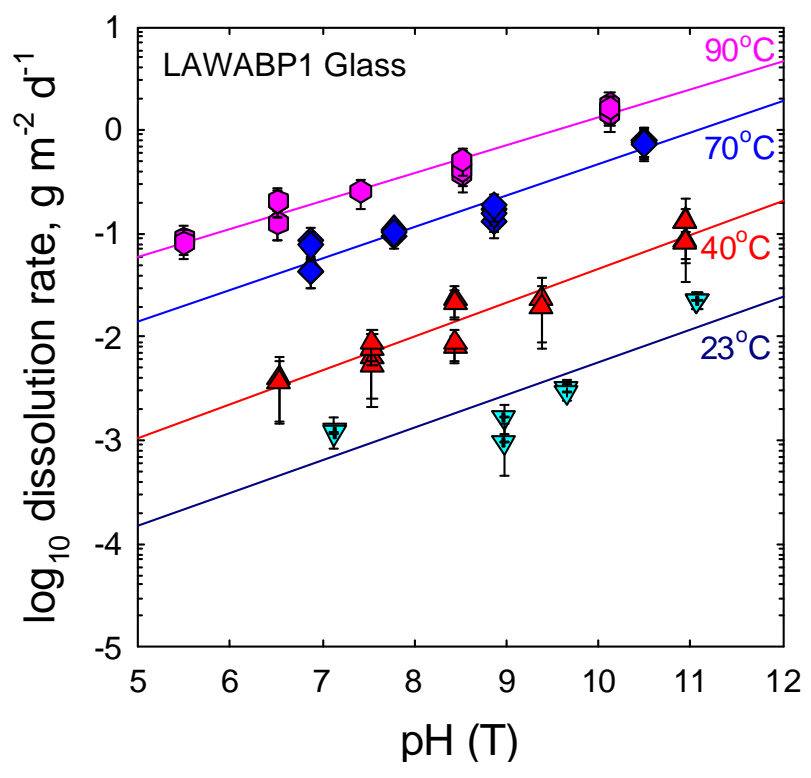

Figure 6. $\log _{10}$ Dissolution Rate Versus Temperature Corrected $\mathrm{pH}$ for LAWABP1 Glass points corresponding to each temperature is equal to $\eta$, which is one of the parameters in Equation (2). The value of the slope is $0.35 \pm 0.03$ for all four temperatures plotted. The value of $\eta$ is similar to what we determined previously for LD6-5412 glass [8]. In addition, the value of $\eta$ for LAWABP1 glass is consistent with values reported for silicate minerals [14]. Because $\eta$ is not dependent upon temperature, we can set $\eta=0.35$ at the anticipated repository temperature of $15^{\circ} \mathrm{C}$ with confidence.

Figure 4 also illustrates the strong effect that temperature has on dissolution rates. Dissolution rates increase by $\sim 1,000 \mathrm{X}$ over the temperature interval of 23 to $90^{\circ} \mathrm{C}$. Because the solutions were kept dilute during the SPFT experiments, the chemical affinity term $\left(1-Q / K_{g}\right)$ in Equation (2) can be neglected and a nonlinear regression performed to estimate the remaining two unknown terms $\left(\vec{k}\right.$, and $\left.\mathrm{E}_{\mathrm{a}}\right)$. The regression yields an activation energy of $68 \pm 3 \mathrm{~kJ} \mathrm{~mol}^{-1}$, which is similar to the $75 \mathrm{~kJ} / \mathrm{mol}$ determined for LD6-5412 glass [8] and $\vec{k}=3.4 \pm 0.3 \times 10^{6} \mathrm{~g} \mathrm{~m}^{-2} \mathrm{~d}^{-1}$. Note that the value of $E_{a}$ for these glasses is similar to that of silica polymorphs (quartz $=66-83$ $\mathrm{kJ} \mathrm{mol}^{-1}$ [15]; amorphous silica, $74.5 \mathrm{~kJ} \mathrm{~mol}^{-1}$ [16]; cristobalite, $68.9 \mathrm{~kJ} \mathrm{~mol}^{-1}$ [17]). Rupture of the $\mathrm{Si}-\mathrm{O}$ bond in borosilicate glass appears to be the rate-limiting step in dissolution. 


\subsubsection{Determination of $K_{g}$}

In using Equation (2) for modeling glass dissolution kinetics, it must be recognized that there is still debate in the scientific community regarding the inclusion of other aqueous species, such as $\mathrm{AlO}_{2}^{-}$or $\mathrm{Na}^{+}$, as inhibitor or catalyzing species in the $\prod_{j} a_{j}^{\eta_{j}}$ term or to include them as part of the pseudoequilibrium constant $K_{g}$ [18]. Abraitis et al. [10] were unable to model their SPFT data with a HLW glass using aluminate as an inhibitor species. Also, McGrail et al. [19] point out that use of inhibitor species in Equation (2) can be problematic in PA simulations because the concentration of species such as $\mathrm{AlO}_{2}{ }^{-}$can drop to very low values, causing the predicted glass dissolution rates to be high, even in a silica saturated solution. Because of this concern, we will not consider further the inclusion of an inhibitor term in Equation (2).

Assigning $K_{g}$ to a hypothetical phase including all the glass elements has not proven successful in modeling laboratory test data [20,21]. Grambow [22] proposed that the value of $K_{g}$ should be equivalent to one of the silica polymorphs e.g., amorphous silica or chalcedony. Bourcier [23] proposed that $K_{g}$ should only include a subset of glass component species found in secondary corrosion products but Jégou, Gin, and Larché [24] showed that Bourcier's model fails to describe the behavior of even a simple sodium borosilicate glass. We will examine the consistency of our SPFT data with these hypotheses and show how a secondary reaction mechanism, alkali ion exchange, may explain some of the reported deviations from the chemical affinity rate law as a function of solution composition.

\subsubsection{Solutions Doped with $\mathrm{Si}$}

Silicon, as $\mathrm{SiO}_{2}$ (aq), was added to input solutions over the concentration interval of 20 to 120 ppm. As discussed in Section 3.1.2, silicon was added by dissolving powdered $\mathrm{SiO}_{2} \cdot 2 \mathrm{H}_{2} \mathrm{O}$ into a $0.05 \mathrm{M}$ THAM solution, $\mathrm{pH}$-adjusted to $9\left(\right.$ at $\left.23^{\circ} \mathrm{C}\right)$. The amount added to each solution is listed in the Appendix as mol/L Si in the effluent solution. The range in concentration of $\mathrm{Si}$ in the effluent is from $<5 \%$ to $>100 \%$ of the saturation value with respect to amorphous silica at $26^{\circ} \mathrm{C}$ and up to $95 \%$ at $40^{\circ}$ and $70^{\circ} \mathrm{C}$. The concentration of $\mathrm{Si}$ in the effluent solutions in the $90^{\circ} \mathrm{C}$ experiments was only up to $\sim 70 \%$ with respect to saturation. 


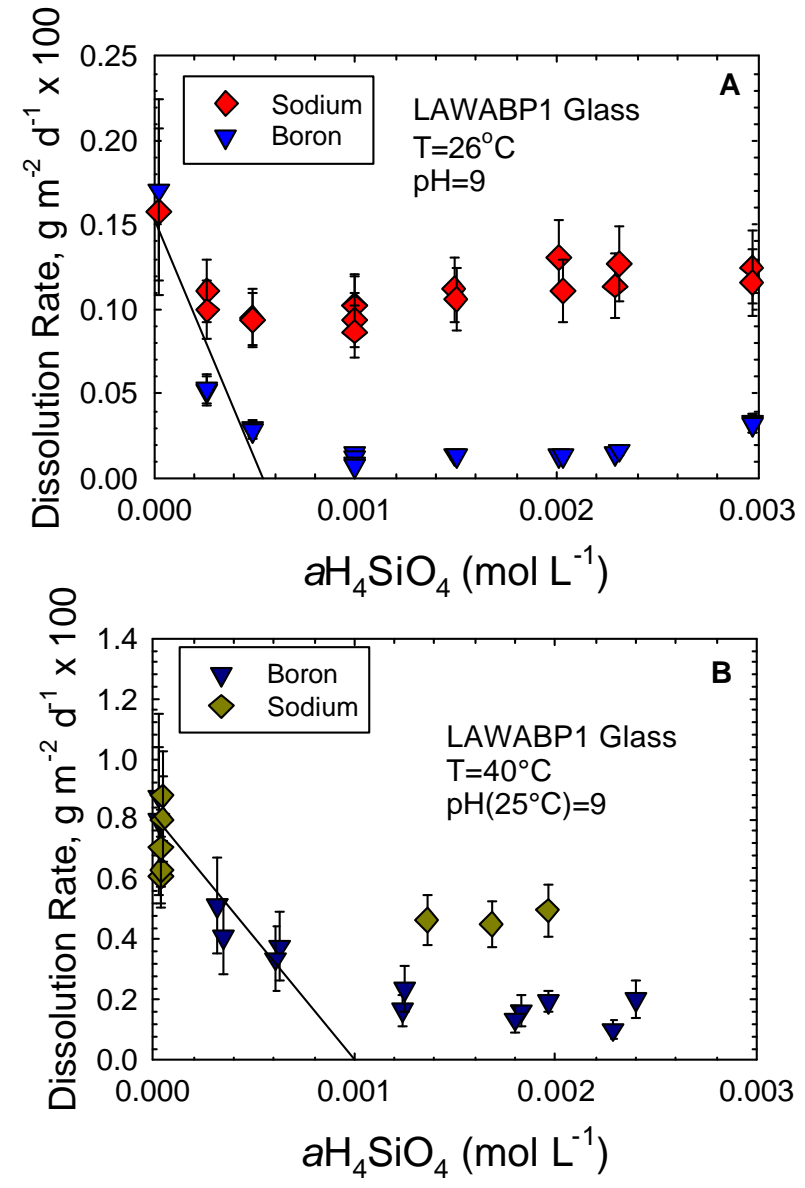

Figure 7. Plot of Dissolution Rates Based on $\mathrm{B}$ and $\mathrm{Na}$ Versus the Activity of Silicic Acid at 26 and $40^{\circ} \mathrm{C}$
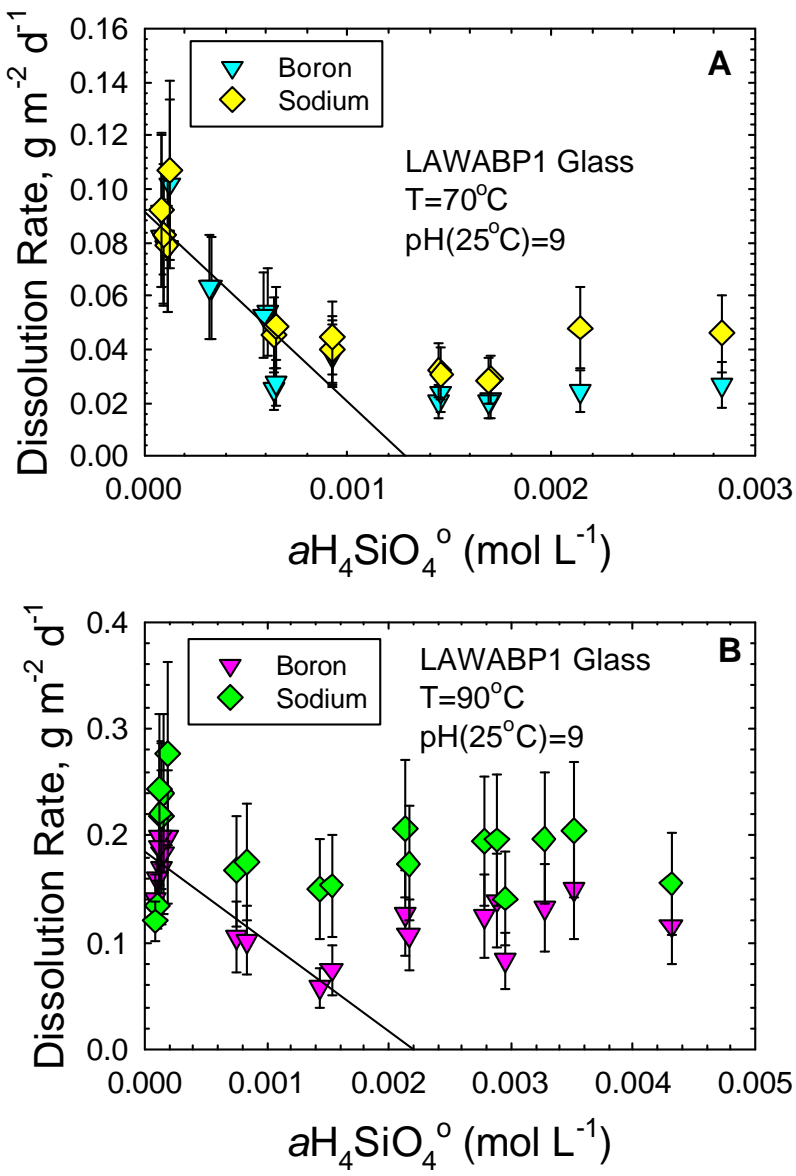

Figure 8. Plot of Dissolution Rate with Respect to B and Na Versus Silicic Acid Activity at 70 and $90^{\circ} \mathrm{C}$.

Figure 7 and Figure 8 illustrate the effect of silicon on the dissolution rate of LAWABP1 glass. Dissolution rates with respect to both boron and sodium are plotted against the activity of silicic acid at $26,40,70$, and $90^{\circ} \mathrm{C}$. At the temperature and $\mathrm{pH}$ of these experiments, silicic acid $\left(\mathrm{H}_{4} \mathrm{SiO}_{4}{ }^{\circ}\right)$ is the dominant aqueous species, although smaller fractions of $\mathrm{H}_{3} \mathrm{SiO}_{4}{ }^{-}(\sim 11 \%)$ and $\mathrm{H}_{2} \mathrm{SiO}_{4}{ }^{2-}(\ll 1 \%)$ are also present. Dissolution rates, based on boron release, decrease rapidly and then reach a constant value with increasing activity of silicic acid. Rates based on sodium also become constant at higher activities of $\mathrm{H}_{4} \mathrm{SiO}_{4}$, but are consistently faster than the boron release rates.

Figures 6 and 7 collectively indicate that dissolution rates decrease non-linearly with respect to silicic acid activity. This behavior would apparently contradict the proposal of Grambow [22] in which the activity of silicic acid alone is assumed to control the dissolution rate of borosilicate 
glass. However, McGrail et al. [25] argue that the non-linear behavior can be attributed to a secondary reaction mechanism, alkali ion exchange. Under dilute solution conditions (low silicic acid activities), sodium and boron rates are identical within experimental error, as can be seen in Figures 6 and 7. As the concentration of dissolved silicon increases, however, the sodium rates become statistically faster than boron rates. The divergence in sodium and boron release rates at high silicon concentrations can be explained by the operation of two distinct mechanisms that release Na to solution. Under conditions of dilute solution compositions, matrix dissolution dominates so normalized boron and sodium release rates are equal. As silicon is added to solution, matrix dissolution rates decrease. However, the $\mathrm{Na}^{+}-\mathrm{H}^{+}$exchange reaction

$$
\equiv \mathrm{Si}-\mathrm{O}^{-} \mathrm{Na}^{+}+\mathrm{H}^{+} \rightarrow \equiv \mathrm{Si}-\mathrm{O}^{-} \mathrm{H}^{+}+\mathrm{Na}^{+}
$$

is unaffected by the concentration of silicic acid and so continues to release $\mathrm{Na}$ at a constant rate. Reaction (7) also produces a silanol group and increases the local $\mathrm{pH}$, thus catalyzing the irreversible hydrolysis reaction

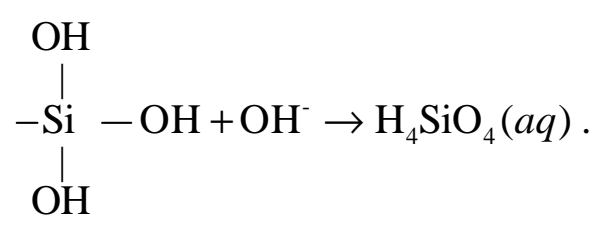

Consequently, reaction (7) affects the overall rate at which reaction (8) proceeds because it impacts the rate at which $\mathrm{Si}-\mathrm{OH}$ groups are produced. However, three silanol groups must be formed before the last anchoring bond is broken [7], releasing a silicic acid $\left(\mathrm{H}_{4} \mathrm{SiO}_{4}\right)$ molecule into solution. The degree of glass polymerization obviously significantly impacts the overall hydrolysis rate. Reactions (7) and (8), therefore, are linked but can proceed at different rates, consistent with the data shown in Figures 6 and 7. If this argument is correct, then the observed deviations from the linear behavior expected from the kinetic rate law (2) are caused by alkali-H exchange and not by a fundamental discrepancy per se with the rate law itself.

In Figures 6 and 7, a line is projected through the linear portion of the diagram to derive a theoretical estimate for $K_{g}$. These $K_{g}$ values are plotted as a function of temperature in Figure 9, along with the $\log _{\mathrm{e}} \mathrm{K}$ values for $\mathrm{SiO}_{2}(\mathrm{am})$ and quartz. As can be seen from Figure 9, the calculated $K_{g}$ for LAWABP1 glass falls in between the equilibrium constants for $\mathrm{SiO}_{2}(\mathrm{am})$ and quartz. A simple linear regression through the data yields an apparent reaction enthalpy $(\Delta \mathrm{H})$ for 
LAWABP1 glass of $16.9 \pm 3 \mathrm{~kJ} / \mathrm{mol}$, which is identical (within experime ntal error) to $\mathrm{SiO}_{2}(\mathrm{am})$ with $\Delta \mathrm{H}=15 \mathrm{~kJ} / \mathrm{mol}$ but significantly different from quartz with $\Delta \mathrm{H}=26.4$ $\mathrm{kJ} / \mathrm{mol}$. Using the regression, the $\log _{10} K_{g}$ at $15^{\circ} \mathrm{C}$ is -3.3 .

\subsubsection{Solutions Doped with Al}

Aluminum was added to select experiments by dissolving aluminum trinitrate hydrate $\left[\mathrm{Al}\left(\mathrm{NO}_{3}\right)_{3} \cdot 9 \mathrm{H}_{2} \mathrm{O}\right]$ crystals into $0.05 \mathrm{M}$ THAM solutions. Solution $\mathrm{pH}$ values were then adjusted to 9 by addition of $\mathrm{HNO}_{3}$. The

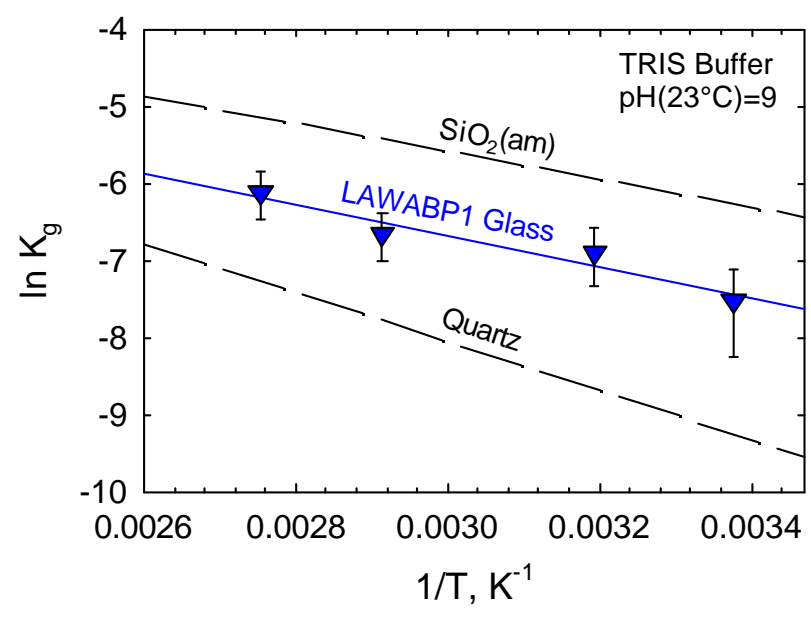

Figure 9. $\log _{\mathrm{e}} K_{g}$ Versus $1 / \mathrm{T}$ for LAWABP1 Glass. Dashed lines are the calculated $\log _{\mathrm{e}} K$ for quartz and amorphous silica. A linear regression for the LAWABP1 data yields a reaction enthalpy $(\Delta \mathrm{H})$ of $16.9 \pm 3 \mathrm{~kJ} / \mathrm{mol}$.

amount of dissolved aluminum added to the input solutions varied over a concentration range of 20 to $120 \mu \mathrm{mol}$ Al. The maximum amount of aluminum added was dependent on, as in the case of silicon, the temperature of the experiment, but in most cases, the amount of Al probably resulted in precipitation of aluminum hydroxide or aluminosilicate phases. In a subset of experiments, both $\mathrm{Al}$ and $\mathrm{Si}$ were added to the input solution. To be able to compare experiments over the temperature interval studied $\left(40\right.$ to $\left.90^{\circ} \mathrm{C}\right)$, we kept the range of $\mathrm{Al} / \mathrm{Si}$ ratios the same. As in the case of the Al only experiments, precipitation of solid phases likely occurred over the duration of the experiments. The effects of the precipitated phases will be discussed below.

The following figures illustrate the extent to which dissolution rates are suppressed when aluminum is added to solution. Figure 10 shows that dissolution rates decrease linearly as activity of the aluminate ion, $\mathrm{Al}(\mathrm{OH})_{4}{ }^{-}$, increases. The aluminate ion is the dominant aluminum species at the test $\mathrm{pH}$. These results again argue against Grambow's model [22], wherein the activity of silicic acid alone governs the dissolution rate of glass. Another noteworthy feature of this diagram is that the rates are suppressed by a factor of $\sim 4 \mathrm{X}$, which is approximately the same magnitude to which addition of silicon suppresses rates at the same te mperature (see Figure 7). 
Accounting for the effect of aluminum in the kinetic rate law (2) is a topic of considerable debate in the geochemical literature. Gin [18] has advocated a mixed Al-Si activity product in which the activities of $\mathrm{AlO}_{2}{ }^{-}$and $\mathrm{SiO}_{2}(\mathrm{aq})$ are raised to an exponent equal to their respective mole fractions in the glass. In the case of LAWABP1 glass, the exponent values are 0.136 and 0.482 for aluminum and silicon, respectively. However, there is no reason to believe that the bulk glass composition serves as a governor of aluminate and silicic acid activities. Alternatively, precipitation of a secondary corrosion product, either crystalline or amorphous, may control the concentration of these species.

Figure 11 illustrates a plot of $\log _{10}$ activity $\mathrm{SiO}_{2}(\mathrm{aq})$ versus $\log _{10} \mathrm{AlO}_{2}^{-}$for experiments doped with $\mathrm{Al}$ or Si. For the three temperatures considered, lines regressed through the data points are near a one-to-one ratio. These data are consistent with solution composition control by a phase such as kaolinite, $\mathrm{Al}_{2} \mathrm{Si}_{2} \mathrm{O}_{5}(\mathrm{OH})_{4}$. Kaolinite has been observed at $99^{\circ} \mathrm{C}$ in PUF column tests. Another possibility is that the solid phase that is precipitating is a smectite, which has the general formula of $(\mathrm{A})_{0.7}(\mathrm{~B})_{4}\left[(\mathrm{Si}, \mathrm{Al})_{8} \mathrm{O}_{20}\right](\mathrm{OH})_{4} \cdot n \mathrm{H}_{2} \mathrm{O}$, where " $\mathrm{A}$ " is an interlayer (alkali or alkaline earth) cation, and " $\mathrm{B}$ " is an octahedral (6-fold coordinated) cation. Certain smectite phases (e.g., beidellite) have Al:Si ratios that approach 1:1.

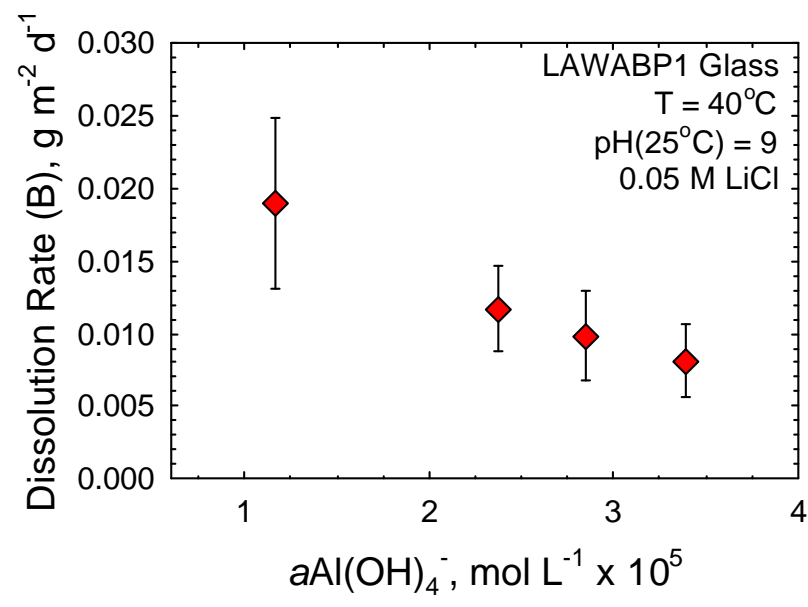

Figure 10. Plot of Dissolution Rate Versus Activity of Aluminate Ion for LAWABP1 Glass, $40^{\circ} \mathrm{C}$. The figure illustrates that dissolution rates decrease with the progressive increase in added Al. Note that the solution also contained a high concentration of $\mathrm{LiCl}$, so the rates are not comparable to rates in DIW.

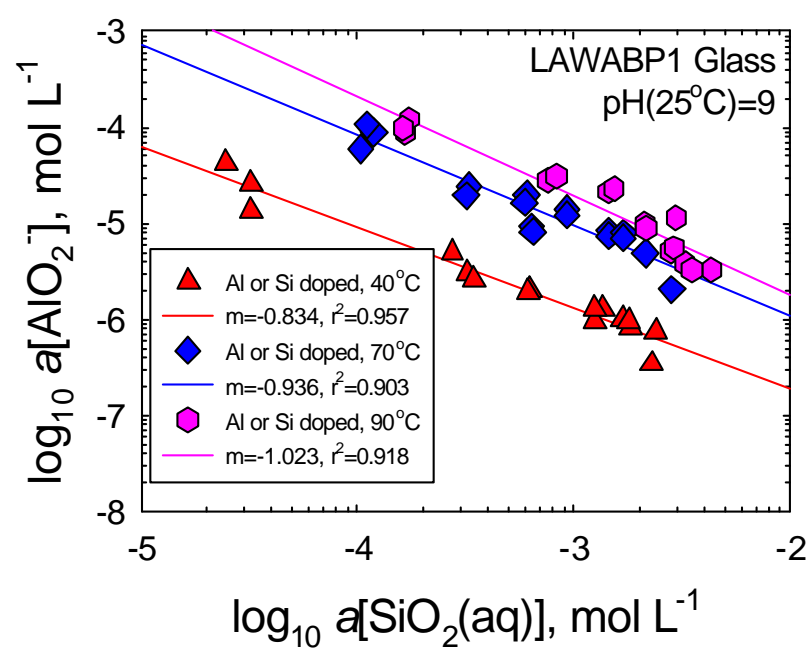

Figure 11. Plot of the $\log _{10}$ of Silicic Acid and Aluminate Ion Activities at 40,70 , and $90^{\circ} \mathrm{C}$. The slopes of the lines through the three data sets are consistent with control of $\mathrm{Al}$ and $\mathrm{Si}$ activities by a phase with a $\mathrm{Si}: \mathrm{Al}$ ratio of $1: 1$. 

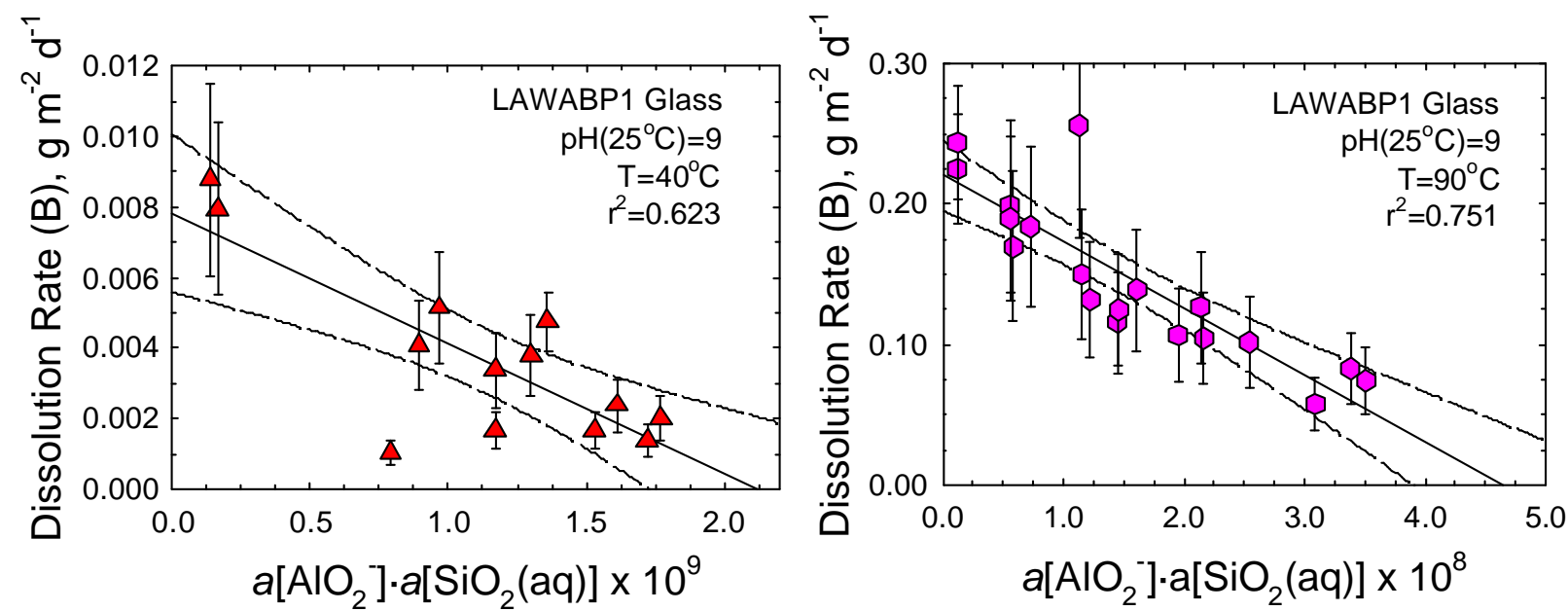

Figure 12. Plot of Dissolution Rate at 40 and $90^{\circ} \mathrm{C}$ Versus 1:1 Mixed Al-Si Activity Product. The solid line is the regression whereas the dashed lines represent the $95 \%$ confidence limit.

Figure 12 shows the dissolution rate of LAWABP1 glass as a function of a mixed $\mathrm{Al}: \mathrm{Si}$ activity product with $\mathrm{Al}: \mathrm{Si}$ ratio of $1: 1$. The data show a reasonably linear correlation. From the $\mathrm{x}$-intercepts of the regression, it is possible to calculate an ion activity product assuming kaolinite is the rate-determining solid. The pertinent reaction is

$$
1 / 2 \mathrm{Al}_{2} \mathrm{Si}_{2} \mathrm{O}_{5}(\mathrm{OH})_{4}=\mathrm{AlO}_{2}^{-}+\mathrm{SiO}_{2}(\mathrm{aq})+\mathrm{H}^{+}+1 / 2 \mathrm{H}_{2} \mathrm{O}
$$

Table 4 shows the regressed ion activity product for Reaction (9) as a function of temperature versus the $\log _{10} K$ for kaolinite obtained from the EQ3NR database. The regressed values of $Q$ are about 1.5 orders of magnitude larger than the solubility product for kaolinite. This could reflect the formation of an amorphous solid with similar stoichiometry but greater solubility than kaolinite, which would be expected at the low temperature and short duration of these SPFT tests.
Table 4. Comparison of Ion-Activity Product Regressed From SPFT Tests with Solubility Product for Kaolinite

$\begin{array}{ccc}\underline{\mathrm{T}\left({ }^{\circ} \mathrm{C}\right)} & \underline{\log _{10} Q} & \underline{\log K} \\ 23 & -17.7 \pm 0.2 & -19.4 \\ 40 & -17.1 \pm 0.3 & -18.6 \\ 70 & -15.5 \pm 0.3 & -17.2 \\ 90 & -14.8 \pm 0.3 & -16.5\end{array}$



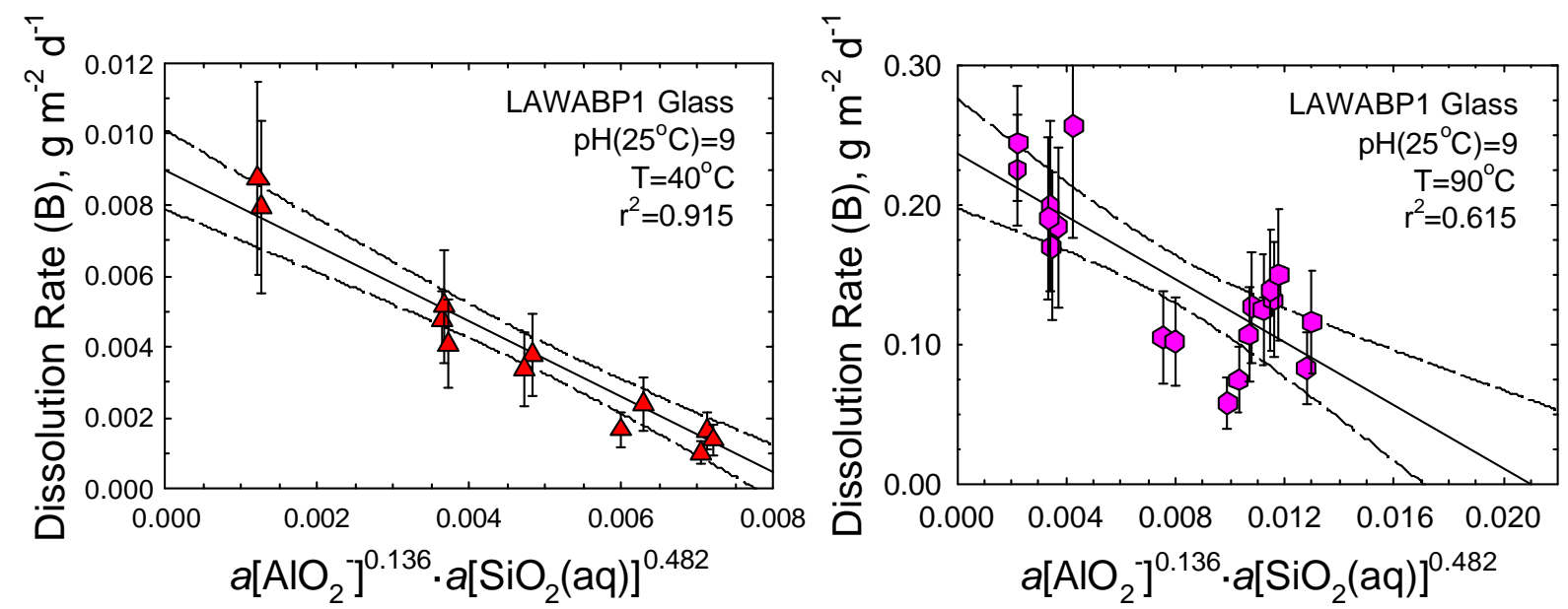

Figure 13. Plot of Dissolution Rate at 40 and $90^{\circ} \mathrm{C}$ Versus a Mixed Al-Si Activity Product Based on Bulk Glass Stoichiometry. The solid line is the regression and the dashed lines represent the $95 \%$ confidence limit.

An alternative to using a mixed Al-Si activity product with $\mathrm{Al}$ :Si ratio of $1: 1$ is to use the activity product proposed by Gin [18]. Figure 13 shows that this activity product term also generates a good linear correlation with boron-based dissolution rates. However, as Figure 13 shows, when the data set is extended to include the experiments where both Si and Al were added to the input solution (higher values of the activity product) the results look similar to what was observed with the silicic acid only model (Figure 7). The non-linearity of the data in Figure 14 could indicate 1) that neither the Gin model nor the activity product with a 1:1 Si:Al ratio adequately describes the data set, 2) the calculated activity products are in error because very finegrained minerals (e.g., kaolinite, gibbsite) could have been in colloidal suspension not in true solution, or 3) deviations are due to the effect of alkali ion exchange as described previously. Although probably unlikely, we cannot exclude possibility \#2 at this time because the effluent solution samples were acidified prior to analysis and any undetected precipitate would dissolve into solution. If this occurred, analyses of the effluent solution would reflect spuriously high concentrations of $\mathrm{Al}$ and $\mathrm{Si}$ in solution. 
One test of the alkali ion exchange hypothesis is to examine a data set for a glass composition that is not susceptible to the exchange reaction. According to the model developed by McGrail et al. [25], sodium atoms in non-bridging oxygen (NBO) sites are the only ones susceptible to $\mathrm{Na}^{+}-\mathrm{H}^{+}$exchange. Consequently, a glass with few NBO sites should have very little alkali ion exchange and so should more closely follow the kinetic rate law (2). To test this hypothesis, we performed a set of experiments on a boroaluminosilicate glass that has a molar ratio of $\mathrm{Na} /(\mathrm{Al}+\mathrm{B})$ equal to unity. This ratio is important because if the value of $\mathrm{Na} /(\mathrm{Al}+\mathrm{B})$ exceeds one (assuming all the $\mathrm{Al}$ and $\mathrm{B}$ is in tetrahedral coordination), the excess sodium atoms create NBO sites in glass. Sodium atoms bonded to $\mathrm{AlO}_{4}{ }^{-}$ and $\mathrm{BO}_{4}{ }^{-}$units as charge compensators are much more difficult to remove by ion exchange reactions.
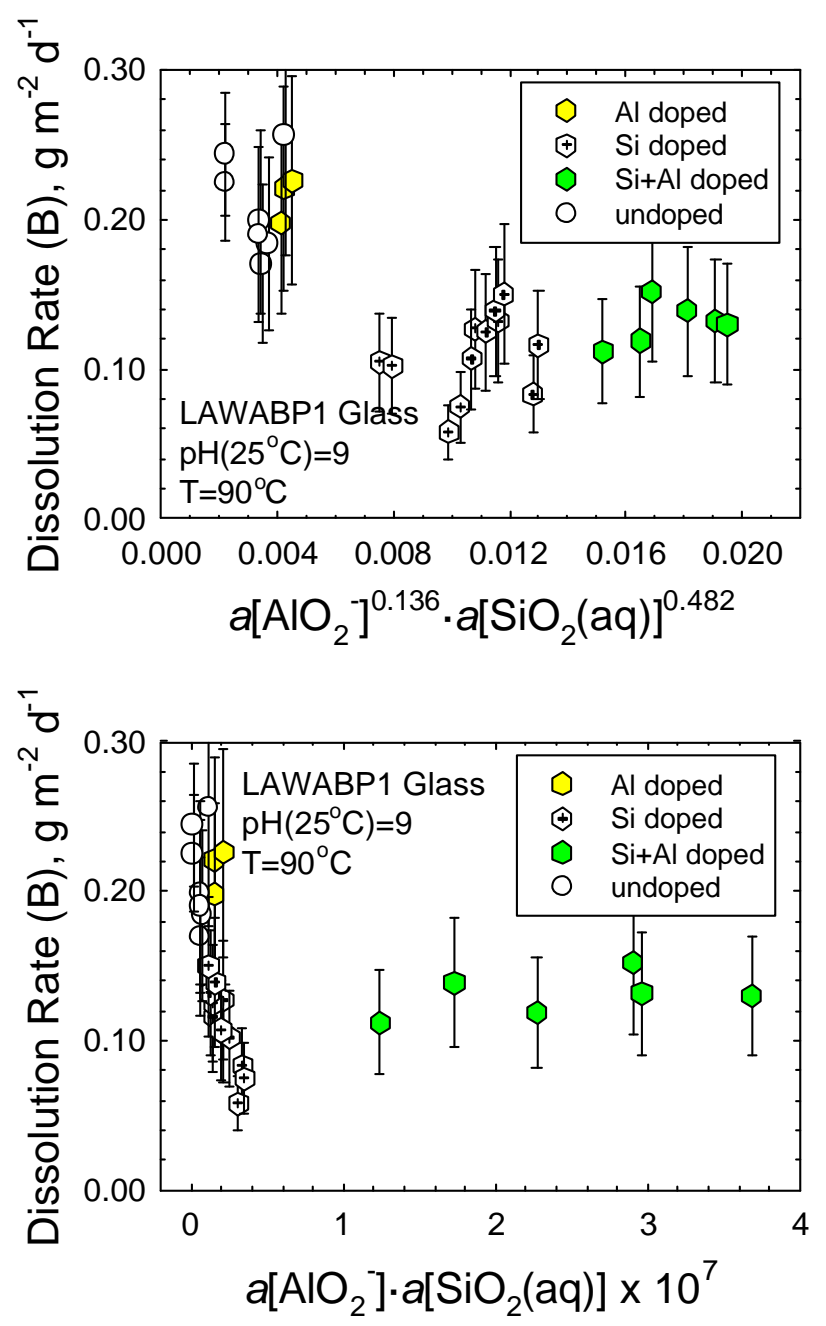

Figure 14. Plots of Dissolution rate at $90^{\circ} \mathrm{C}$ Versus the Two Competing Al-Si Activity Product Schemes. Including data for $\mathrm{Al}+\mathrm{Si}$ doped solutions results in a distinct non-linearity in the data. 
Figure 15 shows the normalized release rate for $\mathrm{Na}$ and $\mathrm{B}$ as a function of silicic acid concentration. First, it is apparent from the data that the glass is dissolving congruently, even at high $\mathrm{SiO}_{2}$ (aq) concentrations; the glass is not susceptible to $\mathrm{Na}$ ion exchange. Second, the dissolution rate decreases linearly as silica is added to solution over most of this diagram. The relatively slow rate at low activities of silicic acid can be explained by the higher concentrations of $\mathrm{Al}$ in solution at low $\mathrm{Si}$ concentrations. As more $\mathrm{Si}$ is added into solution, $\mathrm{Al}$ and $\mathrm{Si}$ form a hydrous gel at the glass surface and the activity of $\mathrm{AlO}_{2}^{-}$decreases, allowing the dissolution rate to in-

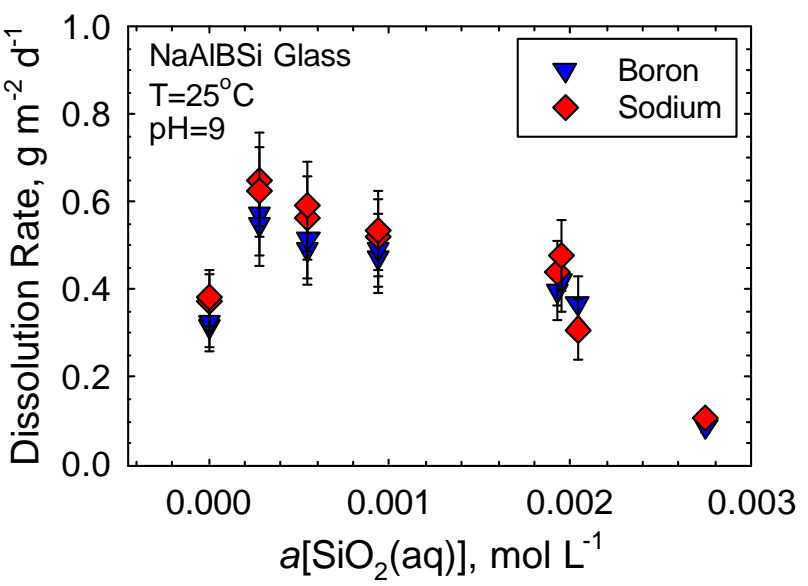

Figure 15. Plot of Dissolution Rate Versus Activity of Silicic Acid for a Boroaluminosilicate Glass at $25^{\circ} \mathrm{C}$. In contrast to ILAW glass compositions, this glass contains few NBO's because molar $\mathrm{Na} /(\mathrm{Al}+\mathrm{B})=1$. Note that boron and sodium rates are identical within error and the rate decreases linearly with $a\left[\mathrm{SiO}_{2}(\mathrm{aq})\right]$ over most of the diagram. See text for details. crease slightly. This behavior is identical to the results reported by Abraitis et al. [10]. As more $\mathrm{Si}$ is added to the input solution, $\mathrm{Al}$ concentrations drop below detection levels and so silicic acid activity controls the dissolution rate, resulting in the linear decrease in rate over the majority of the diagram. These data suggest that the observed deviations from linearity observed with ILAW glass compositions are a consequence of $\mathrm{Na}^{+}-\mathrm{H}^{+}$exchange reactions, not inconsistency with the chemical affinity rate law itself.

Although ion exchange is the probable cause of observed deviations from the kinetic rate law (2), the available data do not permit a statistically meaningful selection between defining $K_{g}$ as in Grambow's model with a simple $\mathrm{SiO}_{2}$ polymorph or as a mixed $\mathrm{Al}-\mathrm{Si}$ activity product. Either approach provides an adequate fit to our data set. As a result, we will make a selection based on heuristic arguments.

As discussed above in some detail, when the concentration of dissolved $\mathrm{Si}$ is low, even small concentrations ( $<100$ micromolar) of $\mathrm{Al}$ causes dissolution rates to decrease. To account for this effect, Al may be included in the ion activity product, $Q$, or as an inhibitor species in the $\prod_{j} a_{j}^{\eta_{j}}$ term in Equation (2). However, in either case, if the concentration of $\mathrm{Al}$ is very low even 
though the concentration of Si is high, dissolution rates calculated via Equation (2) will be at or near the forward rate of reaction. Instead, SPFT results shown in Figure 14 demonstrate the opposite, i.e. the rate of dissolution is unaffected by the addition of $\mathrm{Al}$ in solutions containing high concentrations of Si. Moreover, it is highly probable that the disposal system environment would establish low Al concentrations because zeolites, a class of hydrous aluminosilicate mi nerals, ubiquitously form as reaction products with ILAW glasses (see Section 4.1.3.3). The large amount of excess Si available in the glass suggests that the fluids slowing percolating through the disposal system would be near saturation with respect to $\mathrm{SiO}_{2}$ polymorphs. Consequently, incorporation of $\mathrm{Al}$ species in the present form of the kinetic rate law would likely result in predicting erroneously high glass dissolution rates in reactive transport simulations of the disposal system. Consequently, we recommend using the simpler (Grambow) approach of assigning $K_{g}$ to amorphous silica until a better kinetic rate law for ILAW glasses can be developed. A correction to the rate law for the effect of ion exchange can be accommodated in the STORM code once the exchange rate has been determined. This is discussed in the next Section.

\subsubsection{Ion-Exchange Rate}

Sodium ion-exchange rate as a function of temperature can be obtained directly from the data shown in Figures 6 and 7. Using the data at high silicic acid activity, the normalized rate of boron release is subtracted from the sodium rate and then converted to moles of Na per unit area per time to yield the sodium exchange rate. Exchange rates for the four temperatures investigated are plotted on Figure 16. The regressed activation energy for $\mathrm{Na}^{+}-\mathrm{H}^{+}$exchange from LAWABP1 glass is $52.7 \pm 6.7 \mathrm{~kJ} \mathrm{~mol}^{-1}$, which is similar to the activation energy of $47.3 \mathrm{~kJ}$ $\mathrm{mol}^{-1}$ reported by Pederson [26] for sodium silicate glass. We note that on an Arrhenius diagram such as this, a correction factor for the change in solution $\mathrm{pH}$ should be applied. We have not yet completed measurements of $\mathrm{Na}$ ion exchange rate as a function of $\mathrm{pH}$ so this correction, if any, could not be applied.

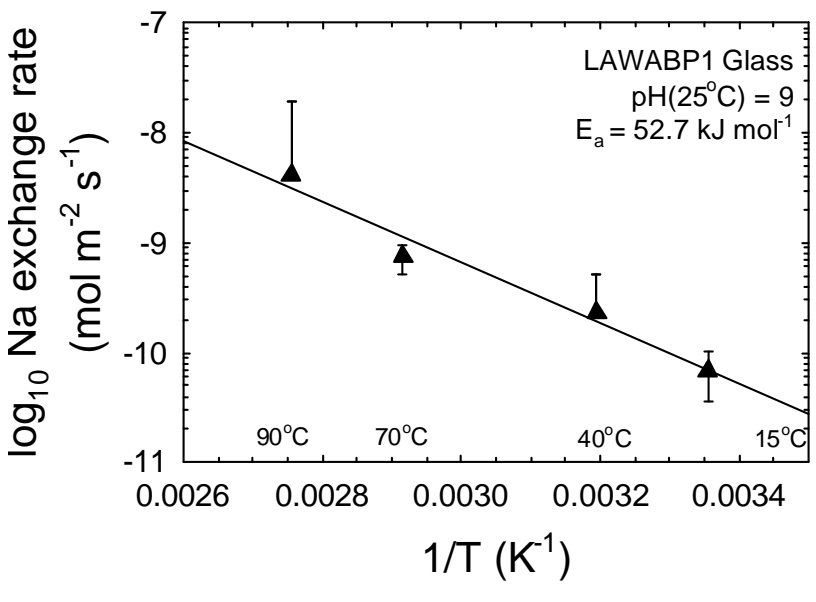

Figure 16. Sodium-H Exchange Rate Versus Reciprocal Temperature for LAWABP1 Glass. The slope of the line through the data indicates an activation energy of $52.7 \mathrm{~kJ} \mathrm{~mol}^{-1}$. 
Bunker [27] argues that the interstitial water in corrosion layers is buffered relative to the bulk solution $\mathrm{pH}$. This would tend to limit any changes in ion exchange rate over a narrow $\mathrm{pH}$ range. From the data in Figure 16, the sodium ion exchange rate at $15^{\circ} \mathrm{C}$, the likely repository temperature, can be estimated at $3.4 \times 10^{-11} \mathrm{~mol} \mathrm{~m}^{-2} \mathrm{~s}^{-1}$.

\subsubsection{Effects of Humic and Fulvic Acid}

Humic substances constitute $70-80 \% \mathrm{w} / \mathrm{w}$ of the organic matter in most soils [28]. Because humics have a strong ability to interact with metal ions, oxides, hydroxides, and minerals to form water-stable associations, investigators have suggested that humic acids may accelerate dissolution rates of silicate materials by attacking the $\mathrm{Si}-\mathrm{O}$ bond. For example, Bennett et al. [29]

found that dissolution rates of quartz are faster in the presence of humic acid at $\mathrm{pH}=7$ compared to rates in solutions containing no organic acids. Gin et al. [30] conducted batch experiments with R7T7 high-level waste glass in $\mathrm{pH} 7.3$ solutions containing up to $5 \mathrm{~g} / \mathrm{L}$ humic acid (a commercial humic acid product from Fluka). Dissolution rates based on B release increased by $4 \mathrm{X}$ in a $0.5 \mathrm{~g} / \mathrm{L}$ solution and by $6 \mathrm{X}$ in a $5 \mathrm{~g} / \mathrm{L}$ solution.

Determination of an appropriate concentration of humic acid for use in this study was hampered by an almost complete lack of pertinent data on concentrations of natural organic acids present in Hanford pore waters. Toste [31] obtained samples from a seepage trench near the NReactor and analyzed them for total organic carbon (TOC) and fractionated the carbon content into high and low molecular weight organics. Toste [31] found average TOC ranging between 2 to $3 \mathrm{mg} / \mathrm{L}$ and that most of the organic carbon (>75\%) was present as naturally occurring humic and fulvic acids.

Using Toste's study as a guide, we prepared a $50 \mathrm{mg} / \mathrm{L}$ humic acid solution from commercially-available materials (Aldrich Chemical, Inc.). Commercially available humic acid typically contains a sizeable fraction (9.3 to 33\%) of ash that contains Fe and Si among other elements. We separated the ash and humic acid by digesting the material in a concentrated $\mathrm{NaOH}-\mathrm{NaF}$ solution. The $\mathrm{NaF}$ is necessary to dissolve amorphous silica that may be present. Humic acid was then precipitated from solution by acidifying the solution with $\mathrm{HCl}$. Repeated washing, decanting, and centrifuging removed most of the residual $\mathrm{Na}$ from the humic acid. Aliquots of the sample were dried overnight and the precipitated humic acid crystals were collected. Humic acid solutions were made up by adding $50 \mathrm{mg}$ of the prepared humic acid to $1 \mathrm{~L}$ of deionized water. 
The solution $\mathrm{pH}$ was adjusted to $\mathrm{pH}=9$ using $0.05 \mathrm{M}$ THAM and a small quantity of nitric acid. Concurrent with two experiments using the humic acid solution, we ran two "control" experiments with a solution composition identical to the above, but lacking humic acid. Analyses of the starting solutions indicated the humic acid solution contained up to 2 ppm Na, probably a residual contamination from the digestion procedure. Thus, the background correction for this element was important. The experiments were run at $90^{\circ} \mathrm{C}$ for a week using flow-rates previously determined to be appropriate.

For experiments with fulvic acid, we used a well-characterized "Soil Fulvic Acid Standard" purchased from the Humic Substances Society. Fulvic acid solutions were made up by adding $10 \mathrm{mg} / \mathrm{L}$ (or $10 \mathrm{ppm}$ ) fulvic acid to DIW and $\mathrm{pH}$ adjusting to a value of 9. As in the case of the experiments with humic acid solutions, two "control" experiments were run in which solutions contained no fulvic acid.

\subsubsection{NMR Characterization}

The prepared humic acid was analyzed at room temperature with ${ }^{13} \mathrm{C}$ magic angle spinning nuclear magnetic resonance spectroscopy (MAS-NMR). The observed chemical shifts were referenced against an internal standard of Tetrakis (trimethylsilyl) silane. Spectra were obtained on a Varian VXR-300 spectrometer at 7.05 T using high-speed probes manufactured by Doty Scientific, Inc. Silicon nitride rotors were used to spin the samples at $5 \mathrm{kHz}$.

Figure 17 shows the measured peak intensities versus chemical shift. The large peak between 0 to $50 \mathrm{ppm}$ is assigned to saturated aliphatic carbons, aromatic and olefinic carbons are at 100 to $150 \mathrm{ppm}$, and carboxyl carbons are at 165 to $190 \mathrm{ppm}$. The MAS-NMR results are essentially identical to those reported by Malcolm and MacCarthy [32] for Aldrich humic acid. The data indicate a humic acid with relatively low population den-

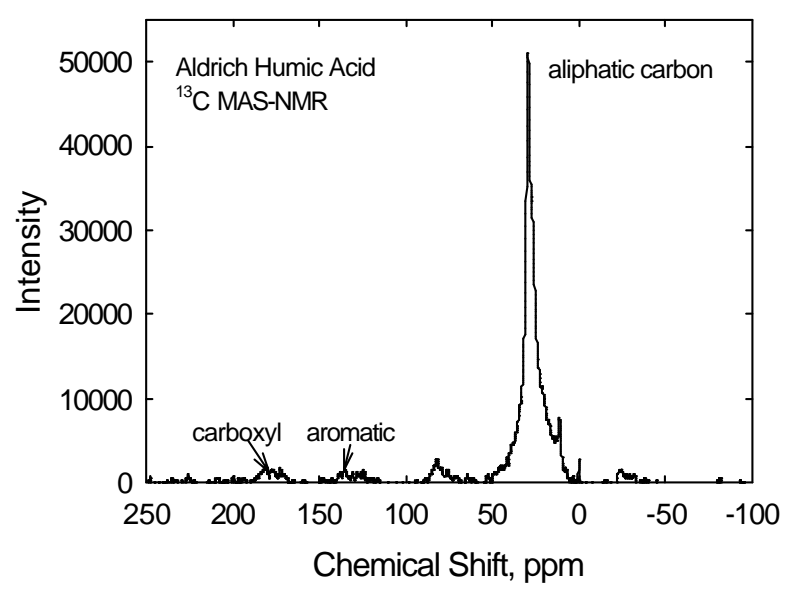

Figure 17. MAS-NMR Spectra of Aldrich $\mathrm{Hu}-$ mic Acid Used in SPFT Experiments sity of aromatic and carboxyl functional groups. This is important because the complexing power of humic and fulvic acids results largely from their content of $\mathrm{COOH}$, phenolic $\mathrm{OH}$, and 
$\mathrm{C}=\mathrm{O}$ groups. Humic acid is not a single pure compound but a heterogeneous mixture of organic substances [33]. Natural humic acids have wide variations in molecular weight, numbers of functional groups, and extent of polymerization [32]. We were not able to locate reported spectroscopic analyses of natural humics in Hanford soils. Consequently, the degree of departure of the characteristics of the Aldrich humic acid used in our tests from naturally occurring humics at Hanford could not be assessed.

\subsubsection{Dissolution Rate Results}

Figure 18A shows that dissolution rates computed from effluent concentration of B, and $\mathrm{Na}$ are identical within experimental error $(0.2 \log$ units or $35 \%)$ in the pure buffer and humic acid solution. Concentrations of $\mathrm{Al}$, and therefore rates based upon $\mathrm{Al}$, are syste matically higher in the solutions containing humic acid. This effect is probably due to chelating of $\mathrm{Al}$ by humic acids. In any event, there is no systematic difference in dissolution rates based on boron concentrations. Similarly, Figure 18B, indicates no differences in rates in the fulvic acid solution as compared with the pure buffer solution.

Although these experiments suggest that humic (and fulvic) acids do not significantly accelerate dissolution rates, the commercial humic acid used in these experiments contains
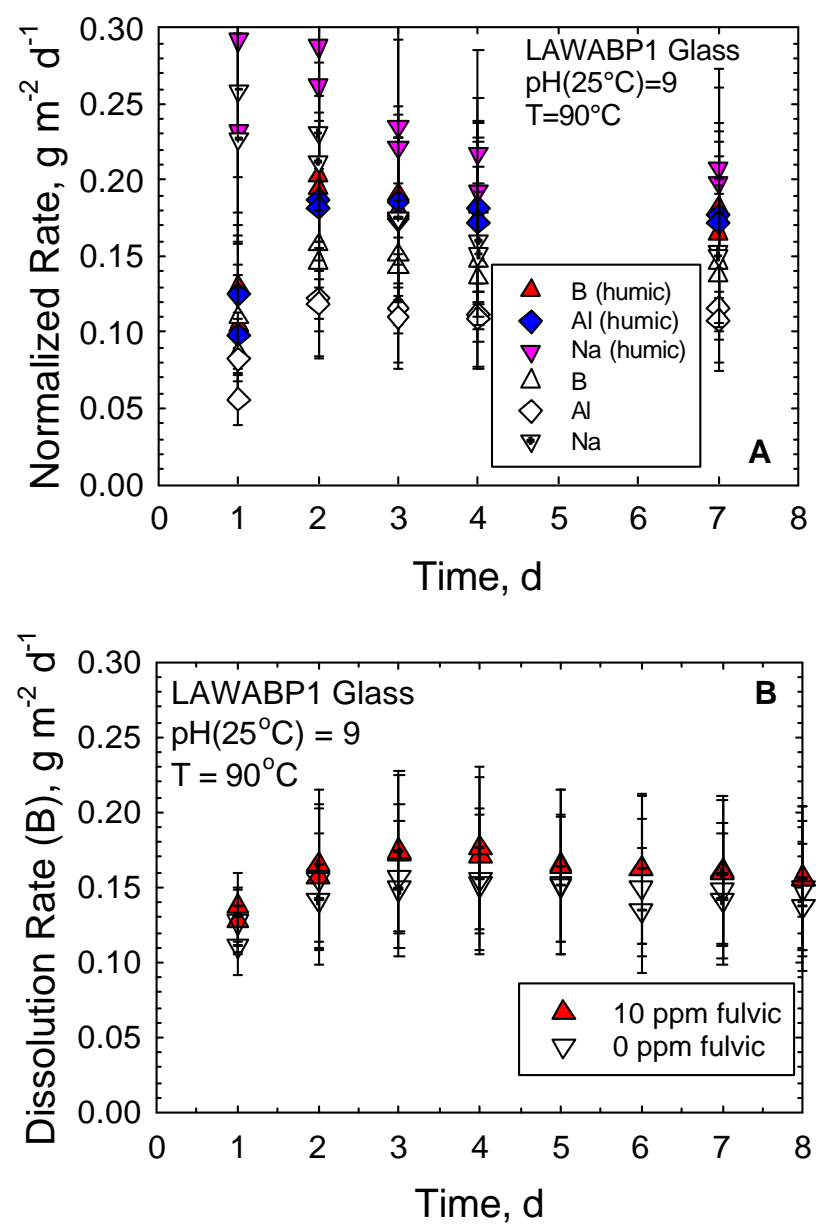

Figure 18. Dissolution Rate (Based on $\mathrm{B}, \mathrm{Al}$, or Na) Versus Time for Experiments With and Without Humic Acid (A) and Fulvic Acid (B). few reactive functional groups, so that a natural humic acid could give different results. However, we compensated for this to some extent by using a much higher concentration of humic acid $(50 \mathrm{ppm})$ than is likely to exist in Hanford pore waters. Consequently, we believe it unlikely that a different humic acid would have a significant effect on dissolution rates at concentrations typical of Hanford pore waters. 


\subsection{RESULTS FOR HLP-31 GLASS}

A limited set of SPFT experiments has been conducted with the higher waste loading glass, HLP-31. This glass will serve as a sensitivity case for the 2001 ILAW PA. The SPFT experiments were doped with Si up to saturation with respect to amorphous silica as was described previously for LAWABP1 glass. The results, shown in Figure 19, are quite surprising in that the dissolution rate (based on boron) shows no evidence of decreasing as the activity of silicic acid increases. Moreover, the release of $\mathrm{Na}$ appears

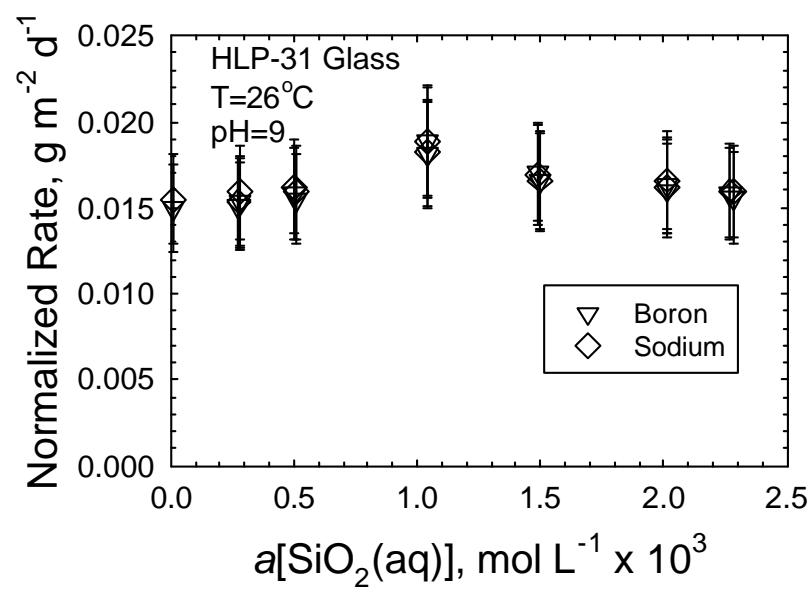

Figure 19. Dissolution Rate of HLP-31 Glass Versus Activity of Silicic Acid for Conditions of $\mathrm{pH}=9, \mathrm{~T}=26^{\circ} \mathrm{C}$. Increasing concentration of $\mathrm{Si}$ has no impact on either $\mathrm{B}$ or Na release rate. to be congruent with B over the concentration interval of input Si. Consequently, alkali ion exchange does not provide an explanation for this unusual behavior. Lack of evidence for ion exchange with this glass is surprising since HLP-31 contains significantly more Na than is needed to satisfy the number of $\mathrm{BO}_{4}{ }^{-}$and $\mathrm{AlO}_{4}{ }^{-}$units in the glass. The excess sodium (in both the HLP31 and LAWABP1 compositions) is accommodated by formation of non-bridging oxygen (NBO) sites and we argued previously that these sodium atoms are especially vulnerable to alkali-hydrogen exchange.

Averaging the dissolution rate data in Figure 19 gives a forward reaction rate for HLP-31 glass of $0.016 \mathrm{~g} \mathrm{~m}^{-2} \mathrm{~d}^{-1}$. This rate is 10 to $15 \mathrm{X}$ faster than the forward reaction rate for LAWABP1 glass at this same temperature and $\mathrm{pH}$. Similar measurements with a wide variety of other silicate glass compositions, some containing no alkali, have all given forward reaction rates that are within the experimental error estimate of 35\%, as shown in Figure 20. Consequently, we anticipate little or no compositional dependence for forward reaction rates. Yet, the forward reaction rate of HLP-31 glass is much higher than any other silicate-based glass we have studied. 
Microscopic phase separation (see Figure 1) is most probably cause of the unusual dissolution behavior observed with HLP-31 glass. The $\mathrm{R}$ ratio [mo$\operatorname{lar}\left(\mathrm{Na}_{2} \mathrm{O}+\mathrm{K}_{2} \mathrm{O}\right) /\left(\mathrm{Al}_{2} \mathrm{O}_{3}+\mathrm{B}_{2} \mathrm{O}_{3}\right.$ $\left.\left.+\mathrm{Fe}_{2} \mathrm{O}_{3}\right)\right]$ of HLP-31 is 1.6. According to Fleet and Muthupari [34], in glasses with $\mathrm{R}>1$, the additional $\mathrm{Na}_{2} \mathrm{O}$ is accommodated in the glass structure by forming NBO sites with both silicate and trigonal borate groups. Agglomeration of these borate groups into borate rich regions would leave portions

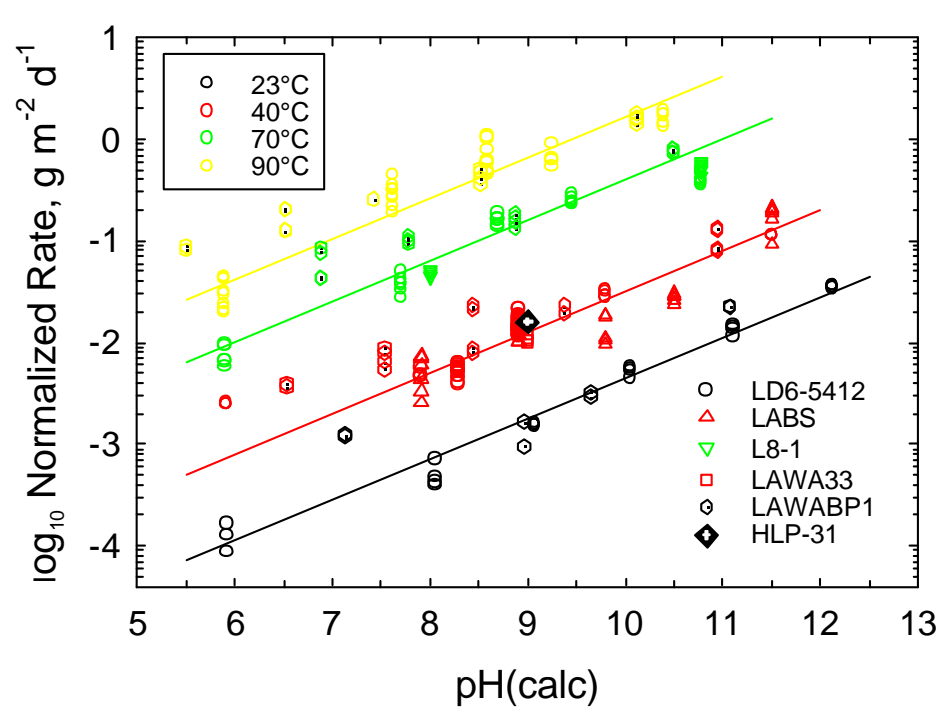

Figure 20. Forward Reaction Rate as a Function of Temperature and Solution $\mathrm{pH}$ for a Wide Variety of Borosilicate Glasses. HLP-31 glass stands out as the most reactive glass at $23^{\circ} \mathrm{C}$.

of the glass susceptible to hydrolysis reactions. Dissolution and release of $\mathrm{Na}$ and $\mathrm{B}$ from these regions would not follow a conventional theory of glass dissolution behavior. In any event, to model the performance of this glass in the disposal system, the dissolution rate of HLP-31 should not be allowed to change as a function of the silicic acid concentration in the disposal system pore water, i.e. the rate should be assigned a constant value. Assuming that the activation energy of dissolution is the same as for LAWABP1 glass, this gives a dissolution rate constant at $15^{\circ} \mathrm{C}$ of $0.0056 \mathrm{~g} \mathrm{~m}^{-2} \mathrm{~d}^{-1}$. Experiments are still in progress to determine the $\mathrm{pH}$-dependence of the dissolution rate for this glass. 


\subsection{CHEMICAL REACTION NETWORK}

Having determined the kinetic rate law parameters for LAWABP1 and HLP-31 glasses in the previous Section (3.0), the next set of required data to conduct source-term calculations with the STORM code is 1) a set of secondary phases that form from the long-term weathering of these glasses in the disposal system environment, and 2) the precipitation-dissolution rate and/or solubility product for each of these phases. Unfortunately, the suite of weathering products that will form as a consequence of the glass-water reaction cannot be determined a priori. As discussed by McGrail et al. [1], laboratory tests are used to simulate and accelerate the weathering process. Two types of tests are used: 1) PUF tests, and 2) vapor hydration tests.

\section{1 $\quad$ PUF TESTS}

In previous papers [35-36], equipment configurations for the PUF system have been described. A significant number of improvements have been made since these papers were published, mainly focused on consolidating the support equipment and electronics into a single unit. Still, the basic test apparatus consists of a column packed with crushed test material (or materials) of a known particle size and density, a computer data acquisition and control system, fluid pump, and electronic sensors, as illustrated in Figure 21. The column is fabricated from polyetheretherketone (PEEK), which is chemically inert so that dissolution reactions are not influenced by interaction with the column. A porous titanium plate with nominal pore size of $0.2 \mu \mathrm{m}$ is sealed in the bottom of the column to ensure an adequate pressure differential for the conductance of fluid while operating under unsaturated conditions [37]. Titanium was chosen because it is highly corrosion resistant and has excellent wetting properties. When water saturated, the porous plate allows water but not air to flow through it, as long as the applied pressure differential does not exceed the air entry relief pressure, or "bubble pressure," of the plate. The computer control system runs LabVIEW ${ }^{\mathrm{TM}}$ (National Instruments Corporation, Austin, Texas) software for logging test data to disk from several thermocouples, pressure sensors, inline sensors for effluent $\mathrm{pH}$ and conductivity. The column is suspended from an electronic strain gauge to accurately track water mass balance and saturation level. The column also includes a "PUF port," which is an electronically actuated valve that periodically vents the column gases. The purpose of column venting is to prevent reduction in the partial pressure of important gases, especially $\mathrm{O}_{2}$ and $\mathrm{CO}_{2}$, which may be consumed in a variety of chemical reactions. 

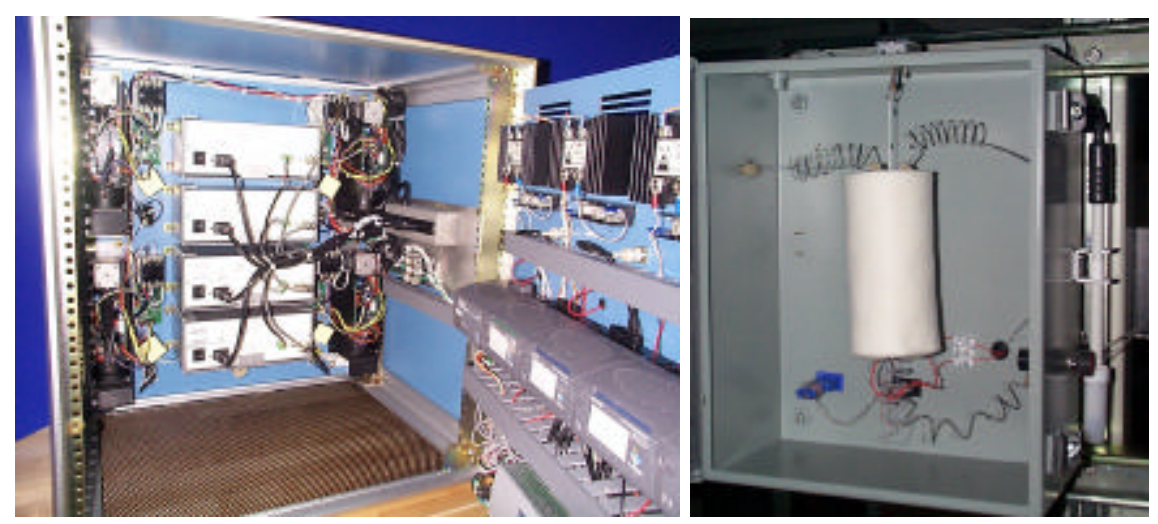

Figure 21. Picture of PUF System Hardware (Patent \#5974859)

\subsubsection{Materials}

Results from PUF testing of three representative ILAW glasses will be discussed: LAWABP1, HLP-31, and LAWA44 glasses. The composition of LAWABP1 and HLP-31 glasses are given in Table 2. LAWA44 is a representative BNFL, Inc. glass developed by Dr. Ian Pegg at the Catholic University of America. The composition of LAWA44 glass was considered proprietary at the time this report was published but it has a 20 mass $\% \mathrm{Na}_{2} \mathrm{O}$ content, identical to LAWABP1.

Crushed glass was prepared following the procedure detailed by the American Society for Testing and Materials [38]. The glass was crushed manually and sieved to separate the 425- to $250-\mu \mathrm{m}$ size fraction (-40+60 mesh). The crushed and sieved glass was then washed ultrasonically with demineralized water and ethanol to remove fines, and then dried. Representative samples of the crushed, sieved, and washed glass were surveyed with a scanning electron microscope (SEM) to verify that the size of the glass grains was consistent with the sieved size fraction and that fines had been removed. The specific surface area of crushed glass was estimated by assuming particles to be spheres having radii equal to the average opening of the sieves, as was discussed previously.

\subsubsection{PUF Test Procedure}

The PUF experiments were performed at nominal flow rate of $2.0 \mathrm{~mL} / \mathrm{d}$ and a temperature of $99^{\circ} \mathrm{C}$. Each column was packed with the crushed and cleaned glass, giving an initial porosity of approximately $0.40 \pm 0.03$, and then vacuum saturated with water at ambient te mperature. A temperature controller was programmed to heat the column to $99^{\circ} \mathrm{C}$ in approximately $1 \mathrm{~h}$ 
$\left(1^{\circ} \mathrm{C} / \mathrm{min}\right)$. The column was allowed to initially desaturate during heating by gravity drainage and was also vented periodically to maintain an internal pressure less than the bubble pressure of the porous plate. After reaching $99^{\circ} \mathrm{C}$, the influent valve was opened, and influent and effluent were set to their respective flow rates. Column venting was set to occur once an hour. Effluent samples were collected in a receiving vessel, which was periodically drained into tared vials from which samples were extracted and acidified for elemental analysis by ICP-OES and ICPMS. The ICP-MS was calibrated with certified standards prior to each series of analyses.

At the time of this writing, only the experiment with LAWABP1 glass has been terminated. After test termination, reacted solids were removed by carefully scraping material out of the column at intervals of calibrated depth. The removed solids were placed in individual containers and the samples were allowed to dry in air. Selected samples were then analyzed with SEM and $\mathrm{x}$-ray diffraction (XRD). A few samples of the reacted glass particles were also mounted in an epoxy resin that was then ground using 600-grit $\mathrm{SiC}$ paper to permit viewing in cross section the particles and any surface layers.

\subsubsection{Results for LAWA Series Glasses}

Results from the computer-monitored test metrics for LAWABP1 and LAWA44 glasses are shown in Figure 22. At about $150 \mathrm{~d}$ in the test with LAWA44 glass, an electrical problem developed with the conductivity sensor. Consequently, the electrical conductivity data are inaccurate after this time period. Because the sensor data are noisy, the data were smoothed using a bisquare weighting method where the smoothed data point, $y_{s}$, is given by $y_{s}=\left(1-\omega^{2}\right)^{2}$. The parameter $\omega$ is a weighting coefficient calculated from a window surrounding the smoothing location in the set of the independent variables. A low-order polynomial regression (order 2 in this case) is used to compute $\omega$ for each smoothed value. The smoothed data are provided as lines in Figure 22. 

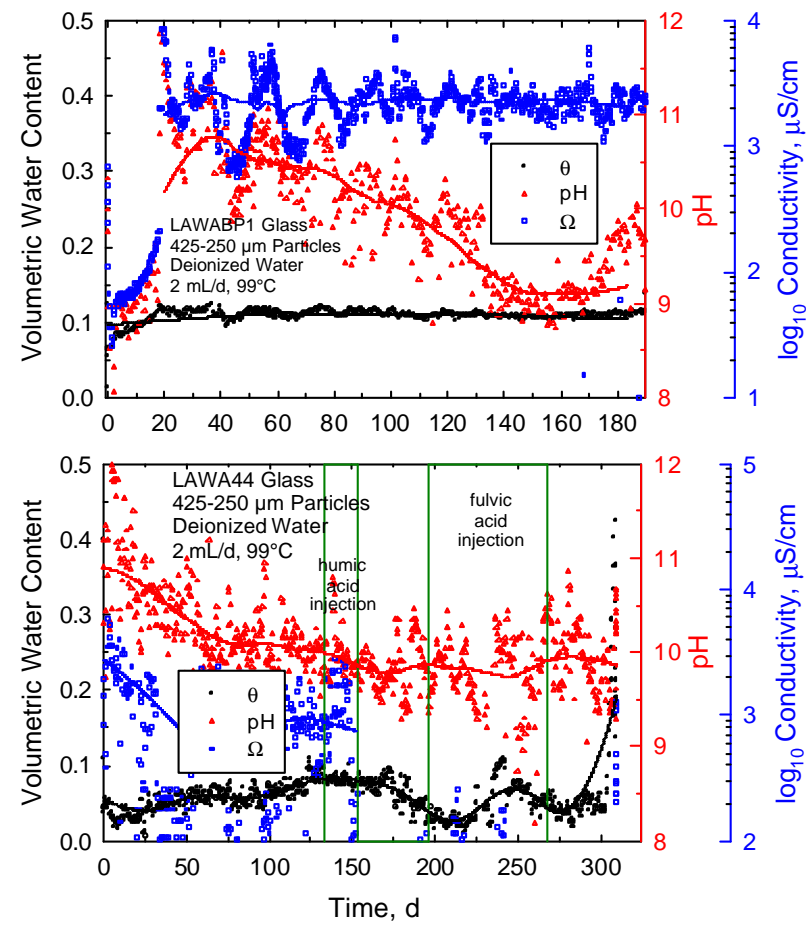

Figure 22. Computer Monitored Test Metrics From PUF Tests with LAWA Series of Glasses. Lines are bi-square smoothed fits to the raw data. The vertical lines give the period where a $50 \mathrm{mg} / \mathrm{L}$ humic acid solution was injected instead of deionized water.

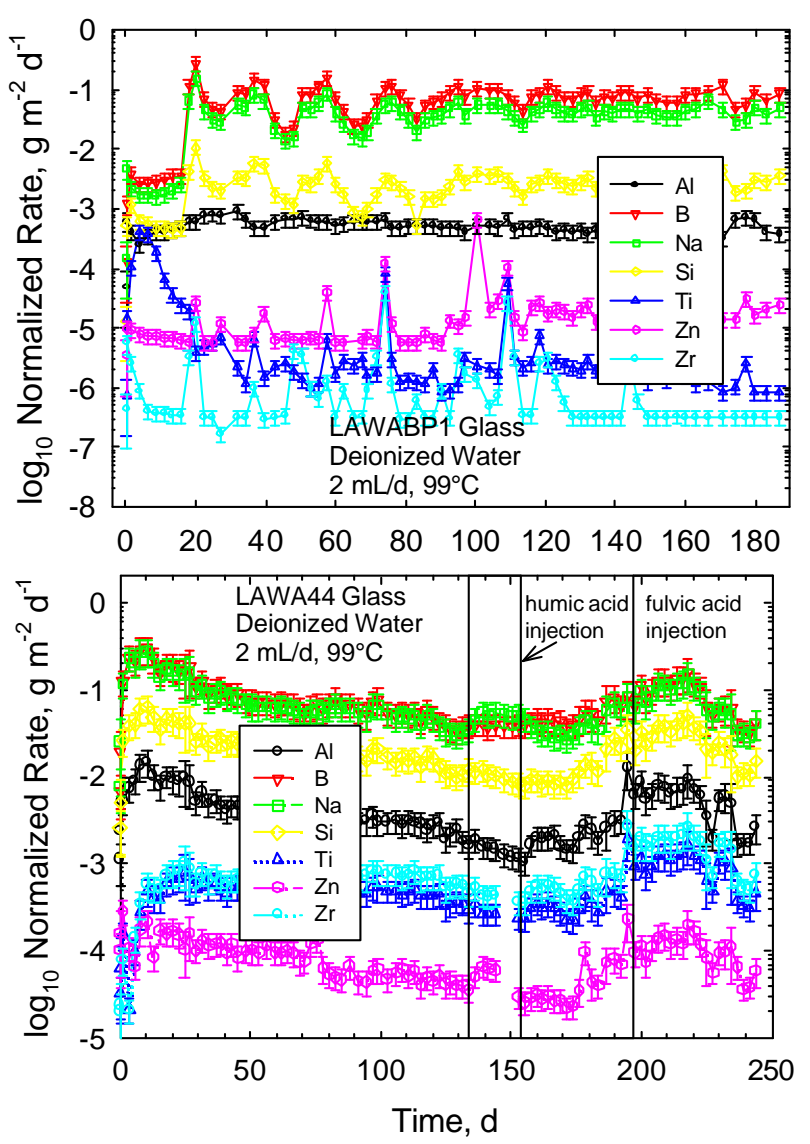

Figure 23. Normalized Release Rate for Selected Elements in PUF Tests with LAWA Series of Glasses

A comparison of glass dissolution rates based on B release between LAWABP1 and the LAWA44 glass shows that both glasses are performing well with the rate just before the test with LAWABP1 glass was terminated at $0.1 \mathrm{~g} \mathrm{~m}^{-2} \mathrm{~d}^{-1}$ and for LAWA44 glass (test still in progress) at $0.06 \mathrm{~g} \mathrm{~m}^{-2} \mathrm{~d}^{-1}$. The interested reader should consult McGrail et al. [39] for description of the formula used to calculated normalized release rate in PUF tests. Also note that the dissolution rate of LAWABP1 glass in the PUF test is essentially identical to the dissolution rate measured in SPFT experiments in solutions near saturation with respect to amorphous silica (see Figure 8).

\subsubsection{Humic and Fulvic Acid Solutions}

At approximately $135 \mathrm{~d}$, the deionized water influent in the PUF test with LAWA44 glass was changed out for the $50 \mathrm{mg} / \mathrm{L}$ humic acid solution, which was described previously (Section 3.2.6). As is evident in Figure 22, no change in electrical conductivity or solution $\mathrm{pH}$ occurred immediately after the change to the humic acid solution. No change in the dissolution rate of the 
LAWA44 glass is evident either from the effluent chemical analysis, as shown in Figure 23, although the higher Na content of the humic acid solution is clearly detected over the injection period. Essentially identical results were obtained with the fulvic acid solution, i.e. no statistically significant change in dissolution rate was observed. These results are in accord with what was observed in SPFT experiments with the same organic acids (see Section 3.2.6).

\subsubsection{LAWABP1 Water Mass Distri- bution}

After termination of the PUF test with LAWABP1 glass, the reacted solids were subsampled as found (loose and moist particles) at $5 \mathrm{~mm}$ intervals. These samples were analyzed for moisture content by drying in glass vials at room temperature in a sealed can with $\mathrm{CaSO}_{4}$ desiccant. Samples were dried until a constant mass was obtained. The results are shown in

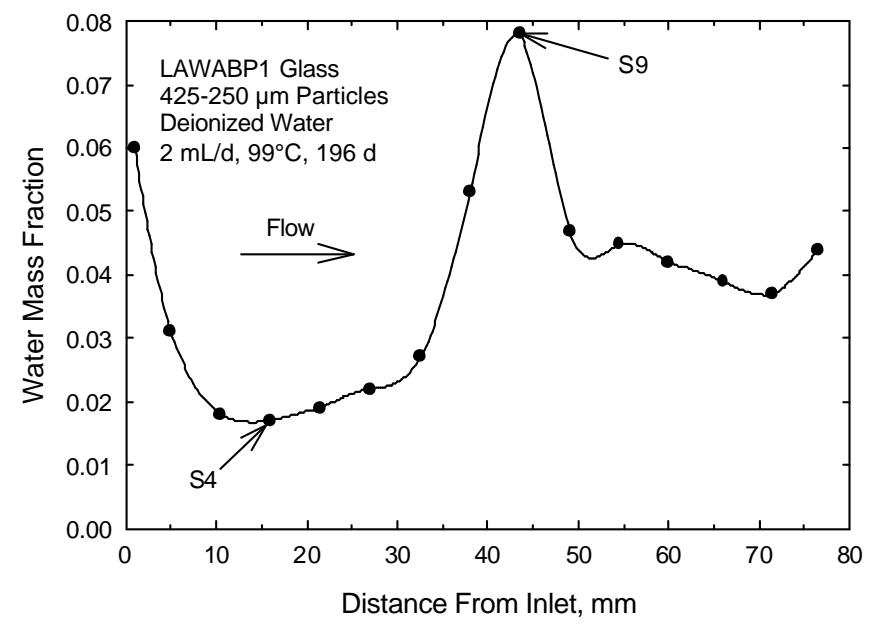

Figure 24. Water Mass Distribution in Reacted Solids From PUF Test with LAWABP1 Glass Figure 24.

The first three data points likely represent an imbibition profile as water drips from the fluid inlet onto the top of the porous glass bed. The data show peak water content at about $45 \mathrm{~mm}$ downstream (sample S9) from the fluid inlet. As will be shown in the next section, this sample also contains the greatest volume percentage of crystalline phases. Consequently, the larger water mass associated with the sample is likely a combination of interstitial water trapped in the tighter pore space and as waters of hydration associated with the secondary minerals formed in this region of the column. Sample S9 is indicative of a true precipitation front where water mass has accumulated in alteration products.

\subsubsection{Solid Phase Analyses}

Optical photographs (Figure 25) taken on samples S4 and S9 show how the grains from sample S4 appear almost pristine whereas most of the grains from sample S9 are coated with alteration products. The distribution of crystalline phases as a function of position in the PUF column was examined by powder x-ray diffraction (XRD). Although this method is not very sensitive, 


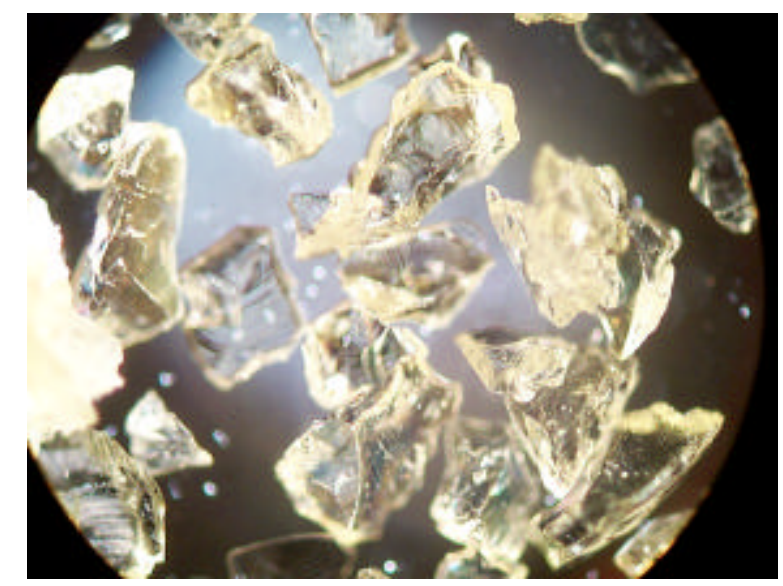

S4

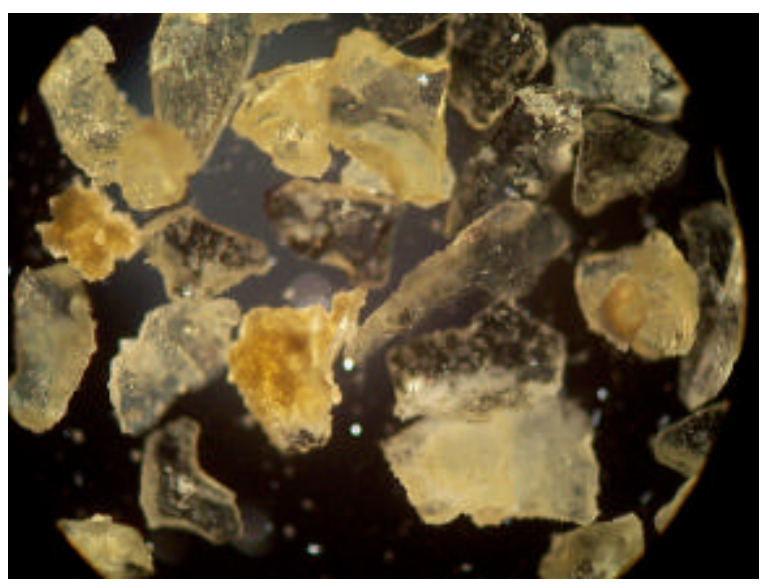

S9

Figure 25. Optical Photos of LAWABP1 Glass Samples S4 and S9 After $190 \mathrm{~d}$ of Reaction in PUF Test at $99^{\circ} \mathrm{C}$ and $2 \mathrm{~mL} / \mathrm{d}$ Flow Rate

requiring 10 vol\% or more crystallinity to produce a diffraction pattern, the results in Figure 26 clearly show the higher concentration of crystalline phases near samples S9 and S11. Overlapping peak positions associated with a number of $\mathrm{Na}-$ aluminosilicate phases makes quantitative pattern matching with an individual phase difficult. However, the patterns are consistent with the presence of herschelite $\left[(\mathrm{Na}, \mathrm{K}) \mathrm{AlSi}_{2} \mathrm{O}_{6} \cdot 3 \mathrm{H}_{2} \mathrm{O}\right]$, analcime $\left[\mathrm{NaAlSi}_{2} \mathrm{O}_{6} \mathrm{H}_{2} \mathrm{O}\right]$, and kaolinite $\left[\mathrm{Al}_{2} \mathrm{Si}_{2} \mathrm{O}_{5}(\mathrm{OH})_{4}\right]$.

SEM analyses of sample S9 reveals grains coated with an alteration layer (see highlighted area in Figure 27a) and several crystalline alteration phases. EDXS shows that Phase 1 is a mixed Na-K aluminosilicate and the crystal morphology clearly identifies it as herschelite. EDS analysis of Phase 2

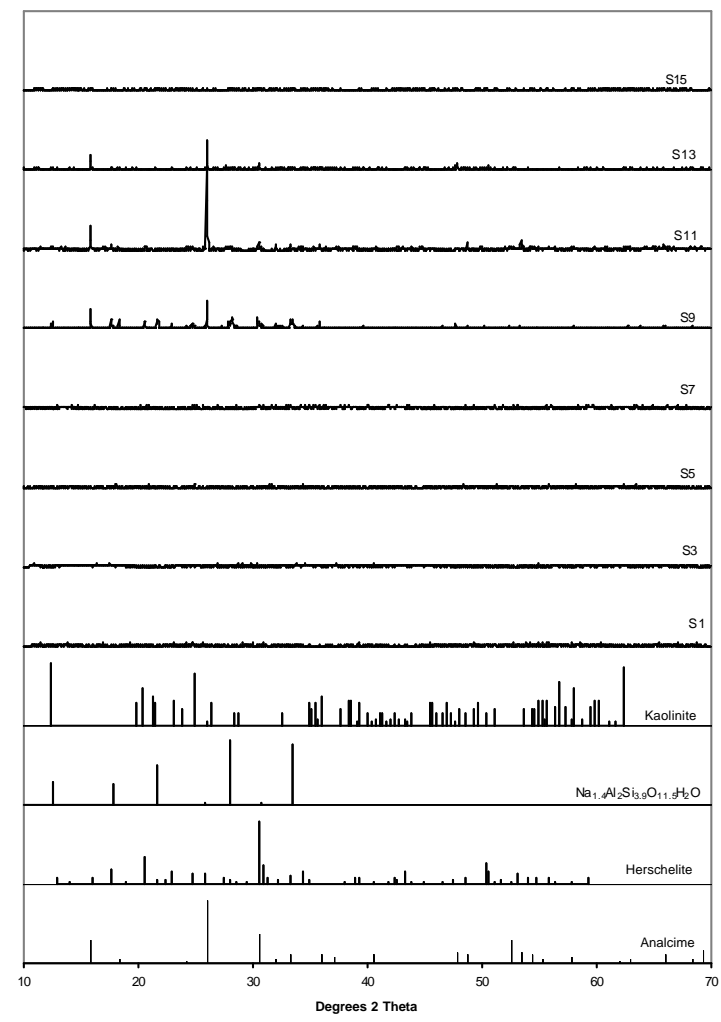

Figure 26. XRD Analyses of PUF Reacted LAWABP1 Glass Samples shows it to be a pure Na-aluminosilicate and the crystal morphology is consistent with analcime. Phase 3 comprises the bulk of the alteration layer on the glass. EDS analysis indicates that the phase is enriched in $\mathrm{Fe}, \mathrm{Mg}, \mathrm{Zn}$, and $\mathrm{Ti}$ and is most likely a nontronitic clay. 

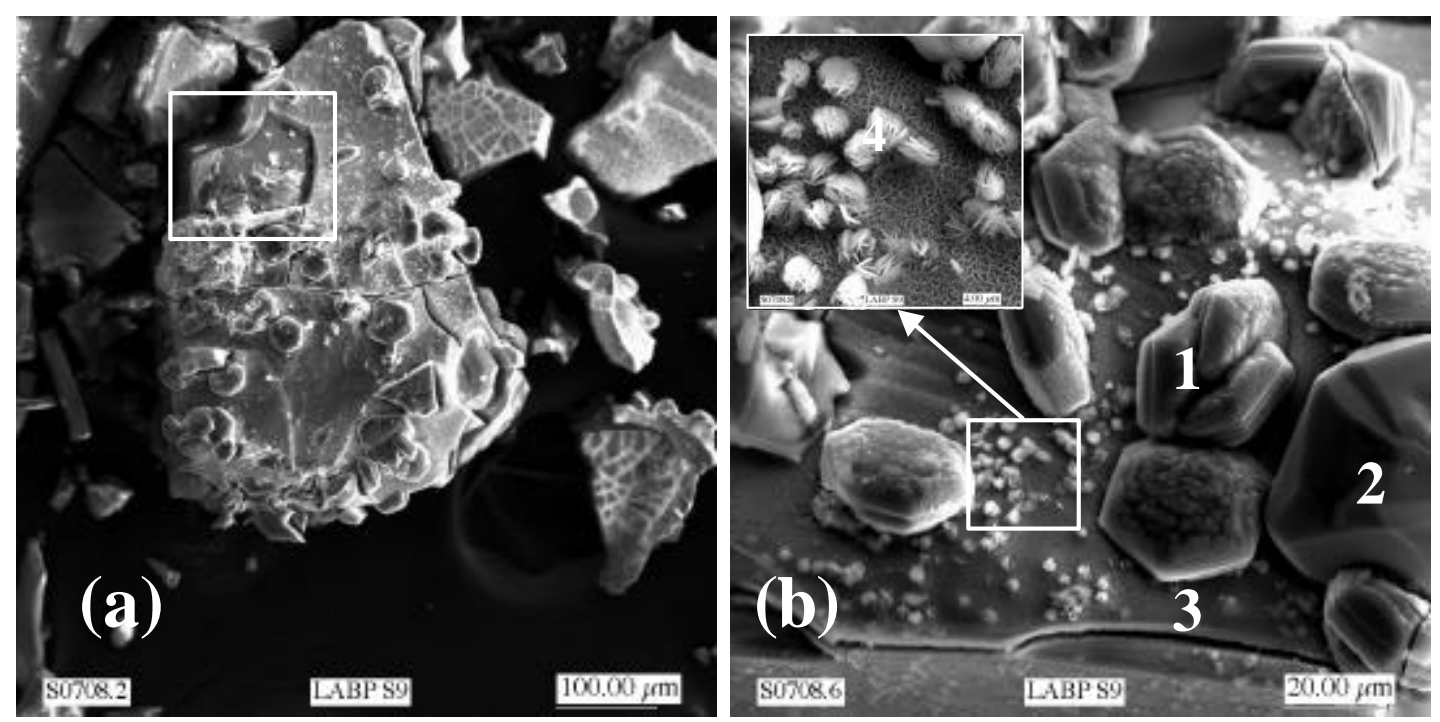

Figure 27. SEM Photos of Reacted LAWABP1 Glass Grains From Sample S9

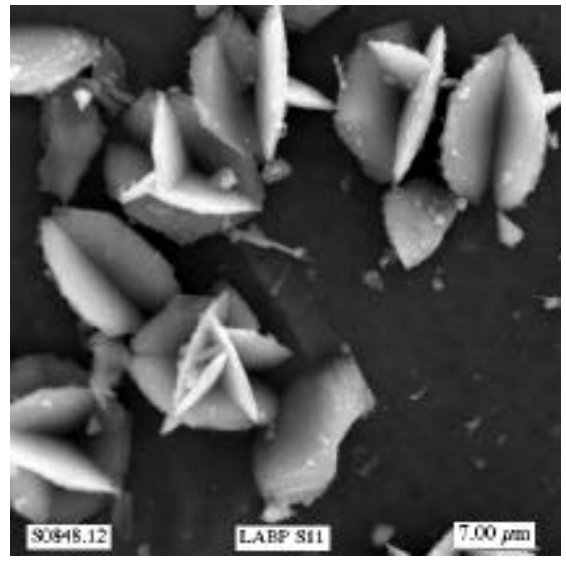

Figure 28. Kaolinite Crystals Found on PUF Reacted LAWABP1 Glass Sample S11

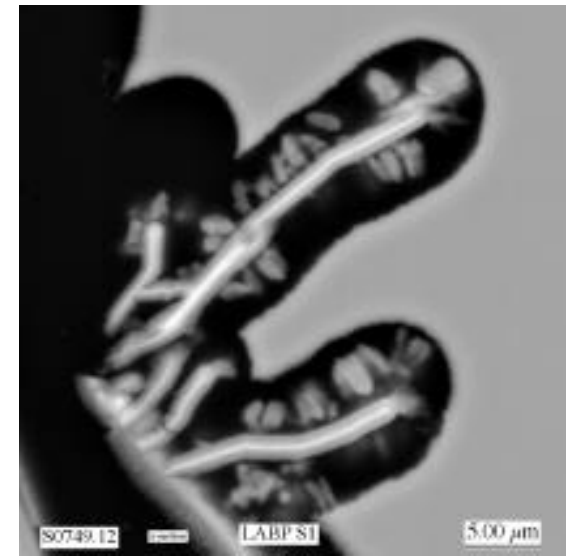

Figure 29. Aluminosilicate Phase Shown in Cross-Section in PUF Reacted LAWABP1 Sample S1

Embedded in the clay layer are also small crystals with plate-like morphology (see inset of Figure 27b). This phase was isolated in sample S11 as shown in Figure 28. The morphology of the phase and EDS analysis identify it as kaolinite, which was conclusively confirmed by the selected area electron diffraction in the TEM. TEM analyses also identified anatase $\left(\mathrm{TiO}_{2}\right)$ and sauconite $\left[\mathrm{Na}_{0.3} \mathrm{Zn}_{3}(\mathrm{Si}, \mathrm{Al})_{4} \mathrm{O}_{10}(\mathrm{OH})_{2} \cdot 4 \mathrm{H}_{2} \mathrm{O}\right]$ in sample $\mathrm{S} 11$.

Although the XRD analyses showed no crystalline phases in sample S1 (taken from near the top of the column), SEM analyses showed that small amounts of crystalline phases were present at isolated locations. EDS analyses showed these phases to be a Na-aluminosilicate compound. 
As is shown in Figure 29, the mode of attack in this region appears highly localized in contrast with the morphology in the other samples, which had more uniform corrosion layers of approximately constant thickness.

The PUF test with LAWA44 glass remains in progress at the time this report was drafted. Consequently, no reacted solid phase analyses are yet available.

\subsubsection{Results for HLP-31 Glass}

Results from the computer monitored test metrics from the test with HLP-31 glass are shown in Figure 30. The data were current as of the time this report was written; this test is still in progress. The large drop in $\mathrm{pH}$ and electrical conductivity at approximately $400 \mathrm{~d}$ was due to the inadvertent interruption of air pressure to the column for several days. This caused

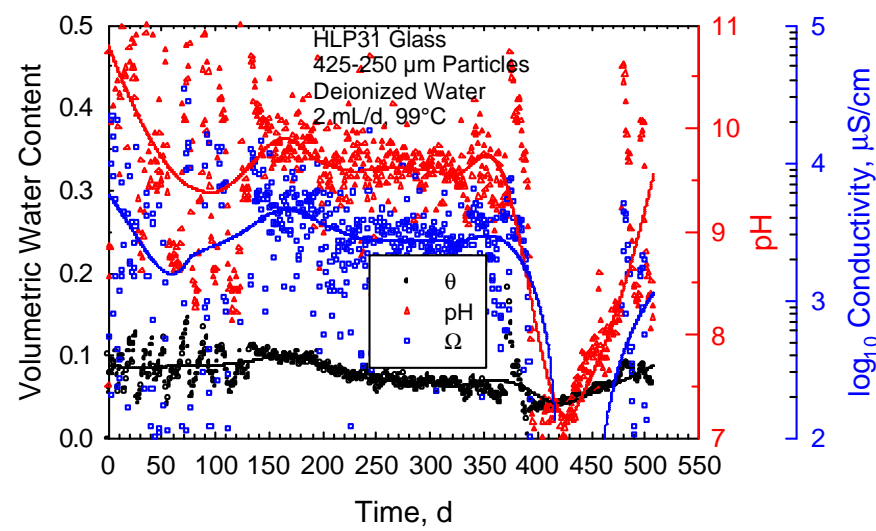

Figure 30. Computer Monitored Test Metrics From PUF Test with HLP-31 Glass. Lines are bi-square smoothed fits to the raw data. the effluent flow rate to drop to very low values and the water content to rise rapidly to near $70 \%$ of saturation. Once air pressure was restored, the effluent chemistry and water content began slowly returning to nominal values.

Results from effluent chemical analyses are shown in Figure 31. Differential rates of release are observed for the major glass components, which reflects their solubility behavior in water. Zinc, Zr, and Ti all form very insoluble hydroxides, which controls their release rate. In contrast, $\mathrm{B}$ and $\mathrm{Na}$ are highly soluble, and so have the highest elemental release rates. Bulk dissolution behavior is typically indexed by the rate of $\mathrm{B}$ release, as no solid phases are expected to form that would affect its solution concentration. Based on the B release data prior to the air pressure interrup-

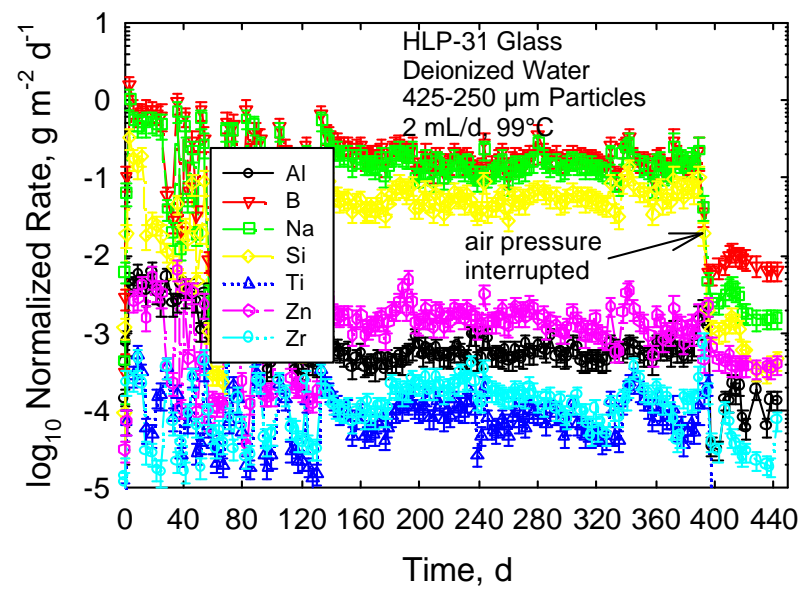

Figure 31. Normalized Release Rate for Selected Elements in PUF Test with HLP-31 Glass 
tion, HLP-31 glass is dissolving at about $0.4 \mathrm{~g} \mathrm{~m}^{-2} \mathrm{~d}^{-1}$, which is approximately 4 to $5 \mathrm{X}$ faster than observed for LAWABP1 and LAWA44 glasses (see Figure 23). The PUF test results are in accord with the previously discussed observations from SPFT experiments with HLP-31 glass. The higher $\mathrm{Na}_{2} \mathrm{O}$ loading (23 mass\%) of HLP-31 glass as compared with the LAWABP1 and LAWA44 glasses (20 mass\%) clearly results in a less durable glass.

\subsection{VAPOR HYDRATION TESTS}

In the vapor-phase hydration test, VHT, monolithic samples are exposed to saturated water vapor at elevated temperatures (typically $100^{\circ} \mathrm{C}$ to $300^{\circ} \mathrm{C}$ ) in a sealed vessel as shown in Figure 32. At relative humidity $(\mathrm{RH})$ above about $80 \%$, a thin film of water condenses on the sample. The thickness of the film increases with the $\mathrm{RH}$, and it is in this film that the glass corrodes. The thick-

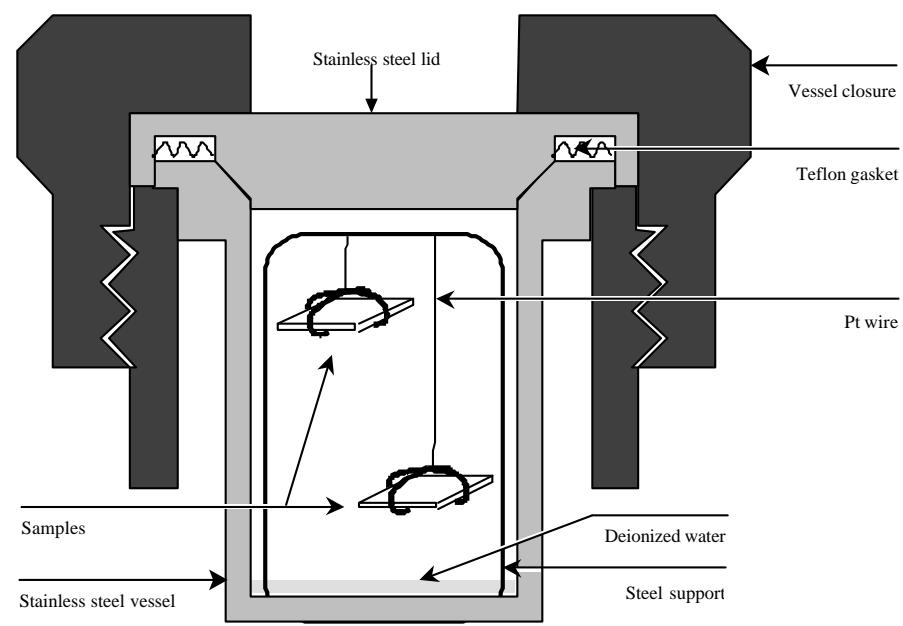

Figure 32. Schematic of Apparatus for conducting Vapor-phase Hydration Test ness of the film determines the effective $\mathrm{S} / \mathrm{V}$ ratio of the system; for a uniform layer, the S/V ratio is simply the inverse of the thickness of the film. Most VHTs have been performed in 100\% relative humidity at temperatures above $100^{\circ} \mathrm{C}$, although tests have been conducted at lower humidities and temperatures. At the completion of a test, the sample is removed from the vessel, and the reacted surface is analyzed. Discrete precipitated crystalline phases usually form when the sample corrodes. The solution evaporates from the sample when the test is terminated and is not available for analysis. This precludes using the test to evaluate and test models of glass corrosion behavior, which require detailed measurements of the solution composition in contact with the glass. 


\subsection{1 $\quad \underline{\text { VHT Procedures }}$}

The VHTs were performed according to a PNNL technical procedure. ${ }^{1}$ Samples with dimensions 10x10x1.5 mm are prepared from heat-treated glass bars using diamond impregnated saw. All sides are polished to 600 grit surface finish using SiC paper. Samples, stainless steel vessels, lids, and supports are cleaned and samples are suspended from a stainless steel supports on Pt wire. The amount of deionized water needed to saturate the inside of the vessel at given te mperature (plus $0.05 \mathrm{ml}$ excess of water, which is allowed to condense on samples surface) is added to the vessel. The sealed vessel is held at constant temperature in a convection oven for a preset time. After the test termination, samples are removed from the vessel and examined for presence of secondary phases first by visual observation and optical microscopy. Amount of glass dissolved is determined by measuring the thickness of remaining unaltered glass as viewed in cross section with an optical microscope equipped with image analysis software. The alteration products are identified with X-ray diffraction (XRD) and scanning electron microscopy (SEM) with energy dispersive spectroscopy (EDS).

\subsubsection{Results}

Corrosion rates reported by Shulz et al. [40] as a function of temperature for HLP-31, LAWABP1, and LAWA44 glasses are provided in Table
Table 5. VHT Corrosion Rate Summary. Rates in $\mathrm{g} \mathrm{m}^{-2} \mathrm{~d}^{-1}, \mathrm{E}_{\mathrm{a}}$ in $\mathrm{kJ} / \mathrm{mol}$.

\begin{tabular}{|c|c|c|c|c|}
\hline Glass ID & \multicolumn{4}{|c|}{$150^{\circ} \mathrm{C} 200^{\circ} \mathrm{C} 250^{\circ} \mathrm{C} 300^{\circ} \mathrm{C}$} \\
\hline$\overline{\text { HLP-31 }}$ & & 78.3 & & \\
\hline LAWABP1 & 3.7 & 4.8 & 44.2 & 336.4 \\
\hline LAWA44 & & 5.2 & 102.9 & 603.0 \\
\hline
\end{tabular}

5. Note that these results represent the current status of testing and some rates may change as new data become available. Shulz et al. [40] also report on the alteration phases formed on these glasses and these are provided in Table 6. Analcime and $\mathrm{NaTiSi}_{2} \mathrm{O}_{6}$ were the major alteration phases identified with each glass. Phillipsite $\left[(\mathrm{K}, \mathrm{Na})_{2}(\mathrm{Si}, \mathrm{Al})_{8} \mathrm{O}_{16} \cdot 4 \mathrm{H}_{2} \mathrm{O}\right]$ probably formed with LAWABP1 glass because of its higher potassium content relative to the other ILAW glass formulations. The sodium borate phase probably forms in VHTs because B cannot be removed from the corrosion layer via mass transport into liquid water. This highly soluble phase would not be expected to form in a disposal system environment or in other types of laboratory experi-

\footnotetext{
${ }^{\mathbf{1}}$ Vapor-phase Hydration Test Procedure, GDL-VHT, Rev. 1, Pacific Northwest National Laboratory, Richland, WA (1999)
} 
ments with a free water phase present. Catapleite $\left[\mathrm{Na}_{2} \mathrm{ZrSi}_{3} \mathrm{O}_{9} \cdot 2 \mathrm{H}_{2} \mathrm{O}\right]$ is a mineral found in hydrothermally altered rocks, commonly in association with analcime and microcline [41].

Table 6. Alteration Products on VHT Samples as Determined by XRD

\begin{tabular}{cl} 
Glass Name & \multicolumn{1}{c}{ Phases } \\
\hline \hline HLP-31 & Analcime, $\mathrm{NaTiSi}_{2} \mathrm{O}_{6}$ \\
LAWABP1 & Analcime, $\mathrm{Na}_{6} \mathrm{Al}_{6} \mathrm{Si}_{10} \mathrm{O}_{32} 12 \mathrm{H}_{2} \mathrm{O}$, Phillipsite, \\
& $\mathrm{Na}_{7.55}(\mathrm{AlSiO})_{6}\left(\mathrm{~B}(\mathrm{OH})_{4}\right)_{1.685}\left(\mathrm{H}_{2} \mathrm{O}\right)_{1.97}$ \\
LAWA44 & Analcime, $\mathrm{NaTiSi}_{2} \mathrm{O}_{6}$, Catapleite \\
\hline
\end{tabular}

\subsubsection{Results for Other ILAW Glasses}

A matrix of 56 glasses was developed and tested with the aim to identify the impact of glass composition on long-term corrosion behavior and to develop an acceptable glass composition region [40]. Of the 56 glasses, 45 were designed to systematically vary the glass composition and 11 were selected because a large and growing database on their corrosion characteristics had accumulated. The glasses varied the concentrations of $\mathrm{SiO}_{2}, \mathrm{Al}_{2} \mathrm{O}_{3}, \mathrm{~B}_{2} \mathrm{O}_{3}, \mathrm{Fe}_{2} \mathrm{O}_{3}, \mathrm{TiO}_{2}, \mathrm{ZnO}$, $\mathrm{ZrO}_{2}, \mathrm{MgO}$, and $\mathrm{Na}_{2} \mathrm{O}$ across a wide composition range that covers, with high probability, the expected processing composition range of the ILAW glass producer. The test matrix was designed in collaboration with staff at the Catholic University of America (principal contractor responsible for ILAW waste form development) to ensure that the selected components and ranges were relevant to glasses that are under current development. For details on the specific glass compositions involved and complete test results, please see Shulz et al. [40]. We only provide a very brief overview of the results here. 
In Figure 33, we plot the logarithm of the measured $200^{\circ} \mathrm{C}$ VHT corrosion rate for all 56 of the HLP series glasses. Immediately obvious from the plot is that a large fraction of the test glasses have corrosion rates less than $10 \mathrm{~g} \mathrm{~m}^{-2} \mathrm{~d}^{-1}$. This result was quite unexpected because the aggressive, high-temperature conditions of the VHT were anticipated to produce high corrosion rates for a significantly larger fraction of the test glasses. Still, the VHT corrosion rate is a sensitive function of glass composition as the rates vary by over 4 orders of magnitude for the range of glass compositions tested. The corrosion rate results are essentially a direct measure of the stability of the glass with respect to a suite of alteration phases that form as a consequence of the glass/water reaction.

To more quantitatively analyze the results, the VHT corrosion rate data have been replotted in the form of a cumulative distribution function, as shown in Figure 34. The measured $200^{\circ} \mathrm{C}$ VHT corrosion rate for LAWABP1 glass is $4.8 \mathrm{~g} \mathrm{~m}^{-2} \mathrm{~d}^{-1}$ and the corresponding data point is highlighted in Figure 34. This glass is very near the midpoint of the distribution (half of the data set have higher

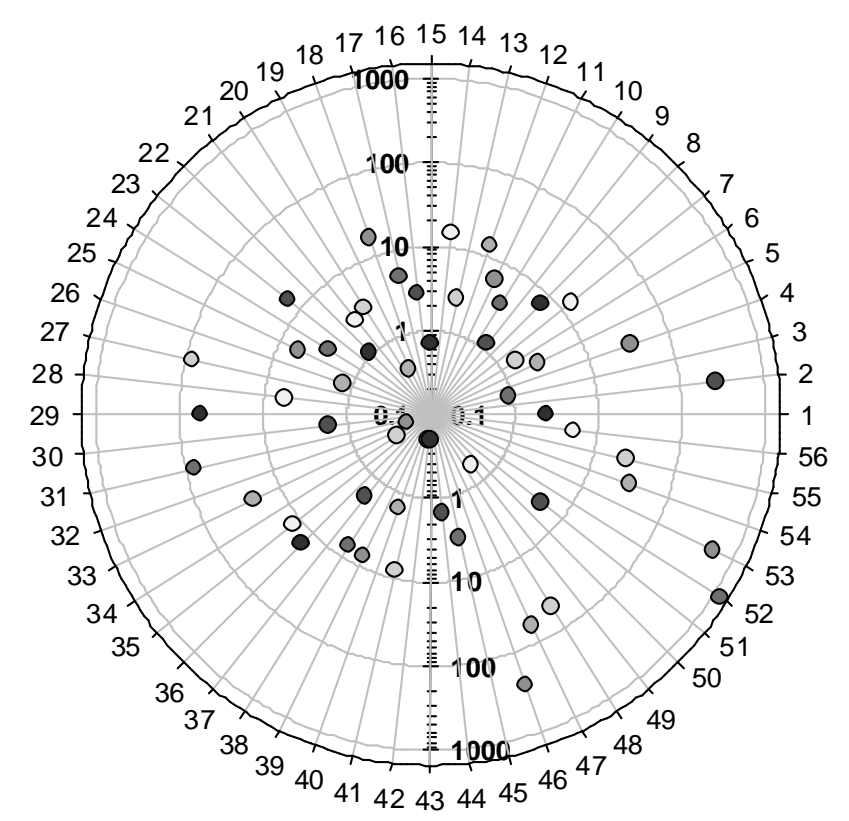

Figure 33. Radial Distribution Plot of $200^{\circ} \mathrm{C}$ VHT Corrosion Rates for HLP Series of ILAW Glasses. Radial coordinates are $\log _{10}$ corrosion rate, $\mathrm{g} \mathrm{m}^{-2} \mathrm{~d}^{-1}$.

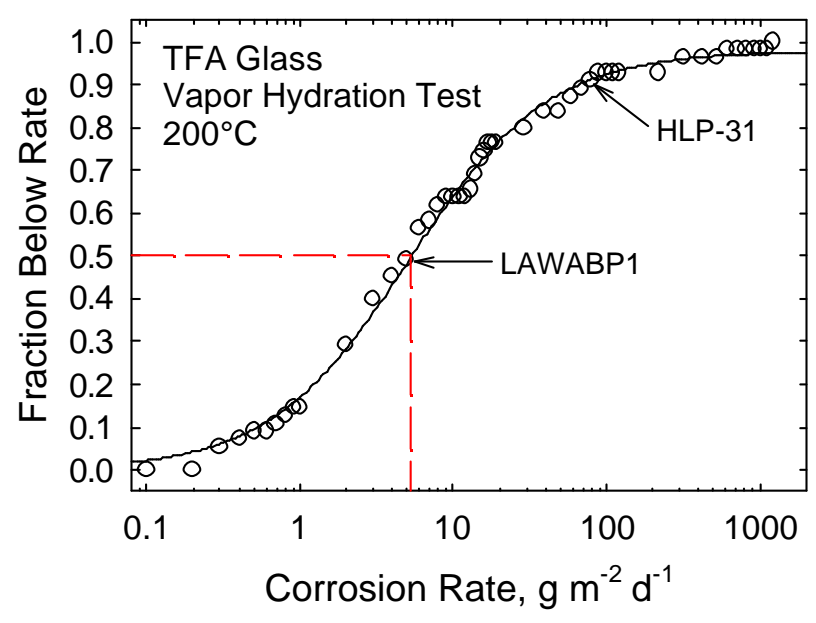

Figure 34. Cumulative Distribution Plot of $200^{\circ} \mathrm{C}$ VHT Corrosion Rates for HLP Series of ILAW Glasses. The data were fit to a 3parameter logistic function of the form $\mathrm{y}=$ $\mathrm{a} /\left[1+\left(\mathrm{x} / \mathrm{x}_{0}\right)^{\mathrm{b}}\right]$.

rate and half lower) of $5.1 \mathrm{~g} \mathrm{~m}^{-2} \mathrm{~d}^{-1}$. A full 80 percent of the tested glasses have $200^{\circ} \mathrm{C}$ VHT corrosion rates less than $30 \mathrm{~g} \mathrm{~m}^{-2} \mathrm{~d}^{-1}$. This is only about 8 times faster than the VHT rate for LAWABP1 glass. Consequently, it appears that a fairly large glass composition region will likely meet the required performance objectives for the ILAW disposal system. 


\subsection{THERMODYNAMIC DATA}

In addition to the secondary phases identified in PUF and VHT experiments with LAWABP1 and HLP-31 glasses (see Sections 4.1 and 4.2), an additional set of secondary phases was identified by modeling the dissolution of LAWABP1 glass in deionized water with the EQ3/6 code package [42] and the data0.com.R8 database [43]. We eliminated a large number of the phases listed in the EQ3/6 database from consideration by: 1) recognizing that formation of the phase is kinetically prohibited at the disposal system temperature of $15^{\circ} \mathrm{C}, 2$ ) noting that selection of the phase would violate the Gibbs phase rule, 3) comparing simulations with experiments and eliminating phases that generated solution compositions that were inconsistent with the experiments, or 4) considering phase stability over the range of chemical environments expected for the ILAW disposal system. The final set of phases was determined by modeling the solution chemistry observed in PCT experiments, as described below.

\subsubsection{PCT Description}

The Product Consistency Test (PCT) has been standardized as an ASTM standard procedure [44]. The ASTM standard includes two methods: PCT Method A was developed specifically for verifying process control of vitrified HLW forms and is conducted with specific values of test parameters; PCT Method B does not specify the values of test parameters. Because the PCT Method B encompasses commonly used variations of test parameters, we refer to all static dissolution tests with crushed glass generically as PCTs.

The PCTs were conducted by reacting an aliquot of crushed glass that had been sieved to isolate the 75 to $150 \mu \mathrm{m}(-100+200$ mesh $)$ size fraction with an aliquot of DIW in a sealed vessel at a temperature of $99^{\circ} \mathrm{C}$. All tests were run in Teflon PFA containers. The amount of glass and DIW was adjusted to achieve a glass surface area to solution volume ratio (S/V) of approxi-

mately $20,000 \mathrm{~m}^{-1}$. At the end of the test, an aliquot of the leachate was removed immediately, before the vessel was allowed to cool. This was done so that the sample accurately reflected the solution che mistry at the test temperature. Solution $\mathrm{pH}$ was also measured at temperature with a Ross $\mathrm{pH}$ electrode. The leachate aliquots were diluted 10:1, acidified with 1 vol\% Ultrex nitric acid, and then analyzed with ICP-OES and ICP-MS. A second aliquot was also removed attemperature and immediately filtered with a $1.8 \mathrm{~nm}$ average pore size Centricon filter. The filtered sample was also diluted 10:1, acidified with 1 vol\% Ultrex nitric acid, and then analyzed 
with ICP-OES and ICP-MS. The filtrations were performed to determine if colloids were present in the unfiltered leachate.

\subsubsection{PCT Results}

Results from PCT experiments with LAWABP1, HLP-31, and several other prototypic ILAW glasses are shown in Figure 35. Filtered leachates were not statistically different from the unfiltered samples, indicating little colloid formation during the tests. Several of the test glasses exhibited instability during the experiment where the corrosion

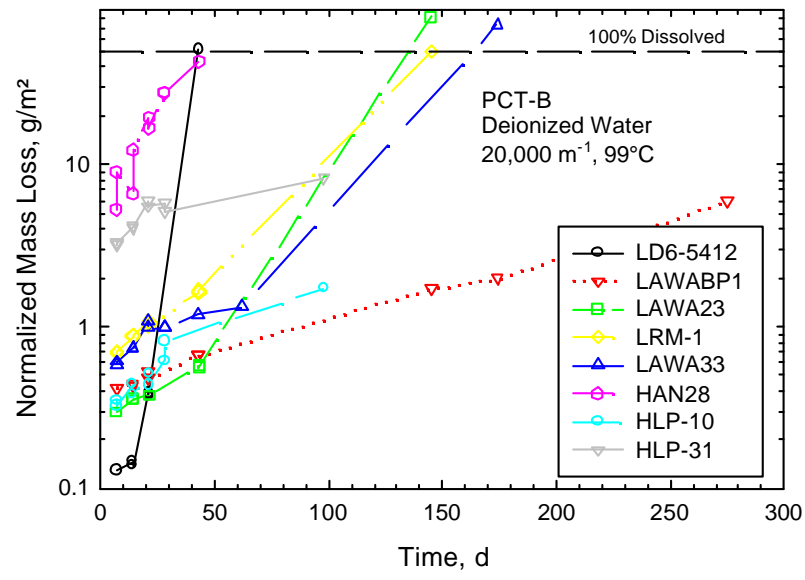

Figure 35. PCT Data for Selected ILAW Glasses rate suddenly accelerated between samplings. The acceleration was correlated with the formation of zeolites (analcime, herschelite, etc.). The corrosion rate accelerates sufficiently that the entire initial mass of glass (100\% dissolved line in Figure 35) is converted to alteration products. The reader should note that the normalized mass loss in Figure 35 was calculated based on the initial geometric surface area of the glass. At high values of mass loss, the diameter of the glass particles shrinks and eventually approaches zero whereupon the normalized mass loss becomes undefined.

\subsubsection{Modeling With EQ3/6}

Using the boron release data from the PCT experiments with LAWABP1 glass, a reaction progress value was calculated as a function of test duration. Reaction progress is simply the moles of glass dissolved in $1 \mathrm{~kg}$ of water. The results are shown in Figure 36. Also shown on the figure is the predicted elemental solution concentration from the EQ3/6 code. Agreement with the experimental data is extraordinarily good.

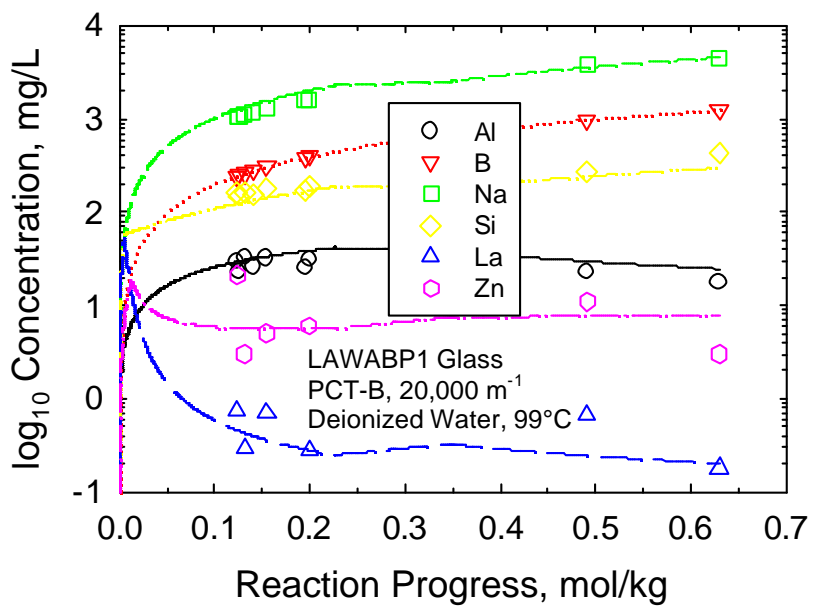

Figure 36. Comparison of PCT Solution Concentration Data with the Solution Composition Calculated with the EQ3/6 Code (lines) 
The predicted secondary phase paragenesis is provided in Figure 37. To adequately reproduce the PCT data, it was necessary to adjust the $\log \mathrm{K}$ upward for several of the phases [labeled as amorphous, e.g. $\left.\mathrm{La}(\mathrm{OH})_{3}(\mathrm{am})\right]$. This is a consequence of the fact that amorphous solids rather than their crystalline analogs often form in laboratory experiments with waste glasses. The amorphous solids are typically much more soluble and this is reflected in the equilibrium

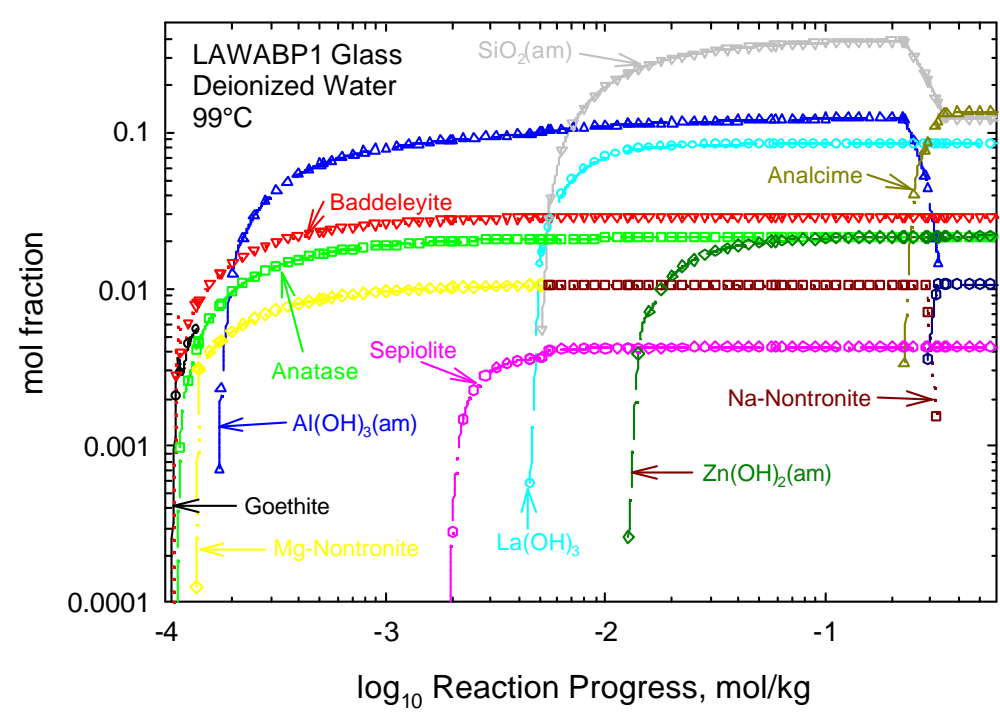

Figure 37. Predicted Paragenetic Sequence of Alteration Phases Formed During the Reaction of LAWABP1 Glass in Deionized Water. $\mathrm{PuO}_{2}$ and soddyite were also predicted to form. However, they are not shown because of the very small mol fractions associated with these phases.

constant. The $\log \mathrm{K}$ values assigned to each of the phases used in the simulations are provided in Table 7.

\subsubsection{Solubility Product for Herschelite}

Herschelite has been identified as a ubiquitous reaction product in PUF and VHT tests with a large number of BNFL, Inc. glass formulations, including LAWABP1. Because this phase is thought to be principally responsible for dissolution rate accelerations observed during testing, inclusion of this phase in the reaction network is mandatory. However, a solubility product for this phase is not included in the current thermodynamic database for EQ3/6 nor has a measured value been reported. Consequently, it was necessary to estimate a log $\mathrm{K}$ for herschelite.

The composition of herschelite forming from corrosion of a sample of LAWA33 glass was determined using EDS coupled to a SEM. From these data, the chemical formula for herschelite was calculated to be $\mathrm{Na}_{1.62} \mathrm{~K}_{0.50} \mathrm{Al}_{2.26} \mathrm{Si}_{4.00} \mathrm{O}_{12.45} \cdot 6 \mathrm{H}_{2} \mathrm{O}$. The temperature dependent solubility product was calculated using the approach outlined by Mattigod and Kittrick [45]. In this approach the temperature dependence of solubility of a mineral is expressed in the form:

$$
\log \mathrm{K}_{\mathrm{T}}=1 / 2.303 \mathrm{R}\left[\mathrm{A} \ln \mathrm{T}+\mathrm{BT}+\mathrm{C} / \mathrm{T}^{2}+\mathrm{D} / \mathrm{T}+\mathrm{E}\right]
$$


Table 7. Secondary Phase Reaction Network for LAWABP1 Glass. $\log \mathrm{K}$ is calculated at $15^{\circ} \mathrm{C}$ Phase

Aluminum Hydroxide

$\mathrm{Al}(\mathrm{OH})_{3}(\mathrm{am})$

Analcime

$\mathrm{Na}_{0.96} \mathrm{Al}_{0.96} \mathrm{Si}_{2.04} \mathrm{O}_{6} \cdot \mathrm{H}_{2} \mathrm{O}$

Anatase

$\mathrm{TiO}_{2}$

Baddeleyite

$\mathrm{ZrO}_{2}$

Catapleite

$\mathrm{Na}_{2} \mathrm{ZrSi}_{3} \mathrm{O}_{9} \cdot 2 \mathrm{H}_{2} \mathrm{O}$

Goethite

$\mathrm{Fe}(\mathrm{OH})_{3}$

Herschelite

$\mathrm{Na}_{1.62} \mathrm{~K}_{0.50} \mathrm{Al}_{2.26} \mathrm{Si}_{4.00} \mathrm{O}_{12.45} \cdot 6 \mathrm{H}_{2} \mathrm{O}$

Lanthanum Hydroxide

$\mathrm{La}(\mathrm{OH})_{3}(\mathrm{am})$

Nontronite-K

$\mathrm{K}_{0.33} \mathrm{Fe}_{2} \mathrm{Al}_{0.33} \mathrm{Si}_{3.67} \mathrm{O}_{11} \cdot \mathrm{H}_{2} \mathrm{O}$

Nontronite-Mg

$\mathrm{Mg}_{0.165} \mathrm{Fe}_{2} \mathrm{Al}_{0.33} \mathrm{Si}_{3.67} \mathrm{O}_{11} \cdot \mathrm{H}_{2} \mathrm{O}$

Nontronite- $\mathrm{Na}$

$\mathrm{Na}_{0.33} \mathrm{Fe}_{2} \mathrm{Al}_{0.33} \mathrm{Si}_{3.67} \mathrm{O}_{11} \cdot \mathrm{H}_{2} \mathrm{O}$

Phillipsite

$\mathrm{Na}_{0.5} \mathrm{~K}_{0.5} \mathrm{AlSi}_{3} \mathrm{O}_{8} \cdot \mathrm{H}_{2} \mathrm{O}$

Plutonium Oxide

$\mathrm{PuO}_{2}$

Sepiolite

$\mathrm{Mg}_{4} \mathrm{Si}_{6} \mathrm{O}_{15}(\mathrm{OH})_{2} \cdot 6 \mathrm{H}_{2} \mathrm{O}$

Sauconite

$\mathrm{Na}_{0.3} \mathrm{Zn}_{3}(\mathrm{Si}, \mathrm{Al})_{4} \mathrm{O}_{10}(\mathrm{OH})_{2} \cdot 4 \mathrm{H}_{2} \mathrm{O}$

Amorphous Silica

$\mathrm{SiO}_{2}(\mathrm{am})$

Soddyite

$\left(\mathrm{UO}_{2}\right)_{2} \mathrm{SiO}_{4} \cdot 2 \mathrm{H}_{2} \mathrm{O}$

Weeksite

$\mathrm{K}_{2}\left(\mathrm{UO}_{2}\right)_{2} \mathrm{Si}_{6} \mathrm{O}_{15} \cdot 4 \mathrm{H}_{2} \mathrm{O}$

Zinc Hydroxide

$\mathrm{Zn}(\mathrm{OH})_{2}$
$\mathrm{Al}(\mathrm{OH})_{3}(\mathrm{am})=\mathrm{AlO}_{2}^{-}+\mathrm{H}^{+}+\mathrm{H}_{2} \mathrm{O}$

Analcime $=0.96 \mathrm{AlO}_{2}^{-}+0.96 \mathrm{Na}^{+}+2.04 \mathrm{SiO}_{2}(\mathrm{aq})$

Anatase $+2 \mathrm{H}_{2} \mathrm{O}=\mathrm{Ti}(\mathrm{OH})_{4}(\mathrm{aq})$

$-6.64$

Baddeleyite $+2 \mathrm{H}_{2} \mathrm{O}=\mathrm{Zr}(\mathrm{OH})_{4}(\mathrm{aq})$

Catapleite $+2 \mathrm{H}^{+}=2 \mathrm{Na}^{+}+\mathrm{Zr}(\mathrm{OH})_{4}(\mathrm{aq})+3 \mathrm{SiO}_{2}(\mathrm{aq})+\mathrm{H}_{2} \mathrm{O}$

Unknown

Goethite $+\mathrm{H}_{2} \mathrm{O}=\mathrm{Fe}(\mathrm{OH})_{3}(\mathrm{aq})$

Herschelite $=1.62 \mathrm{Na}^{+}(\mathrm{aq})+0.50 \mathrm{~K}^{+}(\mathrm{aq})+2.26 \mathrm{AlO}_{2}{ }^{-}+4 \mathrm{SiO}_{2}(\mathrm{aq})+0.14 \mathrm{H}^{+}+5.93 \mathrm{H}_{2} \mathrm{O}$

$-40.94$

$\mathrm{La}(\mathrm{OH})_{3}(\mathrm{am})+3 \mathrm{H}^{+}=3 \mathrm{H}_{2} \mathrm{O}+\mathrm{La}^{3+}$

Nontronite- $\mathrm{K}+2 \mathrm{H}_{2} \mathrm{O}=0.330 \mathrm{AlO}_{2}^{-}+2 \mathrm{Fe}(\mathrm{OH})_{3}(\mathrm{aq})+0.330 \mathrm{~K}^{+}+3.67 \mathrm{SiO}_{2}(\mathrm{aq})$

Nontronite- $\mathrm{Mg}+2 \mathrm{H}_{2} \mathrm{O}=0.330 \mathrm{AlO}_{2}^{-}+2 \mathrm{Fe}(\mathrm{OH})_{3}(\mathrm{aq})+0.165 \mathrm{Mg}^{2+}+3.67 \mathrm{SiO}_{2}(\mathrm{aq})$

Nontronite- $\mathrm{Na}+2 \mathrm{H}_{2} \mathrm{O}=0.330 \mathrm{AlO}_{2}^{-}+2 \mathrm{Fe}(\mathrm{OH})_{3}(\mathrm{aq})+0.330 \mathrm{Na}^{+}+3.67 \mathrm{SiO}_{2}(\mathrm{aq})$

Phillipsite $=0.5 \mathrm{Na}^{+}+0.5 \mathrm{~K}^{+}+\mathrm{AlO}_{2}^{-}+3 \mathrm{SiO}_{2}(\mathrm{aq})+\mathrm{H}_{2} \mathrm{O}$

$\mathrm{PuO}_{2}+\mathrm{H}^{+}+0.25 \mathrm{O}_{2}(\mathrm{~g})=\mathrm{PuO}_{2}^{+}+0.5 \mathrm{H}_{2} \mathrm{O}$

Sepiolite $+8 \mathrm{H}^{+}=4 \mathrm{Mg}^{2+}+6 \mathrm{SiO}_{2}(\mathrm{aq})+11 \mathrm{H}_{2} \mathrm{O}$

Sauconite $+5 \mathrm{H}^{+}=0.3 \mathrm{Na}^{+}+3 \mathrm{Zn}^{2+}+2.95 \mathrm{SiO}_{2}(\mathrm{aq})+1.3 \mathrm{AlO}_{2}^{-}+7.5 \mathrm{H}_{2} \mathrm{O}$

Unknown

$\mathrm{SiO}_{2}(\mathrm{am})=\mathrm{SiO}_{2}(\mathrm{aq})$

Soddyite $=2 \mathrm{UO}_{2}^{2+}+\mathrm{SiO}_{2}(\mathrm{aq})$

Weeksite $+6 \mathrm{H}^{+}=2 \mathrm{~K}^{+}+2 \mathrm{UO}_{2}^{2+}+6 \mathrm{SiO}_{2}(\mathrm{aq})+7 \mathrm{H}_{2} \mathrm{O}$

$\mathrm{Zn}(\mathrm{OH})_{2}(\mathrm{am})+2 \mathrm{H}^{+}=2 \mathrm{H}_{2} \mathrm{O}+\mathrm{Zn}^{2+}$

where $\mathrm{K}_{\mathrm{T}}$ is the solubility product at temperature $\mathrm{T}\left({ }^{\circ} \mathrm{K}\right), \mathrm{R}$ is the gas constant, $\mathrm{A}=\Delta \mathrm{a}, \mathrm{B}=\Delta \mathrm{b} / 2$, $\mathrm{C}=\Delta \mathrm{c} / 2, \mathrm{D}=\left[\Delta \mathrm{a} \mathrm{T}_{\mathrm{r}}+(\Delta \mathrm{b} / 2) \mathrm{T}_{\mathrm{r}}^{2}-\Delta \mathrm{c} / \mathrm{T}_{\mathrm{r}}-\Delta \mathrm{S}^{0} \mathrm{~T}_{\mathrm{r}}+\mathrm{RT} \ln \mathrm{K}_{\mathrm{Tr}}\right]$, and $\mathrm{E}=\left[-\Delta \mathrm{a}-\Delta \mathrm{a} \ln \mathrm{T}_{\mathrm{r}}-\Delta \mathrm{b} \mathrm{T}_{\mathrm{r}}\right.$ $\left.+\left(\Delta \mathrm{c} / 2 \mathrm{~T}_{\mathrm{r}}^{2}\right)+\Delta \mathrm{S}^{0}\right]$, and $\Delta \mathrm{a}, \Delta \mathrm{b}$, and $\Delta \mathrm{c}$ are the heat capacity of reaction coefficients from MeierKelly equation 


$$
\Delta \mathrm{C}_{\mathrm{p}}=\Delta \mathrm{a}+\Delta \mathrm{b} \mathrm{T}+\Delta \mathrm{c} / \mathrm{T}^{2}
$$

where $\Delta S^{0}=$ entropy of reaction

$\mathrm{K}_{\mathrm{Tr}}=$ solubility product at a reference temperature $\left(298.15{ }^{0} \mathrm{~K}\right)$.

The dissolution/precipitation reaction of herschelite is expressed in the form:

$\mathrm{Na}_{1.62} \mathrm{~K}_{0.50} \mathrm{Al}_{2.26} \mathrm{Si}_{4.00} \mathrm{O}_{12.45} 6 \mathrm{H}_{2} \mathrm{O}$ (solid) $+8.9 \mathrm{H}^{+}(\mathrm{aq})=$

$1.62 \mathrm{Na}^{+}(\mathrm{aq})+0.50 \mathrm{~K}^{+}(\mathrm{aq})+2.26 \mathrm{Al}^{3+}(\mathrm{aq})+4 \mathrm{Si}(\mathrm{OH})_{4}{ }^{0}(\mathrm{aq})+2.45 \mathrm{H}_{2} \mathrm{O}$

The solubility product for this reaction is expressed as:

$\log \mathrm{K}_{\mathrm{T}}=1.62 \log \mathrm{Na}^{+}+0.50 \log \mathrm{K}^{+}+2.26 \log \mathrm{Al}^{3+}+4 \operatorname{logSi}(\mathrm{OH})_{4}{ }^{0}+8 \log \mathrm{H}^{+}=$ $1 / 2.303 \mathrm{R}\left[\mathrm{A} \ln \mathrm{T}+\mathrm{BT}+\mathrm{C} / \mathrm{T}^{2}+\mathrm{D} / \mathrm{T}+\mathrm{E}\right]$

The sources of thermochemical data used in the equilibrium constant calculations are listed in Table 8. Using Kirchhoff's law, the Gibbs free energy of reaction was calculated as a function of temperature. The solubility product was then calculated using the expression

$$
\ln \mathrm{K}(\mathrm{T})=-\Delta \mathrm{G}^{\mathrm{O}} / 2.479
$$

where $\Delta G^{o}$ is the free energy of reaction. The resulting empirical formula for computing $K(T)$ is

$$
\log \mathrm{K}_{\mathrm{T}}=-11.5438 \ln \mathrm{T}+0.071779 \mathrm{~T}+8.8225 \times 10^{4} / \mathrm{T}^{2}+1.1881 \times 10^{4} / \mathrm{T}+15.654 \text {. }
$$

The solubility product for herschelite was calculated with Equation (15) at $10^{\circ}$ temperature intervals starting from $15^{\circ} \mathrm{C}$ to $95^{\circ} \mathrm{C}$. The computations showed that the solubility product of herschelite changes by about six orders of magnitude between 15 and $95^{\circ} \mathrm{C}$, indicating significantly higher solubility at higher temperature as compared to its solubility at ambient temperature. The $\log \mathrm{K}$ at $15^{\circ} \mathrm{C}$ is 13.26 given the reaction written as Equation (12). In Table 7, the dissolution-precipitation reaction for herschelite is given with $\mathrm{AlO}_{2}{ }^{-}$as the aluminate species instead of $\mathrm{Al}^{3+}$ as in Equation (12). Consequently, the $\log \mathrm{K}$ in Table 7 reflects a correction for the reaction:

$$
\mathrm{Al}^{3+}+2 \mathrm{H}_{2} \mathrm{O}=\mathrm{AlO}_{2}^{-}+4 \mathrm{H}^{+} \quad \log _{10} \mathrm{~K}\left(15^{\circ} \mathrm{C}\right)=-23.98
$$


Table 8. Thermochemical Data used in the Calculations

\begin{tabular}{|c|c|c|c|c|c|}
\hline \multirow[t]{2}{*}{ Species } & $\begin{array}{c}\Delta \mathrm{G}_{\mathrm{f}}^{0} \\
(\mathrm{~kJ} / \mathrm{mol})\end{array}$ & $\begin{array}{l}\mathrm{S}_{298.15}^{0} \\
(\mathrm{~J} / \mathrm{mol} \mathrm{deg})\end{array}$ & \multicolumn{3}{|c|}{$\begin{array}{c}\mathrm{C}_{\mathrm{p}}=\mathrm{a}+\mathrm{bT}+\mathrm{c} / \mathrm{T}^{2} \\
(\mathrm{~J} / \mathrm{mol} \mathrm{deg})\end{array}$} \\
\hline & & & $\mathrm{a}$ & $\mathrm{b} \times 10^{3}$ & $\mathrm{c} \times 10^{-5}$ \\
\hline $\begin{array}{l}\mathrm{Na}_{1.62} \mathrm{~K}_{0.50} \mathrm{Al}_{2.26} \mathrm{Si}_{4.00} \mathrm{O}_{12.45} 6 \mathrm{H}_{2} \mathrm{O} \\
\text { (herschelite) }\end{array}$ & -7405.40 & 691.41 & 342.68 & 841.05 & 13.10 \\
\hline $\mathrm{H}_{2} \mathrm{O}$ (liq) & -237.14 & 69.91 & 49.66 & 54.31 & 8.44 \\
\hline $\mathrm{Na}^{+}(\mathrm{aq})$ & -261.90 & 59.00 & 0 & 155.64 & 0 \\
\hline $\mathrm{K}^{+}(\mathrm{aq})$ & -282.49 & 102.50 & 0 & 72.80 & 0 \\
\hline $\mathrm{Al}^{3+}(\mathrm{aq})$ & -485.00 & -321.70 & 0 & 128.03 & 0 \\
\hline $\mathrm{Si}(\mathrm{OH})_{4}{ }^{0}(\mathrm{aq})$ & -1308.00 & 180.00 & 0 & 719.65 & 0 \\
\hline
\end{tabular}

$\Delta \mathrm{G}_{\mathrm{f}}^{0}$ values: herschelite estimated by the method of Mattigod and McGrail [46], for all other species from Robie et al. [47].

$\mathrm{S}_{298.15}^{0}$ values: herschelite estimated by the method of Robinson and Haas [48], for all other species from Wagman et al. [49].

$\mathrm{C}_{\mathrm{p}}$ coefficients: herschelite estimated by the method of Robinson and Haas [48] and fit to MK equation, $\mathrm{H}_{2} \mathrm{O}$ from Mattigod and Kittrick [45], for all other aqueous species from Naumov [50]. 


\subsection{CONCLUSION}

In this data package, a large body of data is presented on the corrosion behavior of LAWABP1, a prototypic glass for low-activity waste. Four test methods, SPFT, PCT, VHT, and PUF were used in combination to examine the corrosion behavior of the glass over a wide range of conditions. Results from these experiments were used to derive the parameters necessary to conduct long-term PA calculations with the STORM reactive transport computer code.

In addition to the data on LAWABP1 glass, experiments were also conducted with HLP-31 glass, which has a $15 \%$ greater waste loading than LAWABP1 glass. This glass was selected for a waste loading sensitivity case calculation in the 2001 ILAW PA. In room temperature SPFT experiments, this glass showed a fixed rate of dissolution that was independent of solution composition, i.e. the rate did not diminish as the silicic acid concentration in the input solution was increased. Moreover, the rate was 10 to $15 \mathrm{X}$ faster than has been observed for numerous other silicate-based waste glasses. Phase separation into borate rich regions, which are susceptible to hydrolysis reactions, may explain its unusual corrosion behavior.

Vapor phase hydration experiments were also conducted with a statistically designed matrix of 56 glasses that spans the anticipated processing region. At $200^{\circ} \mathrm{C}$, VHT corrosion rates were a strong function of composition with a maximum rate of $1219 \mathrm{~g} \mathrm{~m}^{-2} \mathrm{~d}^{-1}$ and minimum rate of $0.1 \mathrm{~g} \mathrm{~m}^{-2} \mathrm{~d}^{-1}$, a four order of magnitude spread. However, the distribution of rates was logarithmic such that $80 \%$ of the test glasses had VHT corrosion rates within a factor 8 of the corrosion rate for LAWABP1 glass $\left(4.8 \mathrm{~g} \mathrm{~m}^{-2} \mathrm{~d}^{-1}\right)$. Assuming that the VHT corrosion rates approximate actual disposal system behavior, it appears that a large glass composition region is available to produce ILAW glasses that will meet performance objectives for the ILAW disposal system. 
Table 9. Summary of Best Estimate Rate Law Parameters for LAWABP1 and HLP-31 Glasses at $15^{\circ} \mathrm{C}$

\begin{tabular}{|c|c|c|c|c|}
\hline Parameter & Meaning & LAWABP1 & HLP-31 & Comments \\
\hline$\vec{k}$ & $\begin{array}{l}\text { forward rate constant } \\
\left(\mathrm{g} \mathrm{m}^{-2} \mathrm{~d}^{-1}\right)\end{array}$ & $3.4 \times 10^{6}$ & $1.0 \times 10^{7}$ & $\begin{array}{l}\text { HLP-31 based on } 26^{\circ} \mathrm{C} \\
\text { data only }\end{array}$ \\
\hline$K_{g}$ & $\begin{array}{l}\text { apparent equilibrium } \\
\text { constant for glass } \\
\text { based on activity } \\
\text { product } \mathrm{a}\left[\mathrm{SiO}_{2}(\mathrm{aq})\right]\end{array}$ & $4.9 \times 10^{-4}$ & ND & $\begin{array}{l}\text { Not Defined. The HLP- } \\
31 \text { glass dissolution rate } \\
\text { did not change as func- } \\
\text { tion of a }\left[\mathrm{SiO}_{2}(\mathrm{aq})\right]\end{array}$ \\
\hline$\eta$ & $\begin{array}{l}\text { pH power law coef- } \\
\text { ficent }\end{array}$ & 0.35 & 0.35 & $\begin{array}{l}\text { HLP-31 value assumed } \\
\text { same as LAWABP1 }\end{array}$ \\
\hline$E_{a}$ & $\begin{array}{l}\text { activation energy of } \\
\text { glass dissolution re- } \\
\text { action }(\mathrm{kJ} / \mathrm{mol})\end{array}$ & 68 & 68 & $\begin{array}{l}\text { HLP- } 31 \text { value assumed } \\
\text { same as LAWABP1 }\end{array}$ \\
\hline$\sigma$ & Temkin coefficient & 1 & 1 & Assigned constant \\
\hline$r_{x}$ & $\begin{array}{l}\text { Na ion-exchange rate } \\
\left(\mathrm{mol} \mathrm{m}^{-2} \mathrm{~s}^{-1}\right)\end{array}$ & $3.4 \times 10^{-11}$ & 0 & $\begin{array}{l}\text { No detectable ion ex- } \\
\text { change rate for HLP- } 31\end{array}$ \\
\hline
\end{tabular}




\subsection{REFERENCES}

1. McGrail, B. P., W. L. Ebert, D. H. Bacon, and K. P. Saripalli. 2000. A Strategy to Conduct an Analysis of the Long-Term Performance of Low-Activity Waste Glass in a Shallow Subsurface Disposal System at Hanford. PNNL-11834 Rev. 1, Pacific Northwest National Laboratory, Richland, Washington.

2. McGrail, B. P., and D. H. Bacon. 1998. Selection of a Computer Code for Hanford LowLevel Waste Engineered-System Performance Assessment. PNNL-10830, Rev. 1, Pacific Northwest National Laboratory, Richland, Washington.

3. Meyer, P. D., and R. J. Serne. 1999. Near-Field Hydrology Data Package for the Immobilized Low-Activity Waste 2001 Performance Assessment. PNNL-13035, Pacific Northwest National Laboratory, Richland, Washington.

4. Ebert, W. L., D. M. Strachan, and S. F. Wolf. 1998. Formulation of a Candidate Glass for Use as an Acceptance Test Standard Material. ANL-98/10, Argonne National Laboratory, Argonne, Illinois.

5. Schulz, R. L., T. H. Lorier, D. K. Peeler, K. G. Brown, I. A. Reamer, J. D. Vienna, A. Jiricka, B. M. Jorgensen, and D. E. Smith. 2000. Hanford Immobilized LAW Product Acceptance: Tanks Focus Area Testing Data Package II. PNNL-13344, Pacific Northwest National Laboratory, Washington.

6. Aagard, P. and Helgeson, H.C. 1982. "Thermodynamic and Kinetic Constraints on Reaction Rates Among Minerals and Aqueous Solutions. I. Theoretical Considerations." Am. J. Sci., 282:237-285.

7. Lasaga, A. C. 1995. "Fundamental Approaches in Describing Mineral Dissolution and Precipitation Rates." In Chemical Weathering Rates of Silicate Minerals, Reviews in Mineralogy, Vol. 31, Ed. A. F. White and S. L. Brantley, Mineralogical Society of America, Washington, D. C.

8. McGrail, B. P., W. L. Ebert, A. J. Bakel, and D. K. Peeler. 1997. "Measurement of Kinetic Rate Law Parameters on a Na-Ca-Al Borosilicate Glass for Low-Activity Waste." J. Nuc. Mat. 249:175-189.

9. Abraitis, P. K., B. P. McGrail, D. P. Trivedi, F. R. Livens, and D. J. Vaughan. 2000. “Single-pass Flow-through Experiments on a Simulated Waste Glass in Alkaline Media at $40^{\circ} \mathrm{C}$. Part 1: Experiments Conducted at Variable Solution Flow Rate to Glass Surface Area Ratio." J. Nuc. Mat. 280(2):196-205.

10. Abraitis, P. K., B. P. McGrail, D. P. Trivedi, F. R. Livens, and D. J. Vaughan. 2000. "Single-pass Flow-through Experiments on a Simulated Waste Glass in Alkaline Media at $40{ }^{\circ} \mathrm{C}$. Part 2: Experiments Conducted With Buffer Solutions Containing Controlled Quantities of Si and Al." J. Nuc. Mat. 280(2):206-215.

11. McGrail, B. P., J. P. Icenhower, P. F. Martin, D. R. Rector, H. T. Schaef, E. A. Rodriguez, and J. L. Steele. 2000. Low-Activity Waste Glass Studies: FY2000 Summary Report. PNNL-13381, Pacific Northwest National Laboratory, Richland, Washington. 
12. Brunauer, S., Emmett. P. H., and Teller, E. 1938. "Adsorption of Gases in Multimolecular Layers." J. Phys. Chem. 60:309-319.

13. Dove, P. M., and Crerar, D. A. 1990. "Kinetics of Quartz Dissolution in Electrolyte Solutions Using a Hydrothermal Mixed Flow Reactor." Geochim. Cosmochim. Acta 54:955-969.

14. Drever, J. I. 1994. "The Effect of Land Plants on Weathering Rates of Silicate Minerals." Geochim. Cosmochim. Acta 58(10):2325-2332.

15. Dove, P. M. 1994. "The Dissolution Kinetics of Quartz in Sodium Chloride Solutions at 25' to $300^{\circ} \mathrm{C}$." Am. J. Sci. 294:665-712.

16. Icenhower, J. P. and Dove, P. M. 2000. "The Dissolution Kinetics of Amorphous Silica Into Sodium Chloride Solutions: Effects of Temperature and Ionic Strength." Geochim. Cosmochim. Acta, in press.

17. Renders, P. J. N., C. H. Gammons, and H. L. Barnes. 1995. "Precipitation and Dissolution Rate Constants for Cristobalite From 150 to $300^{\circ}$ C." Geochim. Cosmochim. Acta 59(1):7785.

18. Gin, S. 1996. "Control of R7T7 Nuclear Glass Alteration Kinetics Under Saturation Conditions.” Mat. Res. Soc. Symp. Proc. 412:189-196.

19. McGrail, B. P., D. H. Bacon, J. P. Icenhower, F. M. Mann, R. J. Puigh, H. T. Schaef, and S. V. Mattigod. 2000. "Near-Field Performance Assessment for a Low-Activity Waste Glass Disposal System: Laboratory Testing to Modeling Results.” J. Nuc. Mat. (in press).

20. Bourcier, W. L. 1989. Geochemical Modeling of Radioactive Waste Glass Dissolution Using EQ3/6: Preliminary Results and Data Needs. UCID-21869, Lawrence Livermore National Laboratory, Livermore, California.

21. Advocat, T., J. L. Crovisier, B. Fritz, and E. Vernaz. 1990. "Thermokinetic Model of Borosilicate Glass Dissolution.” Mat. Res. Soc. Symp. Proc. 176:241-248.

22. Grambow, B. E. 1985. "A General Rate Equation for Nuclear Waste Glass Corrosion." Mat. Res. Soc. Symp. Proc. 44:15-27.

23. Bourcier, W. L., D. W. Peiffer, K. G. Knauss, K. D. McKeegan, and D. K. Smith. 1990. A Kinetic Model for Borosilicate Glass Dissolution Based on the Dissolution Affinity of a Surface Alteration Layer." Mat. Res. Soc. Symp. Proc. 176:209-216.

24. Jégou, C., S. Gin, and F. Larché. 2000. “Alteration Kinetics of a Simplified Nuclear Glass in an Aqueous Medium: Effects of Solution Chemistry and of Protective Gel Properties on Diminishing the Alteration Rate." J. Nuc. Mat. 280:216-229.

25. McGrail, B. P., J. P. Icenhower, D. K Shuh, P. Liu, J. G. Darab, D. R. Baer, S. Thevuthasen, V. Shutthanandan, M. H. Engelhard, C. H. Booth, and P. Nachimuthu. 2000. "The Structure of $\mathrm{Na}_{2} \mathrm{O}-\mathrm{Al}_{2} \mathrm{O}_{3}-\mathrm{SiO}_{2}$ Glass: Impact on Sodium Ion Exchange in $\mathrm{H}_{2} \mathrm{O}$ and $\mathrm{D}_{2} \mathrm{O}$." J. NonCryst. Solids (submitted).

26. Pederson, L.R. 1987. "Comparison of Sodium Leaching Rates From a $\mathrm{Na}_{2} \mathrm{O} \cdot 3 \mathrm{SiO}_{2} \mathrm{Glass}$ in $\mathrm{H}_{2} \mathrm{O}$ and $\mathrm{D}_{2} \mathrm{O}$." Phys. Chem. Glass 28(1):17-21. 
27. Bunker, B. C. 1987. "Waste Glass Leaching: Chemistry and Kinetics." Mat. Res. Soc. Symp. Proc. 84:493-507.

28. Schnitzer, M. 1989. "Binding of Humic Substances by Soil Mineral Colloids." Interactions of Soil Minerals with Natural Organics and Microbes, SSSA Special Publication No. 17, P.M. Huang and M. Schnitzer, Eds., Madison, Wisconsin, pp. 77-101.

29. Bennett, P. C., M. E. Melcer, D. I. Siegel, J. P. Hassett. 1988. "The Dissolution of Quartz in Dilute Aqueous Solutions of Organic Acids at $25^{\circ} \mathrm{C}$." Geochim. Cosmochim. Acta 52:1521-1530.

30. Gin, S., N. Godon, J. P. Mestre, and E. Y. Vernaz. 1994. "Experimental Investigation of Aqueous Corrosion of R7T7 Nuclear Glass at $90^{\circ} \mathrm{C}$ in the Presence of Organic Species." Appl. Geochem. 9:255-269.

31. Toste, A. P. 1999. "A Case Study on the Role of Naturally-Occurring Organics in Subsurface Radionuclide Migration: The N Reactor's Crib-Trench System.” NUCEF'98 Symposium Working Group, Japan Atomic Energy Research Institute, Conf. 99-004, pp. 370-377.

32. Malcolm, R. L., and P. MacCarthy. 1986. "Limitations in the Use of Commercial Humic Acids in Water and Soil Research.” Environ. Sci. Tech. 20:904-911.

33. Hayes, M. H. B., and R. S. Swift. 1990. "Genesis, Isolation, Composition and Structures of Soil Humic Substances." Soil Colloids and Their Associations in Aggregates, M. F. de Boodt, M. H. B. Hayes, and A. Herbillon Eds., Plenum Press, New York, pp 245-305.

34. Fleet, M. E., and S. Muthupari. 1999. "Coordination of Boron in Alkali Borosilicate Glasses Using XANES.” J. Non-Cryst. Solids 255:233-241.

35. McGrail, B. P., C. W. Lindenmeier, P. F. C. Martin, and G. W. Gee. 1996. "The Pressurized Unsaturated Flow (PUF) Test: A New Method for Engineered-Barrier Materials Evaluation." Trans. Am. Ceram. Soc. 72:317-329.

36. McGrail, B. P., P. F. Martin, and C. W. Lindenmeier. 1997. “Accelerated Testing of Waste Forms Using a Novel Pressurized Unsaturated Flow (PUF) Method.” Mat. Res. Soc. Symp. Proc. 465:253-260.

37. Wierenga, P. J., Young, M. H., Gee, G. W., Hills, R. G., Kincaid, C. T., Nicholson, T. J., and Cady, R. E. 1993. Soil Characterization Methods for Unsaturated Low-Level Waste Sites. PNL-8480, Pacific Northwest Laboratory, Richland, Washington.

38. ASTM. 1995. Standard Test Methods for Determining Chemical Durability of Nuclear Waste Glasses: The Product Consistency Test (PCT). ASTM Standard C1285-94.

39. McGrail, B. P., P. F. Martin, C. W. Lindenmeier, H. T. Schaef. 1998. Corrosion Testing of Low-Activity Waste Glasses: Fiscal Year 1998 Summary Report. PNNL-12014, Pacific Northwest National Laboratory, Richland, Washington.

40. Schulz, R. L., T. H. Lorier, D. K. Peeler, K. G. Brown, I. A. Reamer, J. D. Vienna, A. Jiricka, B. M. Jorgensen, and D. E. Smith. 2000. Hanford Immobilized LAW Product Acceptance: Tanks Focus Area Testing Data Package II. PNNL-13344, Pacific Northwest National Laboratory, Richland, Washington. 
41. Iliushin, G. D., A. A. Voronkov, V. V. Iliukhin, N. N. Nevskii, and N. V. Belov. 1981. "Crystal-Structure of Native Monoclinic Catapleite, $\mathrm{Na}_{2} \mathrm{ZrSi}_{3} \mathrm{O}_{9} \cdot 2 \mathrm{H}_{2} \mathrm{O}$." Doklady Akademii Nauk SSSR 260(3):623-627.

42. Wolery, T. J., and S. A. Daveler. 1992. EQ6, A Computer Program for Reaction Path Modeling of Aqueous Geochemical Systems: Theoretical Manual, User's Guide and Related Documentation. UCRL-MA-110662 PT IV, Lawrence Livermore Laboratory, Livermore, California.

43. Daveler, S. A., and T. J. Wolery. 1992. EQPT, A Data File Preprocessor for the EQ3/6 Software Package: User's Guide and Related Documentation (Version 7.0). UCRL-MA110662 PT II, Lawrence Livermore National Laboratory, Livermore, California.

44. American Society for Testing and Materials (ASTM). 1994. Standard Test Methods for Determining Chemical Durability of Nuclear Waste Glasses: The Product Consistency Test $(P C T)$. ASTM C1285, Philadelphia, Pennsylvania.

45. Mattigod, S. V., and J. A. Kittrick. 1980. "Temperature and Water Activity as Variables in Soil Mineral Activity Diagrams." Soil Sci. Soc. Am. J. 44:149-154.

46. Mattigod, S. V., and B. P. McGrail. 1999. "Estimating the Free Energy of Formation of Zeolites Using the Polymer Model." Micro. Meso. Materials 27:41-47.

47. Robie, R. A., B. S. Hemingway, and J. R. Fisher. 1978. Thermodynamic Properties of Minerals and Related Substances at $298.15^{\circ} \mathrm{K}$ and 1 Bar Pressure and at Higher Temperatures. USGS Bulletin 1452, U.S. Geological Survey, Washington D.C.

48. Robinson, G. P., and J. L. Haas. 1983. "Heat Capacity, Relative Enthalpy, and Calorimetric Entropy of Silicate Minerals: An Empirical Method of Prediction.” Am. Mineralogist 68:541-543.

49. Wagman, D. D., W. H. Evans, V. B. Parker, R. H. Schumm, I. Halow, S. M. Bailey, L. L. Churney, R. L. Nuttal. 1982. J. Phys. Chem. Ref. Data 11, Suppl. 2.

50. Naumov, G. B., B. N. Ryzenko, and I. L. Khodakovsky. 1974. Handbook of Thermodynamic Data. NTIS PB-226 722, National Technical Information Service, Washington D.C. 


\section{$\underline{\text { APPENDIX }}$}

Table A.1. Experimental Parameters, Effluent Chemical Analysis, and Dissolution Rate Values For SPFT Experiments With LAWABP1 Glasses

\begin{tabular}{|c|c|c|c|c|c|c|c|c|c|c|c|c|}
\hline Expt. \# & $\begin{array}{l}\text { WABP1 Glass } \\
\text { Description } \\
\end{array}$ & $\begin{array}{c}\text { Temp } \\
\left({ }^{\circ} \mathrm{C}\right) \\
\end{array}$ & $\mathrm{pH}$ & $\begin{array}{c}\text { mass } \\
(\mathrm{g}) \\
\end{array}$ & $\begin{array}{c}\text { average } \\
\text { flow rate } \\
\text { (mL/d) }\end{array}$ & $\begin{array}{c}\text { average } \\
\text { B conc. } \\
\text { (ppb) } \\
\end{array}$ & $\begin{array}{c}\text { average } \\
\text { Na conc. } \\
\text { (ppb) } \\
\end{array}$ & $\begin{array}{c}\text { average } \\
\text { Al conc. } \\
\text { (ppb) } \\
\end{array}$ & $\begin{array}{c}\text { average } \\
\text { Si conc. } \\
\text { (ppb) } \\
\end{array}$ & $\begin{array}{c}\text { average } \\
\text { B rate } \\
\left(\mathrm{g} \mathrm{m}^{-2} \mathrm{~d}^{-1}\right) \\
\end{array}$ & $\begin{array}{c}2 \sigma_{r} \\
\text { uncertainty } \\
\left(\mathrm{g} \mathrm{m}^{-2} \mathrm{~d}^{-1}\right) \\
\end{array}$ & Notes \\
\hline 1 & forward rate & 90 & 9.03 & 0.50 & 88 & 678 & 4,204 & 1,138 & 4,186 & $1.95 \mathrm{E}-01$ & $6.13 \mathrm{E}-02$ & 1 \\
\hline 2 & & 90 & 9.03 & 0.51 & 81 & 623 & 4,281 & 1,318 & 4,035 & $1.91 \mathrm{E}-01$ & 5.84E-02 & 1 \\
\hline 40 & & 90 & 9.00 & 0.50 & 95 & 502 & 2,325 & 744 & 3,294 & $1.58 \mathrm{E}-01$ & 2.69E-02 & 1 \\
\hline 41 & & 90 & 9.00 & 0.50 & 95 & 439 & 2,088 & 601 & 2,938 & $1.41 \mathrm{E}-01$ & 2.38E-02 & 1 \\
\hline 42 & & 90 & 9.18 & 0.50 & 30 & 290 & 1,452 & 456 & 2,304 & 2.24E-01 & 3.81E-02 & 2 \\
\hline 43 & & 90 & 9.18 & 0.50 & 30 & 308 & 1,866 & 576 & 2,468 & $2.45 \mathrm{E}-01$ & 4.14E-02 & 2 \\
\hline 3 & & 70 & 9.11 & 0.53 & 92 & 223 & 1,350 & 413 & 3,144 & 6.46E-02 & 2.01E-02 & 1 \\
\hline 4 & & 70 & 9.11 & 0.52 & 93 & 193 & 1,201 & 364 & 2,886 & 5.50E-02 & 1.72E-02 & 1 \\
\hline 9 & $\mathrm{q} / \mathrm{S}$ study & 90 & 9.18 & 0.52 & 78 & 550 & 3,139 & 921 & 4,018 & $1.45 \mathrm{E}-01$ & 4.44E-02 & 1 \\
\hline 10 & & 90 & 9.19 & 0.50 & 69 & 535 & 3,101 & 912 & 3,963 & 1.23E-01 & 3.75E-02 & 1 \\
\hline 11 & & 90 & 9.08 & 0.50 & 58 & 582 & 3,459 & 996 & 4,344 & 1.15E-01 & $3.48 \mathrm{E}-02$ & 1 \\
\hline 12 & & 90 & 9.08 & 0.51 & 51 & 750 & 4,263 & 1,249 & 5,383 & 1.32E-01 & 4.05E-02 & 1 \\
\hline 13 & & 90 & 9.13 & 0.52 & 40 & 741 & 4,695 & 1,288 & 5,456 & 9.55E-02 & 2.91E-02 & 1 \\
\hline 14 & & 90 & 9.13 & 0.51 & 32 & 912 & 5,826 & 1,514 & 6,533 & 9.33E-02 & 2.84E-02 & 1 \\
\hline 15 & & 90 & 9.19 & 0.50 & 20 & 1,054 & 6,932 & 1,838 & 7,285 & 6.92E-02 & 2.12E-02 & 1 \\
\hline 16 & & 90 & 9.19 & 0.51 & 7 & 1,527 & 13,123 & 2,707 & 10,310 & 3.63E-02 & $1.11 \mathrm{E}-02$ & 1 \\
\hline 92 & & 70 & 9.00 & 0.52 & 19 & 689 & 3,636 & 1,072 & 4,684 & 4.27E-02 & 1.46E-02 & 1 \\
\hline 93 & & 70 & 9.00 & 0.52 & 28 & 573 & 2,914 & 710 & 4,041 & 5.13E-02 & 1.75E-02 & 1 \\
\hline 94 & & 70 & 9.00 & 0.52 & 38 & 499 & 2,628 & 602 & 3,628 & 5.75E-02 & 1.96E-02 & 1 \\
\hline 95 & & 70 & 9.00 & 0.51 & 45 & 500 & 2,502 & 646 & 3,592 & 6.92E-02 & 2.37E-02 & 1 \\
\hline 96 & & 70 & 9.00 & 0.52 & 55 & 443 & 2,219 & 493 & 3,208 & 7.24E-02 & 2.49E-02 & 1 \\
\hline 97 & & 70 & 9.00 & 0.52 & 74 & 379 & 1,870 & 420 & 2,854 & 8.32E-02 & 2.82E-02 & 1 \\
\hline 68 & & 40 & 8.96 & 1.02 & 60 & 63 & 372 & 101 & 1,065 & 4.27E-03 & $9.46 \mathrm{E}-04$ & 1,3 \\
\hline 69 & & 40 & 8.96 & 0.76 & 60 & 53 & 235 & 79 & & 3.98E-03 & 2.06E-03 & 1,3 \\
\hline 70 & & 40 & 8.96 & 0.51 & 60 & & 200 & 66 & & 4.47E-03 & 3.56E-03 & 1,3 \\
\hline 71 & & 40 & 8.93 & 0.25 & 60 & & & 50 & & 5.50E-03 & 8.56E-03 & 1,3 \\
\hline 72 & & 40 & 8.93 & 1.01 & 40 & 81 & 606 & 129 & 1,204 & 3.89E-03 & 1.08E-03 & 1,3 \\
\hline
\end{tabular}


Table A.1. Experimental Parameters, Effluent Chemical Analysis, and Dissolution Rate Values For SPFT Experiments With LAWABP1 Glasses

\begin{tabular}{|c|c|c|c|c|c|c|c|c|c|c|c|c|}
\hline Expt. \# & WABP1 Glass & $\begin{array}{c}\text { Temp } \\
\left({ }^{\circ} \mathrm{C}\right)\end{array}$ & $\mathrm{pH}$ & $\begin{array}{c}\text { mass } \\
(\mathrm{g})\end{array}$ & $\begin{array}{c}\text { average } \\
\text { flow rate } \\
(\mathrm{mL} / \mathrm{d})\end{array}$ & $\begin{array}{c}\text { average } \\
\text { B conc. } \\
\text { (ppb) }\end{array}$ & $\begin{array}{c}\text { average } \\
\text { Na conc. } \\
\text { (ppb) }\end{array}$ & $\begin{array}{c}\text { average } \\
\text { Al conc. } \\
\text { (ppb) }\end{array}$ & $\begin{array}{c}\text { average } \\
\text { Si conc. } \\
\text { (ppb) }\end{array}$ & $\begin{array}{c}\text { average } \\
\text { B rate } \\
\left(\mathrm{g} \mathrm{m}^{-2} \mathrm{~d}^{-1}\right)\end{array}$ & $\begin{array}{c}2 \sigma_{r} \\
\text { uncertainty } \\
\left(\mathrm{g} \mathrm{m}^{-2} \mathrm{~d}^{-1}\right)\end{array}$ & Notes \\
\hline 73 & & 40 & 8.93 & 1.01 & 30 & 93 & 812 & 160 & 1,351 & "3.72E-03 & "1.02E-03 & $1,1,3$ \\
\hline 74 & & 40 & 8.91 & 1.01 & 60 & 80 & 455 & 91 & 1,072 & 3.72E-03 & 1.40E-03 & 1,3 \\
\hline 75 & q/S study & 40 & 8.91 & 0.75 & 60 & 73 & 426 & 111 & 1,110 & $6.46 E-03$ & 1.80E-03 & 1,3 \\
\hline 76 & & 40 & 8.91 & 0.51 & 60 & 59 & 353 & 97 & 1,087 & 7.94E-03 & 1.97E-03 & 1,3 \\
\hline 77 & & 40 & 8.90 & 0.25 & 60 & & & & & & & 1,3 \\
\hline 78 & & 40 & 8.90 & 1.01 & 40 & 84 & 703 & 138 & 1,225 & 4.27E-03 & $1.18 \mathrm{E}-03$ & 1,3 \\
\hline 79 & & 40 & 8.90 & 1.02 & 30 & 110 & 984 & 172 & 1,352 & $4.07 E-03$ & 1.42E-03 & 1,3 \\
\hline 146 & & 23 & 9.03 & 0.50 & 5 & 123 & 569 & 224 & & 1.72E-03 & 1.07E-03 & 1 \\
\hline 147 & & 23 & 9.03 & 0.51 & 10 & 86 & 405 & 156 & & 2.11E-03 & $1.01 \mathrm{E}-03$ & 1 \\
\hline 148 & & 23 & 9.03 & 0.51 & 15 & 68 & 314 & 121 & & 2.24E-03 & $9.81 \mathrm{E}-04$ & 1 \\
\hline 149 & & 23 & 9.03 & 0.51 & 20 & & 191 & & & & & 1 \\
\hline 150 & & 23 & 9.03 & 0.51 & 25 & & 156 & & & & & 1 \\
\hline 151 & & 23 & 9.03 & 0.51 & 30 & & 139 & & & & & 1 \\
\hline 134 & pH sweep & 90 & 2.19 & 0.51 & 80 & 7,381 & 38,962 & & 51,710 & $2.04 \mathrm{E}+00$ & 3.86E-01 & 1 \\
\hline 135 & & 90 & 3.78 & 0.51 & 80 & 1,564 & 8,523 & & 11,617 & & & 1,4 \\
\hline 136 & & 90 & 6.83 & 0.51 & 80 & 1,384 & 9,104 & & 3,190 & $3.55 \mathrm{E}-01$ & $6.93 \mathrm{E}-02$ & 1 \\
\hline 137 & & 90 & 8.07 & 0.52 & 80 & 558 & 3,687 & & 5,987 & 1.26E-01 & 2.59E-02 & 1 \\
\hline 138 & & 90 & 10.00 & 0.51 & 80 & 1,422 & 7,691 & & 11,102 & 3.72E-01 & 7.13E-02 & 1 \\
\hline 139 & & 90 & 11.06 & 0.52 & 80 & 5,726 & 31,023 & & 35,854 & $1.55 \mathrm{E}+00$ & 2.98E-01 & 1 \\
\hline 140 & & 90 & 2.19 & 0.51 & 80 & 9,593 & 51,699 & & 68,094 & $2.63 E+00$ & 5.02E-01 & 1 \\
\hline 141 & & 90 & 3.78 & 0.50 & 80 & & & & & & & 1,4 \\
\hline 142 & & 90 & 6.83 & 0.50 & 80 & 1,148 & 7,297 & & 3,005 & 2.88E-01 & 5.69E-02 & 1 \\
\hline 143 & & 90 & 8.07 & 0.51 & 80 & 552 & 3,471 & & 6,041 & 1.26E-01 & 2.56E-02 & 1 \\
\hline 144 & & 90 & 10.00 & 0.52 & 80 & 1,805 & 9,844 & & 13,596 & 4.79E-01 & $9.15 E-02$ & 1 \\
\hline 145 & & 90 & 11.06 & 0.51 & 80 & 6,559 & 29,468 & & 41,362 & $1.78 \mathrm{E}+00$ & 3.42E-01 & 1 \\
\hline 118 & & 70 & 2.11 & 0.50 & 60 & 8,212 & 43,422 & & 40,451 & $1.70 \mathrm{E}+00$ & 3.22E-01 & 1 \\
\hline 119 & & 70 & 3.76 & 0.50 & 60 & 459 & & & 4,864 & 7.41E-02 & 1.56E-02 & 1 \\
\hline 120 & & 70 & 7.09 & 0.52 & 60 & 356 & & & 2,216 & 5.25E-02 & 1.16E-02 & 1 \\
\hline 121 & & 70 & 8.06 & 0.51 & 60 & 258 & & & 3,801 & 3.31E-02 & 7.86E-03 & 1 \\
\hline
\end{tabular}


Table A.1. Experimental Parameters, Effluent Chemical Analysis, and Dissolution Rate Values For SPFT Experiments With LAWABP1 Glasses

\begin{tabular}{|c|c|c|c|c|c|c|c|c|c|c|c|c|}
\hline Expt. \# & WABP1 Glass & $\begin{array}{l}\text { Temp } \\
\left({ }^{\circ} \mathrm{C}\right)\end{array}$ & $\mathrm{pH}$ & $\begin{array}{c}\text { mass } \\
(\mathrm{g})\end{array}$ & $\begin{array}{c}\text { average } \\
\text { flow rate } \\
(\mathrm{mL} / \mathrm{d})\end{array}$ & $\begin{array}{c}\text { average } \\
\text { B conc. } \\
\text { (ppb) }\end{array}$ & $\begin{array}{c}\text { average } \\
\text { Na conc. } \\
\text { (ppb) }\end{array}$ & $\begin{array}{c}\text { average } \\
\text { Al conc. } \\
\text { (ppb) }\end{array}$ & $\begin{array}{c}\text { average } \\
\text { Si conc. } \\
\text { (ppb) }\end{array}$ & $\begin{array}{c}\text { average } \\
\text { B rate } \\
\left(\mathrm{g} \mathrm{m}^{-2} \mathrm{~d}^{-1}\right)\end{array}$ & $\begin{array}{c}2 \sigma_{r} \\
\text { uncertainty } \\
\left(\mathrm{g} \mathrm{m}^{-2} \mathrm{~d}^{-1}\right)\end{array}$ & Notes \\
\hline 122 & & 70 & 10.01 & 0.50 & 60 & 688 & & & $6,0,041$ & 1.23E-01 & 2.45E-02 & 1 \\
\hline 123 & & 70 & 10.99 & 0.51 & 60 & 3,904 & & & 25,504 & 7.94E-01 & $1.52 \mathrm{E}-01$ & 1 \\
\hline 124 & pH sweep & 70 & 2.11 & 0.51 & 60 & 11,726 & 23,438 & & 31,649 & $2.45 \mathrm{E}+00$ & 4.61E-01 & 1 \\
\hline 125 & & 70 & 3.76 & 0.51 & 60 & 487 & & & 4,896 & 8.13E-02 & 1.66E-02 & 1 \\
\hline 126 & & 70 & 7.09 & 0.51 & 60 & 345 & & & 2,239 & 5.13E-02 & 1.11E-02 & 1 \\
\hline 127 & & 70 & 8.06 & 0.51 & 60 & 256 & & & 3,522 & 3.24E-02 & 7.77E-03 & 1 \\
\hline 128 & & 70 & 10.01 & 0.50 & 60 & 861 & & & 7,058 & $1.58 \mathrm{E}-01$ & 3.13E-02 & 1 \\
\hline 129 & & 70 & 10.99 & 0.51 & 60 & 3,925 & & & 25,184 & 7.94E-01 & $1.52 \mathrm{E}-01$ & 1 \\
\hline 102 & & 40 & 2.15 & 0.51 & 40 & 9,585 & 49,855 & 17,293 & 24,664 & $1.29 \mathrm{E}+00$ & 2.50E-01 & 1 \\
\hline 103 & & 40 & 3.68 & 0.51 & 40 & 151 & 708 & 185 & 1,548 & 1.38E-02 & 3.13E-03 & 1 \\
\hline 164 & & 40 & 6.96 & 1.00 & 40 & & 307 & & & $3.55 E-03$ & $9.16 \mathrm{E}-04$ & 1,3 \\
\hline 105 & & 40 & 7.99 & 0.50 & 40 & & 357 & 96 & & $6.92 E-03$ & 1.11E-03 & 1,3 \\
\hline 106 & & 40 & 9.62 & 0.50 & 40 & 180 & 963 & 215 & 2,106 & $1.78 \mathrm{E}-02$ & $3.88 \mathrm{E}-03$ & 1 \\
\hline 107 & & 40 & 11.07 & 0.51 & 40 & 979 & 5,652 & 1,930 & 7,280 & $1.29 \mathrm{E}-01$ & $2.48 \mathrm{E}-02$ & 1 \\
\hline 108 & & 40 & 2.15 & 0.51 & 40 & 8,118 & 41,238 & 14,478 & 21,189 & $1.12 \mathrm{E}+00$ & 2.12E-01 & 1 \\
\hline 109 & & 40 & 3.68 & 0.50 & 40 & 138 & 638 & 160 & 1,503 & 1.20E-02 & 2.83E-03 & 1 \\
\hline 170 & & 40 & 6.96 & 1.00 & 14 & & 359 & & & $3.16 E-03$ & 8.91E-04 & 1 \\
\hline 111 & & 40 & 7.99 & 0.50 & 40 & & 366 & 107 & & 7.08E-03 & $9.34 \mathrm{E}-04$ & 1 \\
\hline 112 & & 40 & 9.62 & 0.52 & 40 & 150 & 909 & 270 & 1,912 & 1.35E-02 & 3.09E-03 & 1 \\
\hline 113 & & 40 & 11.07 & 0.50 & 40 & 634 & 3,598 & 1,286 & 4,785 & 7.94E-02 & 1.57E-02 & 1 \\
\hline 176 & & 23 & 2.13 & 0.50 & 20 & 15,740 & 83,266 & 27,608 & 42,391 & $1.10 \mathrm{E}+00$ & 2.07E-01 & 1 \\
\hline 177 & & 23 & 2.13 & 0.51 & 20 & 11,882 & 58,390 & 18,643 & 22,422 & 8.32E-01 & $1.56 \mathrm{E}-01$ & 1 \\
\hline 178 & & 23 & 2.13 & 0.50 & 20 & 14,318 & 75,520 & 25,057 & 33,784 & $1.00 \mathrm{E}+00$ & 1.89E-01 & 1 \\
\hline 179 & & 23 & 6.78 & 0.51 & 20 & & 216 & & & $1.58 E-03$ & 2.67E-04 & 1,3 \\
\hline 180 & & 23 & 6.78 & 0.51 & 20 & 36 & 189 & & & 1.17E-03 & 3.33E-04 & 1,3 \\
\hline 181 & & 23 & 6.78 & 0.51 & 20 & 32 & 204 & & & $1.45 E-03$ & 2.91E-04 & 1,3 \\
\hline 182 & & 23 & 9.04 & 0.50 & 20 & 68 & 228 & 50 & 217 & $1.74 E-03$ & 6.95E-04 & 1,3 \\
\hline 183 & & 23 & 9.04 & 0.50 & 20 & 42 & 206 & 44 & 227 & $1.20 \mathrm{E}-03$ & 3.94E-04 & 1 \\
\hline 184 & & 23 & 9.04 & 0.50 & 20 & 37 & 210 & 42 & 226 & 8.32E-04 & 3.39E-04 & 1 \\
\hline 193 & & 23 & 8.08 & 1.01 & 20 & & & & & & & 1 \\
\hline
\end{tabular}


Table A.1. Experimental Parameters, Effluent Chemical Analysis, and Dissolution Rate Values For SPFT Experiments With LAWABP1 Glasses

\begin{tabular}{|c|c|c|c|c|c|c|c|c|c|c|c|c|}
\hline Expt. \# & WABP1 Glass & $\begin{array}{c}\text { Temp } \\
\left({ }^{\circ} \mathrm{C}\right)\end{array}$ & $\mathrm{pH}$ & $\begin{array}{c}\text { mass } \\
(\mathrm{g})\end{array}$ & $\begin{array}{c}\text { average } \\
\text { flow rate } \\
(\mathrm{mL} / \mathrm{d})\end{array}$ & $\begin{array}{c}\text { average } \\
\text { B conc. } \\
\text { (ppb) }\end{array}$ & $\begin{array}{c}\text { average } \\
\text { Na conc. } \\
\text { (ppb) }\end{array}$ & $\begin{array}{c}\text { average } \\
\text { Al conc. } \\
\text { (ppb) }\end{array}$ & $\begin{array}{c}\text { average } \\
\text { Si conc. } \\
\text { (ppb) }\end{array}$ & $\begin{array}{c}\text { average } \\
\text { B rate } \\
\left(\mathrm{g} \mathrm{m}^{-2} \mathrm{~d}^{-1}\right)\end{array}$ & $\begin{array}{c}2 \sigma_{r} \\
\text { uncertainty } \\
\left(\mathrm{g} \mathrm{m}^{-2} \mathrm{~d}^{-1}\right)\end{array}$ & Notes \\
\hline 194 & & 23 & 8.08 & 1.01 & 20 & & & & & & & 1 \\
\hline 195 & & 23 & 8.08 & 1.00 & 20 & & & & & & & 1 \\
\hline 196 & pH sweep & 23 & 10.04 & 1.01 & 20 & 143 & 798 & & & $3.24 \mathrm{E}-03$ & 1.16E-03 & 1 \\
\hline 197 & & 23 & 10.04 & 1.01 & 20 & 134 & 749 & & & 2.88E-03 & 1.06E-03 & 1 \\
\hline 198 & & 23 & 10.04 & 1.01 & 20 & 135 & 798 & & & 2.95E-03 & $1.08 \mathrm{E}-03$ & 1 \\
\hline 199 & & 23 & 11.05 & 1.00 & 20 & 704 & 5,811 & & & 2.29E-02 & 7.73E-03 & 1 \\
\hline 200 & & 23 & 11.05 & 1.01 & 20 & 703 & 5,715 & & & 2.29E-02 & 7.71E-03 & 1 \\
\hline 201 & Q/K study & 23 & 11.05 & 1.00 & 20 & 736 & 5,899 & & & 2.40E-02 & 8.10E-03 & 1 \\
\hline 152 & 1.56E-04 & 90 & 8.95 & 0.51 & 80 & 711 & 4,141 & 1,150 & 4,390 & $1.70 \mathrm{E}-01$ & 5.30E-02 & 1,5 \\
\hline 153 & 8.71E-04 & 90 & 8.95 & 0.51 & 80 & 476 & 3,193 & 768 & 24,477 & $1.05 \mathrm{E}-01$ & 3.27E-02 & 1,5 \\
\hline 154 & 1.66 & 90 & 9.04 & 0.50 & 80 & 308 & 2,880 & 578 & 46,597 & 5.75E-02 & 1.83E-02 & 1,5 \\
\hline 155 & $2.45 E-03$ & 90 & 9.09 & 0.51 & 80 & 557 & 3,931 & 271 & 68,893 & 1.26E-01 & 3.97E-02 & 1,5 \\
\hline 156 & $3.20 \mathrm{E}-03$ & 90 & 9.05 & 0.51 & 80 & 550 & 3,720 & 142 & 89,963 & $1.26 \mathrm{E}-01$ & 3.91E-02 & 1,5 \\
\hline 157 & 3.77E-03 & 90 & 8.97 & 0.52 & 80 & 575 & 3,759 & 101 & 105,777 & 1.32E-01 & 4.13E-02 & 1,5 \\
\hline 158 & 1.71E-04 & 90 & 8.95 & 0.50 & 80 & 762 & 4,537 & 1,324 & 4,797 & 1.86E-01 & 5.74E-02 & 1,5 \\
\hline 159 & 9.59E-04 & 90 & 8.95 & 0.51 & 80 & 467 & 3,350 & 824 & 26,932 & 1.02E-01 & 3.20E-02 & 1,5 \\
\hline 160 & 1.76E-03 & 90 & 9.04 & 0.51 & 80 & 369 & 2,932 & 620 & 49,355 & 7.41E-02 & 2.35E-02 & 1,5 \\
\hline 161 & 2.49E-03 & 90 & 9.09 & 0.51 & 80 & 485 & 3,333 & 244 & 69,994 & 1.07E-01 & 3.35E-02 & 1,5 \\
\hline 162 & 3.33E-03 & 90 & 9.05 & 0.50 & 80 & 597 & 3,733 & 150 & 93,551 & 1.38E-01 & 4.32E-02 & 1,5 \\
\hline 163 & 4.05E-03 & 90 & 8.97 & 0.51 & 80 & 638 & 3,905 & 88 & 113,717 & $1.51 \mathrm{E}-01$ & 4.67E-02 & 1,5 \\
\hline 185 & 3.72E-03 & 90 & 9.03 & 0.58 & 20 & 2,553 & 14,346 & 186 & 104,614 & $1.51 \mathrm{E}-01$ & 4.12E-02 & 1,5 \\
\hline 186 & 2.83E-03 & 90 & 9.03 & 0.59 & 40 & 1,312 & 7,888 & 196 & 79,456 & $1.55 \mathrm{E}-01$ & 4.08E-02 & 1,5 \\
\hline 187 & 1.80E-03 & 90 & 9.03 & 0.58 & 60 & 732 & 4,755 & 242 & 50,595 & $1.29 \mathrm{E}-01$ & 3.51E-02 & 1,5 \\
\hline 188 & 8.81E-04 & 90 & 9.03 & 0.59 & 80 & 402 & 3,141 & 348 & 24,738 & 9.33E-02 & 2.46E-02 & 1,5 \\
\hline 189 & 3.61E-03 & 90 & 9.08 & 0.59 & 20 & 2,047 & 12,650 & 158 & 101,269 & $1.20 \mathrm{E}-01$ & 3.19E-02 & 1,5 \\
\hline 190 & $3.45 \mathrm{E}-03$ & 90 & 9.08 & 0.58 & 40 & 1,141 & 6,823 & 134 & 97,015 & $1.35 \mathrm{E}-01$ & 3.66E-02 & 1,5 \\
\hline 191 & $2.74 \mathrm{E}-03$ & 90 & 9.08 & 0.59 & 60 & 740 & 4,394 & 161 & 77,026 & $1.29 \mathrm{E}-01$ & 3.44E-02 & 1,5 \\
\hline 192 & $2.42 \mathrm{E}-03$ & 90 & 9.08 & 0.59 & 80 & 740 & 3,457 & 177 & 67,868 & 1.62E-01 & 4.58E-02 & 1,5 \\
\hline
\end{tabular}


Table A.1. Experimental Parameters, Effluent Chemical Analysis, and Dissolution Rate Values For SPFT Experiments With LAWABP1 Glasses

\begin{tabular}{|c|c|c|c|c|c|c|c|c|c|c|c|c|}
\hline Expt. \# & Description & $\begin{array}{c}\text { Temp } \\
\left({ }^{\circ} \mathrm{C}\right) \\
\end{array}$ & $\mathrm{pH}$ & $\begin{array}{c}\text { mass } \\
(\mathrm{g}) \\
\end{array}$ & $\begin{array}{c}\text { average } \\
\text { flow rate } \\
\text { (mL/d) } \\
\end{array}$ & $\begin{array}{c}\text { average } \\
\text { B conc. } \\
\text { (ppb) }\end{array}$ & $\begin{array}{c}\text { average } \\
\text { Na conc. } \\
\text { (ppb) }\end{array}$ & $\begin{array}{c}\text { average } \\
\text { Al conc. } \\
\text { (ppb) }\end{array}$ & $\begin{array}{c}\text { average } \\
\text { Si conc. } \\
\text { (ppb) }\end{array}$ & $\begin{array}{c}\text { average } \\
\text { B rate } \\
\left(\mathrm{g} \mathrm{m}^{-2} \mathrm{~d}^{-1}\right) \\
\end{array}$ & $\begin{array}{c}2 \sigma_{r} \\
\text { uncertainty } \\
\left(\mathrm{g} \mathrm{m}^{-2} \mathrm{~d}^{-1}\right) \\
\end{array}$ & Notes \\
\hline & Q/K study & & & & & & & & & & & \\
\hline 98 & 3.77E-04 & 70 & 9.02 & 0.52 & 50 & 386 & & 656 & 10,595 & 6.33E-02 & 1.90E-02 & 1,5 \\
\hline 99 & 3.66E-04 & 70 & 9.02 & 0.51 & 60 & 321 & & 522 & 10,272 & 6.34E-02 & 1.92E-02 & 1,5 \\
\hline 100 & 6.96E-04 & 70 & 9.12 & 0.52 & 50 & 332 & & 535 & 19,538 & 5.42E-02 & 1.63E-02 & 1,5 \\
\hline 101 & 6.80E-04 & 70 & 9.12 & 0.52 & 60 & 273 & & 443 & 19,088 & 5.29E-02 & 1.58E-02 & 1,5 \\
\hline \multirow[t]{2}{*}{114} & 1.07E-03 & 70 & 9.05 & 0.51 & 50 & 241 & 1,293 & 378 & 29,988 & 3.72E-02 & 1.17E-02 & 1,5 \\
\hline & $\mathrm{Q} / \mathrm{K}$ study & & & & & & & & & & & \\
\hline 115 & 1.07E-03 & 70 & 9.05 & 0.51 & 60 & 211 & 1,200 & 328 & 29,968 & 3.89E-02 & 1.21E-02 & 1,5 \\
\hline 116 & 7.35E-04 & 70 & 9.05 & 0.51 & 50 & 166 & 1,451 & 248 & 20,656 & 2.51E-02 & 7.85E-03 & 1,5 \\
\hline 117 & 7.42E-04 & 70 & 9.05 & 0.51 & 60 & 146 & 1,301 & 223 & 20,854 & 2.69E-02 & 8.52E-03 & 1,5 \\
\hline 130 & 1.67E-03 & 70 & 9.29 & 0.50 & 60 & 143 & 1,069 & 227 & 46,969 & 2.04E-02 & 6.40E-03 & 1,5 \\
\hline 131 & & 70 & 9.29 & 0.50 & 60 & 140 & 866 & 201 & 47,090 & $=-02$ & 7.51E-03 & 1,5 \\
\hline 132 & 1.9 & 70 & 9.29 & 0.50 & 60 & 146 & 819 & 217 & 54,904 & 2.09E-02 & 6.58E-03 & 1,5 \\
\hline 133 & 1.94E-03 & 70 & 9.29 & 0.51 & 60 & 122 & 764 & 189 & 54,608 & 2.04E-02 & 6.36E-03 & 1,5 \\
\hline 206 & 4.56E-03 & 70 & 9.03 & 0.51 & 60 & 129 & 1,002 & $<25$ & 128,054 & 2.51E-02 & 7.72E-03 & 1,5 \\
\hline \multirow[t]{2}{*}{207} & 4.58E-03 & 70 & 9.03 & 0.51 & 60 & 123 & 969 & $<25$ & 128,687 & 2.34E-02 & 7.32E-03 & 1,5 \\
\hline & $\mathrm{Q} / \mathrm{K}$ study & & & & & & & & & & & \\
\hline 17 & 3.40E-05 & 40 & 9.10 & 0.50 & 29 & 93 & 519 & 160 & 956 & 7.94E-03 & $2.45 \mathrm{E}-03$ & 1,5 \\
\hline 18 & 3.69E-04 & 40 & 9.09 & 0.50 & 31 & 57 & 365 & 82 & 10,366 & 5.13E-03 & $1.60 \mathrm{E}-03$ & 1,5 \\
\hline 19 & 7.24E-04 & 40 & 9.08 & 0.51 & 30 & 44 & 352 & 55 & 20,349 & 3.72E-03 & 1.15E-03 & 1,5 \\
\hline 20 & 1.43E-03 & 40 & 9.04 & 0.52 & 30 & 33 & 391 & 27 & 39,818 & $1.66 E-03$ & 5.13E-04 & 1,5 \\
\hline 21 & $2.10 \mathrm{E}-03$ & 40 & 8.72 & 0.50 & 30 & 25 & 308 & $<10$ & 59,129 & $1.95 E-03$ & 5.18E-04 & 1,5 \\
\hline 22 & 2.77E-03 & 40 & 9.08 & 0.51 & 30 & 29 & 324 & $<10$ & 77,731 & $1.95 E-03$ & $6.21 \mathrm{E}-04$ & 1,5 \\
\hline 23 & 3.27E-05 & 40 & 9.07 & 0.50 & 30 & 92 & 509 & 155 & 919 & 8.71E-03 & 2.73E-03 & 1,5 \\
\hline 24 & 3.97E-04 & 40 & 9.06 & 0.51 & 30 & 48 & 370 & 70 & 11,152 & 4.07E-03 & 1.26E-03 & 1,5 \\
\hline 25 & 7.06E-04 & 40 & 9.04 & 0.50 & 30 & 41 & 349 & 53 & 19,832 & 3.39E-03 & $1.05 \mathrm{E}-03$ & 1,5 \\
\hline 26 & 1.43E-03 & 40 & 9.06 & 0.50 & 30 & 32 & 330 & 26 & 40,269 & $2.34 E-03$ & $7.45 \mathrm{E}-04$ & 1,5 \\
\hline 27 & 2.08E-03 & 40 & 9.06 & 0.50 & 30 & 23 & 332 & $<10$ & 58,343 & $1.35 E-03$ & 4.37E-04 & 1,5 \\
\hline 28 & 2.64E-03 & 40 & 9.09 & 0.50 & 30 & 19 & $<300$ & $<10$ & 74,106 & $1.00 E-03$ & 3.30E-04 & 1,5 \\
\hline E24 & 2.26E-03 & 40 & 8.00 & 1.00 & 10 & 117 & 1,489 & & 63,386 & 1.95E-03 & 3.30E-04 & 1,5 \\
\hline
\end{tabular}


Table A.1. Experimental Parameters, Effluent Chemical Analysis, and Dissolution Rate Values For SPFT Experiments With LAWABP1 Glasses

\begin{tabular}{|c|c|c|c|c|c|c|c|c|c|c|c|c|}
\hline Expt. \# & AWABP1 Glass & $\begin{array}{c}\text { Temp } \\
\left({ }^{\circ} \mathrm{C}\right) \\
\end{array}$ & $\mathrm{pH}$ & $\begin{array}{c}\text { mass } \\
(\mathrm{g}) \\
\end{array}$ & $\begin{array}{c}\text { average } \\
\text { flow rate } \\
(\mathrm{mL} / \mathrm{d}) \\
\end{array}$ & $\begin{array}{c}\text { average } \\
\text { B conc. } \\
\text { (ppb) }\end{array}$ & $\begin{array}{c}\text { average } \\
\text { Na conc. } \\
\text { (ppb) }\end{array}$ & $\begin{array}{c}\text { average } \\
\text { Al conc. } \\
\text { (ppb) }\end{array}$ & $\begin{array}{c}\text { average } \\
\text { Si conc. } \\
\text { (ppb) }\end{array}$ & $\begin{array}{c}\text { average } \\
\text { B rate } \\
\left(\mathrm{g} \mathrm{m}^{-2} \mathrm{~d}^{-1}\right) \\
\end{array}$ & $\begin{array}{c}2 \sigma_{r} \\
\text { uncertainty } \\
\left(\mathrm{g} \mathrm{m}^{-2} \mathrm{~d}^{-1}\right) \\
\end{array}$ & Notes \\
\hline & Q/K study & & & & & & & & & & & \\
\hline 208 & 3.06E-04 & 26 & 9.07 & 1.02 & 10 & 36 & 455 & 70 & 8,606 & $5.14 \mathrm{E}-04$ & 8.65E-05 & 1,5 \\
\hline 209 & $\begin{array}{l}\text { 3.07E-04 } \\
\text { Q/K study }\end{array}$ & 26 & 9.07 & 1.01 & 10 & 37 & 416 & 65 & 8,612 & 5.28E-04 & 8.91E-05 & 1,5 \\
\hline 210 & 5.59E-04 & 26 & 9.06 & 1.02 & 10 & 22 & 403 & $<50$ & 15,708 & 2.93E-04 & 5.00E-05 & 1,5 \\
\hline 211 & 5.63E-04 & 26 & 9.06 & 1.01 & 10 & 21 & 398 & $<50$ & 15,810 & $2.83 E-04$ & 4.85E-05 & 1,5 \\
\hline 212 & $\begin{array}{l}1.15 \mathrm{E}-03 \\
\mathrm{Q} / \mathrm{K} \text { study }\end{array}$ & 26 & 9.05 & 1.01 & 10 & 13 & 427 & $<50$ & 32,250 & $1.50 E-04$ & 2.63E-05 & 1,5 \\
\hline 213 & 1.15E-03 & 26 & 9.05 & 1.02 & 10 & 12 & 423 & $<50$ & 32,289 & $1.23 E-04$ & 2.20E-05 & 1,5 \\
\hline 214 & 1.15E-03 & 26 & 9.03 & 1.01 & 10 & 9 & 398 & $<50$ & 32,289 & $8.40 E-05$ & 1.56E-05 & 1,5 \\
\hline 215 & 1.15 & 26 & 9.03 & 1.01 & 10 & 9 & 375 & $<50$ & 32,289 & 7.33E-05 & 1.40E-05 & 1,5 \\
\hline 216 & 1.7 & 26 & 9.04 & 1.01 & 10 & 13 & 453 & $<50$ & 48,167 & $1.40 E-04$ & 2.47E-05 & 1,5 \\
\hline 217 & 1.73E-03 & 26 & 9.04 & 1.01 & 10 & 12 & 435 & $<50$ & 48,497 & $1.35 E-04$ & $2.40 \mathrm{E}-05$ & 1,5 \\
\hline 218 & 2.32E-03 & 26 & 9.18 & 1.04 & 10 & 12 & 474 & $<50$ & 65,139 & 1.34E-04 & 2.37E-05 & 1,5 \\
\hline 219 & 2.33E-03 & 26 & 9.18 & 1.01 & 10 & 12 & 450 & $<50$ & 65,590 & $1.32 E-04$ & 2.34E-05 & 1,5 \\
\hline 220 & 2.64E-03 & 26 & 9.16 & 1.02 & 10 & 13 & 431 & $<50$ & 74,083 & $1.45 E-04$ & 2.56E-05 & 1,5 \\
\hline 221 & $2.66 \mathrm{E}$ & 26 & 9.16 & 1.03 & 10 & 14 & 477 & $<50$ & 74,633 & $1.65 E-04$ & 2.86E-05 & 1,5 \\
\hline 222 & 3.42E-03 & 26 & 9.16 & 1.02 & 10 & 24 & 417 & $<50$ & 96,183 & $3.30 E-04$ & 5.62E-05 & 1,5 \\
\hline 223 & $\begin{array}{l}\text { 3.42E-03 } \\
\text { Al-sweep }\end{array}$ & 26 & 9.16 & 1.02 & 10 & 24 & 408 & $<50$ & 96,058 & $3.21 E-04$ & $5.48 \mathrm{E}-05$ & 1,5 \\
\hline 5 & $0 \mu \mathrm{mol}$ Al & 40 & 9.05 & 0.51 & 32 & 178 & 1,180 & 312 & 1,404 & 1.91E-02 & $3.65 \mathrm{E}-03$ & 1,6 \\
\hline 6 & $20 \mu \mathrm{mol} \mathrm{Al}$ & 40 & 9.03 & 0.50 & 27 & 123 & 893 & 640 & 985 & 1.17E-02 & 1.85E-03 & 1,6 \\
\hline 7 & $35 \mu \mathrm{mol} \mathrm{Al}$ & 40 & 9.04 & 0.52 & 30 & 102 & 786 & 793 & 831 & 9.77E-03 & 1.93E-03 & 1,6 \\
\hline 8 & $\begin{array}{l}50 \mu \mathrm{mol} \text { Al } \\
\text { Si/Al sweep }\end{array}$ & 40 & 9.01 & 0.51 & 30 & 88 & 700 & 914 & 715 & 8.13E-03 & $1.60 \mathrm{E}-03$ & 1,6 \\
\hline 80 & $0 \mathrm{Si} / 0 \mu \mathrm{M} \mathrm{Al}$ & 90 & 8.86 & 0.51 & 80 & 968 & 5,291 & 1,628 & 6,070 & 2.57E-01 & 4.92E-02 & 1,7 \\
\hline 81 & $0 \mathrm{Si} / 40 \mu \mathrm{M} \mathrm{Al}$ & 90 & 8.97 & 0.51 & 80 & 850 & 4,692 & 2,432 & 5,363 & 2.19E-01 & 4.29E-02 & 1,7 \\
\hline 82 & $0 \mathrm{Si} / 75 \mu \mathrm{M} \mathrm{Al}$ & 90 & 8.96 & 0.50 & 80 & 869 & 4,833 & 3,313 & 5,635 & $2.24 \mathrm{E}-01$ & 4.39E-02 & 1,7 \\
\hline 83 & $0 \mathrm{Si} / 100 \mu \mathrm{M} \mathrm{Al}$ & 90 & 8.96 & 0.51 & 80 & 768 & 4,288 & 2,661 & 5,236 & 2.00E-01 & 3.86E-02 & 1,7 \\
\hline
\end{tabular}


Table A.1. Experimental Parameters, Effluent Chemical Analysis, and Dissolution Rate Values For SPFT Experiments With LAWABP1 Glasses

\begin{tabular}{|c|c|c|c|c|c|c|c|c|c|c|c|c|}
\hline Expt. \# & LAWABP1 Glass & $\begin{array}{c}\text { Temp } \\
\left({ }^{\circ} \mathrm{C}\right) \\
\end{array}$ & $\mathrm{pH}$ & $\begin{array}{c}\text { mass } \\
(\mathrm{g}) \\
\end{array}$ & $\begin{array}{c}\text { average } \\
\text { flow rate } \\
(\mathrm{mL} / \mathrm{d}) \\
\end{array}$ & $\begin{array}{c}\text { average } \\
\text { B conc. } \\
\text { (ppb) }\end{array}$ & $\begin{array}{c}\text { average } \\
\text { Na conc. } \\
\text { (ppb) }\end{array}$ & $\begin{array}{c}\text { average } \\
\text { Al conc. } \\
\text { (ppb) }\end{array}$ & $\begin{array}{c}\text { average } \\
\text { Si conc. } \\
\text { (ppb) }\end{array}$ & $\begin{array}{c}\text { average } \\
\text { B rate } \\
\left(\mathrm{g} \mathrm{m}^{-2} \mathrm{~d}^{-1}\right) \\
\end{array}$ & $\begin{array}{c}2 \sigma_{r} \\
\text { uncertainty } \\
\left(\mathrm{g} \mathrm{m}^{-2} \mathrm{~d}^{-1}\right) \\
\end{array}$ & Notes \\
\hline & Si/Al sweep & & & & & & & & & & & \\
\hline 84 & $40 \% \mathrm{Si} / 0 \mu \mathrm{M} \mathrm{Al}$ & 90 & 8.88 & 0.50 & 80 & 349 & 2,768 & 309 & 95,410 & 8.32E-02 & 1.66E-02 & 1,7 \\
\hline 85 & $40 \% \mathrm{Si} / 40 \mu \mathrm{M} \mathrm{Al}$ & 90 & 8.89 & 0.50 & 80 & 450 & 3,022 & 1,171 & 92,390 & $1.12 \mathrm{E}-01$ & $2.19 \mathrm{E}-02$ & 1,7 \\
\hline 86 & $40 \% \mathrm{Si} / 75 \mu \mathrm{M} \mathrm{Al}$ & 90 & 8.88 & 0.51 & 80 & 475 & 3,102 & 2,108 & 93,890 & 1.17E-01 & 2.33E-02 & 1,7 \\
\hline 87 & $40 \% \mathrm{Si} / 100 \mu \mathrm{M} \mathrm{Al}$ & 90 & 8.87 & 0.51 & 80 & 596 & 3,831 & 2,769 & 91,284 & $1.48 \mathrm{E}-01$ & 2.96E-02 & 1,7 \\
\hline 88 & $60 \% \mathrm{Si} / 0 \mu \mathrm{M} \mathrm{Al}$ & 90 & 9.07 & 0.50 & 80 & 467 & 3,025 & 91 & 139,411 & $1.15 E-01$ & 2.28E-02 & 1,7 \\
\hline 89 & $60 \% \mathrm{Si} / 40 \mu \mathrm{M} \mathrm{Al}$ & 90 & 9.12 & 0.51 & 80 & 549 & 3,411 & 1,116 & 135,269 & $1.38 \mathrm{E}-01$ & 2.72E-02 & 1,7 \\
\hline 90 & $60 \% \mathrm{Si} / 75 \mu \mathrm{M} \mathrm{Al}$ & 90 & 9.06 & 0.51 & 80 & 523 & 3,129 & 2,023 & 127,451 & 1.32 & $2.58 \mathrm{E}-02$ & 1,7 \\
\hline 91 & $\begin{array}{c}60 \% \mathrm{Si} / 100 \mu \mathrm{M} \mathrm{Al} \\
\mathrm{Si} / \mathrm{Al} \text { sweep }\end{array}$ & 90 & 9.05 & 0.51 & 80 & 514 & 3,122 & 2,580 & 124,532 & $1.29 \mathrm{E}-01$ & 2.53E-02 & 1,7 \\
\hline 56 & $0 \mathrm{Si}, 0$ & 70 & 9.02 & 0.50 & 60 & 538 & 2,7 & 933 & & & -02 & 1,7 \\
\hline 57 & & 70 & 8.93 & 0.50 & 6 & 423 & 2,091 & 1,603 & 3,340 & & 1.53E-02 & 1,7 \\
\hline 58 & uM Al & 70 & 8.88 & 0.51 & 6 & 513 & 2,753 & 2,385 & 3,841 & -02 & 1.89E-02 & 1,7 \\
\hline 59 & $0 \mathrm{Si} / 90 \mu \mathrm{M} \mathrm{Al}$ & 70 & 8.97 & 0.51 & 60 & 455 & 2,347 & 2,855 & 3,589 & 8.32 & 1.66E-02 & 1,7 \\
\hline 60 & $40 \% \mathrm{Si} / 0 \mu \mathrm{M} \mathrm{Al}$ & 70 & 8.88 & 0.51 & 60 & 167 & 1,352 & 86 & 69,326 & 2.40 & 5.36E-03 & 1,7 \\
\hline 61 & $\mu \mathrm{M} \mathrm{Al}$ & 70 & 9.09 & 0.50 & 60 & 128 & 1,089 & 971 & 65,596 & 1.5 & 3.90E-03 & 1,7 \\
\hline 62 & $\mathrm{M} \mathrm{Al}$ & 70 & 9.06 & 0.50 & 60 & 89 & 1,089 & 1,547 & 71,110 & 8.1 & 2.49E-03 & 1,7 \\
\hline 63 & $40 \% \mathrm{Si} / 90 \mu \mathrm{M} \mathrm{Al}$ & 70 & 9.04 & 0.50 & 60 & 152 & 1,193 & 2,157 & 68,480 & $1.32 \mathrm{E}$ & 4.26E-03 & 1,7 \\
\hline 64 & $60 \% \mathrm{Si} / 0 \mu \mathrm{M} \mathrm{Al}$ & 70 & 8.87 & 0.50 & 60 & 180 & 1,302 & 55 & 91,814 & 2.69E-02 & 5.85E-03 & 1,7 \\
\hline 65 & $60 \% \mathrm{Si} / 35 \mu \mathrm{M} \mathrm{Al}$ & 70 & 9.05 & 0.51 & 60 & 167 & 1,202 & 813 & 96,479 & $2.45 \mathrm{E}-02$ & $5.38 \mathrm{E}-03$ & 1,7 \\
\hline 66 & $60 \% \mathrm{Si} / 60 \mu \mathrm{M} \mathrm{Al}$ & 70 & 9.06 & 0.51 & 60 & 151 & 1,146 & 1,368 & 97,295 & 2.14E-02 & 4.77E-03 & 1,7 \\
\hline 67 & $\begin{array}{c}60 \% \mathrm{Si} / 90 \mu \mathrm{M} \mathrm{Al} \\
\mathrm{Si} / \mathrm{Al} \text { sweep }\end{array}$ & 70 & 9.02 & 0.50 & 60 & 183 & 1,306 & 2,167 & 99,237 & $2.75 \mathrm{E}-02$ & 5.99E-03 & 1,7 \\
\hline 44 & $0 \mathrm{Si} / 0 \mu \mathrm{M}$ Al & 40 & 9.00 & 1.00 & 30 & 141 & 1,030 & 163 & 1,479 & $6.76 \mathrm{E}-03$ & $2.32 \mathrm{E}-03$ & 1,7 \\
\hline 45 & $0 \mathrm{Si} / 20 \mu \mathrm{M} \mathrm{Al}$ & 40 & 9.00 & 1.00 & 30 & 89 & 643 & 495 & 1,041 & 4.17E-03 & 1.41E-03 & 1,7 \\
\hline 46 & $\begin{array}{c}0 \mathrm{Si} / 35 \mu \mathrm{M} \mathrm{Al} \\
\mathrm{Si} / \mathrm{Al} \text { sweep }\end{array}$ & 40 & 9.00 & 1.01 & 30 & 61 & 638 & 857 & 843 & 2.63E-03 & $9.13 E-04$ & 1,7 \\
\hline 47 & $0 \mathrm{Si} / 50 \mu \mathrm{M} \mathrm{Al}$ & 40 & 9.00 & 1.02 & 30 & 44 & 690 & 1,297 & 768 & & $6.18 \mathrm{E}-04$ & 1,7 \\
\hline 48 & $40 \% \mathrm{Si} / 0 \mu \mathrm{M} \mathrm{Al}$ & 40 & 9.00 & 1.02 & 30 & 45 & 622 & 35 & 42,206 & 1.82E-03 & 6.37E-04 & 1,7 \\
\hline 49 & $40 \% \mathrm{Si} / 20 \mu \mathrm{M} \mathrm{Al}$ & 40 & 9.00 & 1.01 & 30 & 40 & 609 & 547 & 38,027 & 1.58E-03 & 5.53E-04 & 1,7 \\
\hline
\end{tabular}


Table A.1. Experimental Parameters, Effluent Chemical Analysis, and Dissolution Rate Values For SPFT Experiments With LAWABP1 Glasses

\begin{tabular}{|c|c|c|c|c|c|c|c|c|c|c|c|c|}
\hline Expt. \# & LAWABP1 Glass & $\begin{array}{c}\text { Temp } \\
\left({ }^{\circ} \mathrm{C}\right) \\
\end{array}$ & $\mathrm{pH}$ & $\begin{array}{c}\text { mass } \\
(\mathrm{g}) \\
\end{array}$ & $\begin{array}{c}\text { average } \\
\text { flow rate } \\
(\mathrm{mL} / \mathrm{d}) \\
\end{array}$ & $\begin{array}{c}\text { average } \\
\text { B conc. } \\
\text { (ppb) }\end{array}$ & $\begin{array}{c}\text { average } \\
\text { Na conc. } \\
\text { (ppb) }\end{array}$ & $\begin{array}{c}\text { average } \\
\text { Al conc. } \\
\text { (ppb) }\end{array}$ & $\begin{array}{c}\text { average } \\
\text { Si conc. } \\
\text { (ppb) }\end{array}$ & $\begin{array}{c}\text { average } \\
\text { B rate } \\
\left(\mathrm{g} \mathrm{m}^{-2} \mathrm{~d}^{-1}\right) \\
\end{array}$ & $\begin{array}{c}2 \sigma_{r} \\
\text { uncertainty } \\
\left(\mathrm{g} \mathrm{m}^{-2} \mathrm{~d}^{-1}\right) \\
\end{array}$ & Notes \\
\hline 50 & $40 \% \mathrm{Si} / 35 \mu \mathrm{M} \mathrm{Al}$ & 40 & 9.00 & 1.00 & 30 & 36 & 665 & 986 & 38,792 & 1.26E-03 & 4.79E-04 & 1,7 \\
\hline 51 & $40 \% \mathrm{Si} / 50 \mu \mathrm{M} \mathrm{Al}$ & 40 & 9.00 & 1.02 & 30 & 38 & 652 & 1,479 & 40,267 & 1.48E-03 & 5.19E-04 & 1,7 \\
\hline 52 & $60 \% \mathrm{Si} / 0 \mu \mathrm{M} \mathrm{Al}$ & 40 & 9.00 & 1.01 & 30 & 42 & 609 & 28 & 53,145 & $1.70 \mathrm{E}-03$ & 5.90E-04 & 1,7 \\
\hline 53 & $60 \% \mathrm{Si} / 20 \mu \mathrm{M} \mathrm{Al}$ & 40 & 9.00 & 1.00 & 30 & 31 & 600 & 561 & 55,570 & 1.10E-03 & 3.96E-04 & 1,7 \\
\hline 54 & $60 \% \mathrm{Si} / 35 \mu \mathrm{M} \mathrm{Al}$ & 40 & 9.00 & 1.01 & 30 & 41 & 605 & 864 & 39,553 & $1.58 \mathrm{E}-03$ & 5.61E-04 & 1,7 \\
\hline 55 & $60 \% \mathrm{Si} / 50 \mu \mathrm{M} \mathrm{Al}$ & 40 & 9.00 & 1.00 & 30 & 39 & 632 & 1,379 & 50,561 & $1.55 E-03$ & 5.39E-04 & 1,7 \\
\hline 202 & 50 ppm humic & 90 & 9.03 & 0.51 & 80 & 725 & 4,138 & 1,417 & 4,730 & $1.85 \mathrm{E}-01$ & 3.62E-02 & 1 \\
\hline 203 & 50 ppm humic & 90 & 9.03 & 0.50 & 80 & 675 & 3,815 & 1,348 & 4,494 & 1.73E-01 & 3.37E-02 & 1 \\
\hline 204 & 0 ppm humic & 90 & 9.05 & 0.50 & 80 & 584 & 3,225 & 964 & 3,477 & $1.55 \mathrm{E}-01$ & 2.89E-02 & 1 \\
\hline 205 & 0 ppm humic & 90 & 9.05 & 0.51 & 80 & 556 & 3,182 & 931 & 3,448 & 1.49E-01 & 2.74E-02 & 1 \\
\hline 224 & 10 ppm fulvic & 90 & 9.08 & 0.52 & 80 & 607 & 3,560 & 982 & 3,821 & $1.60 \mathrm{E}-01$ & 3.09E-02 & 1 \\
\hline 225 & 10 ppm fulvic & 90 & 9.08 & 0.51 & 80 & 611 & 3,587 & 992 & 3,879 & $1.59 \mathrm{E}-01$ & $3.08 \mathrm{E}-02$ & 1 \\
\hline 226 & 0 ppm fulvic & 90 & 9.08 & 0.51 & 80 & 566 & 3,236 & 878 & 3,489 & 1.49E-01 & 2.88E-02 & 1 \\
\hline 227 & 0 ppm fulvic & 90 & 9.08 & 0.51 & 80 & 528 & 3,146 & 848 & 3,325 & 1.38E-01 & 2.68E-02 & 1 \\
\hline
\end{tabular}

Symbols such as $q, S, Q$, and $K$ are explained in text.

Bold, italicized values are uncertain due to low concentration of elements in the effluent solution. These rates are the reported maximum value.

Blank: Concentration of element below lower limit of quantification or rate not reported due to experimental difficulties.

Notes:

1. Surface area $=0.020 \mathrm{~m}^{2} / \mathrm{g}$ estimated by use of geometric formula.

2. Glass coupons with surface area $=0.0013 \mathrm{~m}^{2} / \mathrm{g}$ based on measurements of dimensions of coupons with a caliper.

3. Reported rates an average of several values ( $\mathrm{Na}, \mathrm{Al}, \mathrm{Si}, \mathrm{B}$, as appropriate).

4. Solution $\mathrm{pH}$ value not maintained at constant value.

5. Value in column under heading: " $\mathrm{Q} / \mathrm{K}$ study" is the molar concentration of $\mathrm{Si}$ in solution.

6. Solution also contained $0.05 \mathrm{M} \mathrm{LiCl}$.

7. Under column heading: "Si/Al sweep", the first value is the percentage of $\mathrm{SiO}_{2}(\mathrm{aq})$ towards saturation in silica and the second is the concentration of $\mathrm{Al}$ in solution in $\mu \mathrm{mol} / \mathrm{L}$. 
Table A.2. Experimental Parameters, Effluent Chemical Analysis, and Dissolution Rate Values For SPFT Experiments With LAWABP1 Glasses

\begin{tabular}{|c|c|c|c|c|c|c|c|c|c|c|c|c|}
\hline Expt. \# & P-31 Glass & $\begin{array}{l}\text { Temp } \\
\left({ }^{\circ} \mathrm{C}\right)\end{array}$ & $\mathrm{pH}$ & $\begin{array}{c}\text { mass } \\
(\mathrm{g})\end{array}$ & $\begin{array}{c}\text { average } \\
\text { flow rate } \\
(\mathrm{mL} / \mathrm{d})\end{array}$ & $\begin{array}{c}\text { average } \\
\text { B conc. } \\
\text { (ppb) }\end{array}$ & $\begin{array}{c}\text { average } \\
\text { Na conc. } \\
\text { (ppb) }\end{array}$ & $\begin{array}{c}\text { average } \\
\text { Al conc. } \\
\text { (ppb) }\end{array}$ & $\begin{array}{c}\text { average } \\
\text { Si conc. } \\
\text { (ppb) }\end{array}$ & $\begin{array}{c}\text { average } \\
\mathrm{B} \text { rate } \\
\left(\mathrm{g} \mathrm{m}^{-2} \mathrm{~d}^{-1}\right)\end{array}$ & $\begin{array}{c}2 \sigma_{r} \\
\text { uncertainty } \\
\left(\mathrm{g} \mathrm{m}^{-2} \mathrm{~d}^{-1}\right)\end{array}$ & Notes \\
\hline & Si sweep & & & & & & & & & & & \\
\hline 13 & 1.37E-05 & 26 & 9.08 & 0.5 & 10 & 1,216 & 5,401 & $<50$ & $<500$ & $1.50 \mathrm{E}-02$ & $5.09 \mathrm{E}-03$ & 1,5 \\
\hline 1 & 3.23E-04 & 26 & 9.07 & 0.5 & 10 & 1,239 & 5,535 & $<50$ & 9,074 & 1.53E-02 & 5.19E-03 & 1,5 \\
\hline 2 & 3.17E-04 & 26 & 9.07 & 0.5 & 10 & 1,226 & 5,351 & $<50$ & 8,911 & 1.51E-02 & 5.13E-03 & 1,5 \\
\hline 3 & 5.83E-04 & 26 & 9.06 & 0.5 & 10 & 1,255 & 5,530 & $<50$ & 16,380 & 1.55E-02 & 5.27E-03 & 1,5 \\
\hline 4 & 5.79E-04 & 26 & 9.06 & 0.5 & 10 & 1,278 & 5,628 & $<50$ & 16,259 & 1.58E-02 & 5.37E-03 & 1,5 \\
\hline 5 & 1.20E-03 & 26 & 9.05 & 0.5 & 10 & 1,448 & 6,321 & $<50$ & 33,684 & 1.81E-02 & $6.14 \mathrm{E}-03$ & 1,5 \\
\hline 6 & $1.20 \mathrm{E}-03$ & 26 & 9.05 & 0.5 & 10 & 1,501 & 6,534 & $<50$ & 33,635 & 1.88E-02 & 6.38E-03 & 1,5 \\
\hline 7 & 1.72E-03 & 26 & 9.04 & 0.5 & 10 & 1,375 & 5,874 & $<50$ & 48,301 & 1.71E-02 & 5.81E-03 & 1,5 \\
\hline 8 & 1.73E-03 & 26 & 9.04 & 0.5 & 10 & 1,331 & 5,773 & $<50$ & 48,630 & 1.65E-02 & 5.61E-03 & 1,5 \\
\hline 9 & 2.31E-03 & 26 & 9.18 & 0.5 & 10 & 1,318 & 5,640 & $<50$ & 64,992 & 1.63E-02 & 5.55E-03 & 1,5 \\
\hline 10 & 2.61E-03 & 26 & 9.18 & 0.5 & 10 & 1,279 & 5,547 & $<50$ & 73,407 & 1.58E-02 & 5.37E-03 & 1,5 \\
\hline 11 & 2.63E-03 & 26 & 9.16 & 0.5 & 10 & 1,263 & 5,525 & $<50$ & 73,795 & 1.56E-02 & 5.30E-03 & 1,5 \\
\hline 12 & 2.31E-03 & 26 & 9.16 & 0.5 & 10 & 1,291 & 5,777 & $<50$ & 64,993 & 1.60E-02 & 5.43E-03 & 1,5 \\
\hline
\end{tabular}

Notes:

1. Surface area $=0.020 \mathrm{~m}^{2} / \mathrm{g}$ estimated by use of geometric formula.

5. Value in column under heading: "Description" is the molar concentration of $\mathrm{Si}$ in solution. 
No. of

Copies

\section{OFFSITE}

1

Argonne National Laboratory

Building 205

9700 South Cass Avenue

Argonne, IL 60439-4837

Attn: William L. Ebert

$1 \quad$ Lawrence Livermore National

Laboratory

Mail Code L-219

7000 East Ave

Livermore, CA 94550-9234

Attn: William L. Bourcier

3 Westinghouse Savannah River

Company

P. O. Box 616

Aiken, SC 29802

Attn: E. W. Holtzscheiter

D. K. Peeler

G. W. Wicks

1 Catholic University of America

Vitreous State Laboratory

Washington D.C. 20064

Attn: Ian L. Pegg

1 Dr. Harry Babad

2540 Cordoba $\mathrm{Ct}$

Richland, WA 99352

1 Dr. Etienne Vernaz

Commissariat à l'Énergie Atomique

Rhône Valley Research Center

BP 17171

30207 Bagnols-sur-Cèze cedex

FRANCE
No. of

Copies

1

Dr. Werner Lutze

Department of Chemical and Nuclear

Engineering

The University of New Mexico

Albuquerque, NM 87131

1 Dr. Bernd Grambow

Professeur de Radiochimie

Ecole des Mines de Nantes

Laboratoire SUBATECH

(UMR 6457)

La Chantrerie

4, rue Alfred Kastler

BP 20722

44307 Nantes cedex, 3

FRANCE

\section{ONSITE}

$4 \quad$ U.S. Department of Energy Richland Operations Office

N. R. Brown, H6-60

P. E. Lamont, H6-60

C. A. Babel, H6-60

Public Reading Room, H2-53

4 Fluor Federal Services

R. Khaleel, B4-43

R. J. Puigh, B4-43

$3 \quad$ CH2M Hill

F. M. Mann, H0-22 (2)

C. N. Wilson, H4-02 
PNNL-13043, Rev. 2

\section{DISTRIBUTION}

No. of

Copies

$29 \quad$ Pacific Northwest National Laboratory

D. H. Bacon, K9-33

M. P. Bergeron, K9-36

M. J. Fayer, K9-33

J. P. Icenhower, K6-81 (2)

P. F. Martin, P8-37

B. P. McGrail, K6-81 (10)

P. D. Meyer, BPO

D. R. Rector, K7-15

E. A. Rodriguez, K6-81

H. T. Schaef, K6-81

R. J. Serne, K6-81

J. L. Steele, K6-81

J. D. Vienna, K6-24

Information Release Office, K1-06 (7) 